\title{
Factors Regulating the Activity of LINE1 Retrotransposons
}

\author{
Maria Sergeevna Protasova $1, * \mathbb{D}$, Tatiana Vladimirovna Andreeva ${ }^{1,2} \mathbb{D}$ and Evgeny Ivanovich Rogaev $1,2,3,4, *$ \\ 1 Laboratory of Evolutionary Genomics, Department of Genomics and Human Genetics, Vavilov Institute of \\ General Genetics, Russian Academy of Sciences, 119333 Moscow, Russia; andreeva@rogaevlab.ru \\ 2 Center for Genetics and Genetic Technologies, Faculty of Biology, Lomonosov Moscow State University, \\ 119192 Moscow, Russia \\ 3 Center for Genetics and Life Science, Department of Genetics, Sirius University of Science and Technology, \\ 354340 Sochi, Russia \\ 4 Department of Psychiatry, UMass Chan Medical School, 222 Maple Ave, Reed-Rose-Gordon Building, \\ Shrewsbury, MA 01545, USA \\ * Correspondence: protasova@rogaevlab.ru (M.S.P.); evgeny.rogaev@umassmed.edu (E.I.R.)
}

Citation: Protasova, M.S.; Andreeva, T.V.; Rogaev, E.I. Factors Regulating the Activity of LINE1 Retrotransposons. Genes 2021, 12 , 1562. https://doi.org/10.3390/ genes12101562

Academic Editor: Albert Jordan

Received: 13 August 2021

Accepted: 22 September 2021

Published: 30 September 2021

Publisher's Note: MDPI stays neutral with regard to jurisdictional claims in published maps and institutional affiliations.

Copyright: (C) 2021 by the authors. Licensee MDPI, Basel, Switzerland. This article is an open access article distributed under the terms and conditions of the Creative Commons Attribution (CC BY) license (https:// creativecommons.org/licenses/by/ $4.0 /)$.

\begin{abstract}
LINE-1 (L1) is a class of autonomous mobile genetic elements that form somatic mosaicisms in various tissues of the organism. The activity of L1 retrotransposons is strictly controlled by many factors in somatic and germ cells at all stages of ontogenesis. Alteration of L1 activity was noted in a number of diseases: in neuropsychiatric and autoimmune diseases, as well as in various forms of cancer. Altered activity of L1 retrotransposons for some pathologies is associated with epigenetic changes and defects in the genes involved in their repression. This review discusses the molecular genetic mechanisms of the retrotransposition and regulation of the activity of L1 elements. The contribution of various factors controlling the expression and distribution of L1 elements in the genome occurs at all stages of the retrotransposition. The regulation of L1 elements at the transcriptional, post-transcriptional and integration into the genome stages is described in detail. Finally, this review also focuses on the evolutionary aspects of L1 accumulation and their interplay with the host regulation system.
\end{abstract}

Keywords: LINE-1 retrotransposons; L1 silencing; repetitive elements; regulation

\section{Introduction}

Dispersed DNA repeats of LINE-1 (L1) retrotransposons account for $17 \%$ of the human genome [1]. Most of L1, which includes more than 500 thousand copies, is not active in the genome as they are truncated repeats or contain mutations in the protein-coding sequence necessary for retrotransposition [2]. However, approximately 150 copies are full-length and capable of self-copying and distributing in the genome [3-5]. Moreover, L1 elements provoke the spread of other genetic repeats, such as Alu and SVA [6-8]. Insertions of L1 elements occur mainly in the non-coding regions of the genome: introns and intergenic spaces [9]. The presence of the L1 element at a certain locus can affect gene expression and even lead to the formation of alternative transcripts, which can make a significant contribution to the functions of individual cells, tissues, and the whole organism [10,11]. Regulation of L1 is a complex process in which a large number of genetic factors are involved. This review summarizes the data on molecular genetic factors involved in the regulation of L1 elements and their effect on various stages of the retrotransposition process.

\section{L1 Structure}

A full-length L1 copy is about $6 \mathrm{kbp}$. It contains a bi-directional promoter in the $5^{\prime} \mathrm{UTR}$; two open reading frames, namely ORF1 and ORF2, and a $3^{\prime} \mathrm{UTR}$ with a polyadenylation signal (polyA) (Figure 1) [12-14]. ORF1 encodes a $\sim 40 \mathrm{kD}$ protein with the chaperone activity necessary to stabilize a new L1 copy [15-18]. ORF2 encodes $\sim 150 \mathrm{kD}$ proteins with the endonuclease and retrotransposase activity required for the retrotransposition 
process $[15,19,20]$. In the opposite direction, ORF0 and two antisense promoters are located in the $5^{\prime}$ and $3^{\prime}$ UTR. The function of ORF0 remains poorly understood. According to some data, ORF0 is involved in the formation of chimeric proteins or enhances the mobility of L1 [13,21-23].

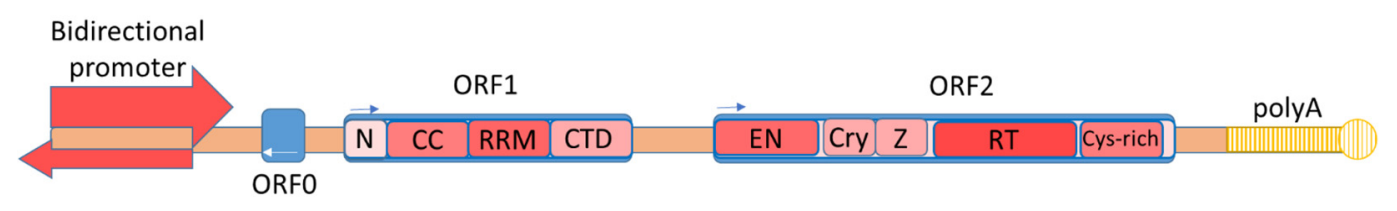

Figure 1. The structure of a full-length copy of L1 retrotransposon. ORF1 consists of an N-terminal domain (N), a coiled-coil domain (CCD), an RNA recognition motive (RRM), and a C-terminal domain (CTD) [18]. ORF2 consists of endonuclease (EN), retrotransposase (RT), a cryptic domain (Cry), a Z-domain (Z), and a C-terminal domain with a cysteine-rich region (Cys-rich) [24].

\section{Retrotransposition Mechanism}

L1 is distributed in the genome via the target-site primed reverse transcription (TPRT) mechanism (Figure 2) $[20,25,26]$. A new RNA copy of the L1 element is expressed from the forward chain of the L1 element due to the strong promoter in the $5^{\prime}$ UTR [14,27]. The new copy is then polyadenylated and leaves the nucleus [28]. Translation of ORF1 and ORF2 as well as the formation of L1 ribonucleoprotein (L1 RNP) occur in the cytoplasm. L1 RNP is a bicistronic mRNA coated with ORF1 proteins and contains one or two copies of the ORF2 protein [29]. In the cytoplasm, polyadenylate-binding protein 1 (PABPC1) attaches to the polyA tail of L1; its presence is critical for the formation of L1 RNP [28]. Transportation of L1 RNP from the cytoplasm to the nucleus is accomplished using the membrane-associated endosomal sorting complex required for transportation (ESCRT) [30]. It has also recently been shown that the ORF1 protein interacts with the KPNA2 and KPNB1 karyopherins, as well as possibly other KPNA family proteins involved in nuclear protein importation through nuclear pores (nuclear pore complex) [18]. The cancer cell model showed that L1 RNP penetrates the nucleus during mitosis and the integration of the new copy of the L1 element into the genome occurs in the S phase of a cell cycle [31]. Interestingly, in different tissues, the association of the L1 retrotransposition process with certain stages of the cell cycle can be different. For example, in neuronal cell cultures, it has been shown that retrotransposition can occur in non-dividing cells [32]. In entering the nucleus and reaching the genomic DNA, the endonuclease recognizes the concensus cleavage site $5^{\prime}$-TTTT / AA-3 ${ }^{\prime}$ [20,33-35], and creates a single-stranded DNA break with the formation of both phosphate 5'-PO4 and hydroxyl 3'-OH groups at the ends [20]. The $\mathrm{L} 1$ transcript is attached via the polyA tail to the region of the endonuclease recognition site and reverse transcription of the L1 RNA occurs [36-38]. For the classical mechanism of retrotransposition, host proteins involved in DNA repair and replication are necessary $[34,39,40]$. A complex of PARP1 and PARP2 proteins is formed at the single-strand DNA breaks [40]. PARP2 specifically recognizes a single-stranded DNA gap at the L1 integration site. PARP2 is activated by the poly-ADP ribosylation process (PARylation). Activated PARP2 interacts with the RPA complex, which allows for the integration of a new synthesized L1 copy into the DNA. RPA, a replicative complex of protein A (heterotrimeric protein A complex), consisting of RPA70, RPA32, and RPA14 proteins, is required to bind single-stranded DNA in eukaryotes and to protect it from the deamination of cytidine [41]. The role of PARP1 in L1 retrotransposition has not been fully understood but it has been revealed that PARP1 interacts directly with ORF2, and the retrotransposase domain is responsible for this process. The absence of one of the PARP1 or PARP2 proteins leads to a decrease in the retrotransposition by about $50 \%$; the absence of both proteins or the RPA complex reduces L1 retrotransposition by $80 \%$ [40]. The ORF2 complex, which is formed in the region of integration into the genome and promotes reverse transcription, includes various proteins involved in DNA stabilization and enzyme processability [42]. 
The first of these proteins is the proliferating cell nuclear antigen factor (PCNA). ORF2 interacts with PCNA and this interaction is critical for retrotransposition [43]. RUVBL1 and RUVBL2 repair proteins are also required for L1 spreading and their absence leads to a decrease in the retrotransposition [43]. In addition, the nonsense-mediated decay factor UPF1 and the MOV10 helicase were detected in the L1 RNP. Interestingly, UPF1 knockdown increases the amount of mRNA and L1 proteins but simultaneously reduces the effectiveness of the retrotransposition [43]. Inhibitory activity against L1 was shown for MOV10. However, in a recent study, it was suggested that MOV10 may facilitate the attachment of UPF1 to L1 RNP [42,44]. Insertion of the full-length L1 copy is a rare event; usually, a new copy of the L1 element is truncated from the $5^{\prime}$ UTR [26,45-47]. Doublestranded DNA repair factors XRCC6 (Ku70/Ku80), Artemis (DCLRE1C), and LigIV (LIG4) are involved in the truncation of a new copy of the L1 element [46] (Figure 2). The exact mechanism of their action remains unclear. It is suggested that XRCC6 can facilitate the attachment of ORF2 to the overlying targeted DNA, thus accelerating the completion of the retrotransposition process and leading to truncation [46]. After integration of the reverse complement strand of the new L1 copy, the second strand of DNA breaks and the first strand of the new L1 copy is synthesized using the host cellular enzymes involved in both DNA replication and reparation $[34,40]$. Retrotransposition can occur using an alternative endonuclease-independent (EN-independent) mechanism in p53-defective cells or cells containing mutations in the non-homologous end-junction (NHEJ) genes during DNA repair, which apparently uses DNA breaks to initiate transcription [45,48-50].

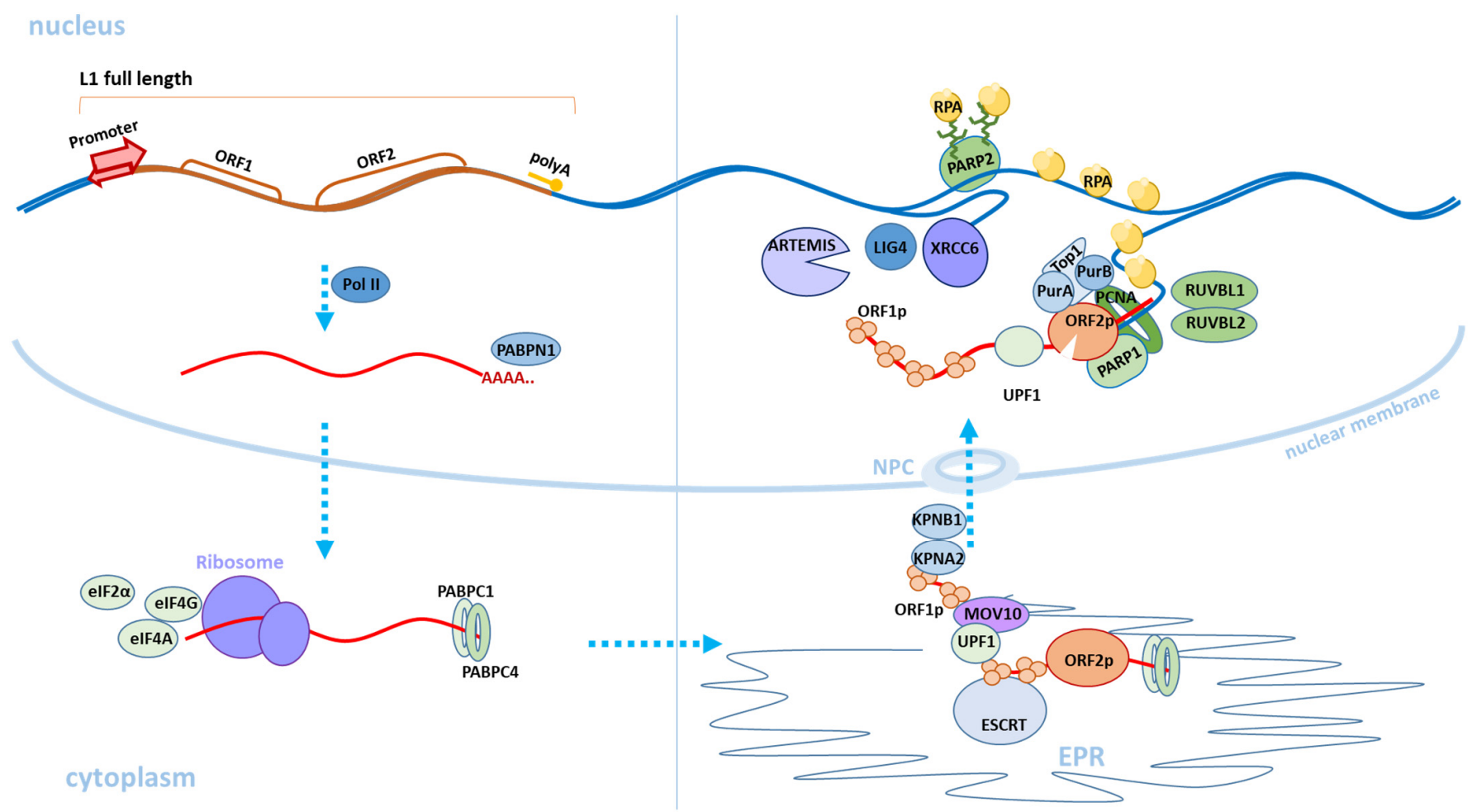

Figure 2. Scheme of the classical retrotransposition mechanism of L1. The transition of L1 from one stage of retrotransposition to another is indicated by blue dashed arrows. The upper left part of the figure shows the expression of a full-length copy of active L1 in the cell nucleus. The L1 RNA transcript (marked in red) is transported to the cytoplasm. The L1 ORF1p and ORF2p proteins are synthesized and the L1 RNP is formed (in the lower right part of the figure). Then, through the endoplasmic reticulum (EPR) and nuclear pore complex (NPC), L1 RNP is transported to the nucleus and L1 DNA copy formed by a reverse transcription is integrated into a new genomic locus (in the upper right part of the figure). The cellular factors involved in the retrotransposition process, which are described in this review, are also depicted. 


\section{L1 Evolution}

L1s belonging to the LINE class of mobile genetic elements are found in the genomes of animals and plants [51,52]. Although animal L1 is found in the genomes of some protostomes, the history of gradual accumulation and the evolution of modern L1s can be traced at the level of deuterostomes, possessed by three highly divergent groups: a united species from echinoderms to teleost fishes; non-mammal vertebrates; vertebrates from fish to mammals $[52,53]$.

\subsection{LINE Evolution in Deuterostomes and Non-Mammals}

A high diversity of ancient L1 families was found in the lancelet, sea urchin, and tunicates, and despite their variability, they make up a small proportion of the repeated sequences [53,54]. Mobile elements are in constant competition with each other and with factors limiting their activity in the cell, and they try to maintain the ability to spread in the genome and increase the number of copies by capturing new genomic loci. However, this battle is not always successful considering that in most bony fish genomes, although there are exceptions, the number of LINEs is not large compared to other mobile elements, yielding to DNA transposons [54-56]. On the contrary, in the known representatives of living jawless fishes, cartilaginous fish, coelacanths, and lungfishes, the number of LINEs is not inferior to other classes of DNA repeats and constitutes 25$50 \%$ of all repeats in the genome [54,57-62]. Interestingly, increased diversity of the L1 families is observed in fish [53]. Moreover, the highest diversity of L1 was found in African coelacanth. Nonetheless, the most successful LINEs in this group are still CR1 and L2 [56]. A high diversity of L1 was observed in amphibians, although, similar to that in bony fish, the number of LINEs remains small and most of them are either DNA transposons or LTR $[53,54,58]$. In reptiles, except green anole, several LINE families (CR1, BovB, L2) are evolutionarily successful, the activity of which continues to persist in the genomes, and their amount increases relative to other repeats [55,63-68]. The genome of tuatara is distinguished by a variety of repeats in which L2 is the most successful group [68]. The most widespread CR1, completely displacing L1, is in the genomes of turtles, crocodiles, and birds. The success of these elements was facilitated by the highly conserved hairpin structure and octameric microsatellite motif at their $3^{\prime}$ UTR $[65,69-71]$. In the avian genomes, there was a sharp decrease in the genome size and number of repeated sequences. LINE/CR1 are the remaining bulk [71].

\subsection{LINE Evolution in Mammals}

In mammals, many LINEs lost the ability to spread due to various mutations and truncations of full-length copies [64,72]. Only one family of LINEs remains active. The most successful group of mobile elements in mammals is L1. An exception is the group of monotremes, which have no L1 sequences [52]. Thus, in platypus, L2 is the most prevalent of LINEs [73]. Metatheria (marsupials) and eutheria (placental mammals) have similarities in the composition and evolutionary tendencies of their mobile elements. In the genomes of most mammalian species, L1 becomes the most successful and active group, while many ancient repeats gradually disappear from the genome in process of evolution.; Intrestingly, that some enhancers and ultra-conserved elements are originated from ancient retrotransposon repeats $[55,74,75]$. Active L1s are species-specific genomic elements. Nevertheless, their structure is similar in all mammals and the greatest differences involve the non-coding region 5'UTR, the size of which varies greatly in different species [64]. 5'UTR changes play an important role in the interaction with cellular transcription factors that regulate L1 expression. Of the L1 encoded proteins, ORF1 differs in variability, while ORF2, on the contrary, is conservative [64]. Differences and evolutionary trends of L1 elements in mammals have been described in some animal groups. For example, some bats, similar to flying birds, have a decrease size of genomes and are characterized loss of active L1 elements [71,76]. The L1 extinction is also observed in certain mammalian species that are not adapted to 
flight. The disappearance of L1 activity was noted for Spermophilus tridecemlineatus from the superorder Afrotheria, perissodactyls, and sigmodontine rodents [77-80].

L1 is active in rats and mice. However, the accumulation and activity of mobile genetic elements of the widely studied mouse (Mus musculus) differ from the general tendencies of mammals, including humans and other primates, because LINE elements are quantitatively inferior to LTR repeats in its genome [81]. However, L1 makes up about $20 \%$ of the murine genome and L1Md is currently active. LINEs account for about $23 \%$ of the rat genome [82]. In addition to the traditional L1, the rat genome acquired the activity of HAL1 (HALFL1) elements, the shorter version of L1 elements. In follow up the integration into the genome the HAL1 elements retain their internal promoter, that is othen truncated in case of integration of full-length L1 elements.

\subsection{LINE Evolution in Primates}

Primates separated from other ancestral mammals about 90-65 million years (myrs) ago and are characterized by the distribution of the L1PA-L1PB families [83-85]. Comparative evolutionary analysis of L1 revealed different trends in discrete primate species [86]. In most primate species, L1 is the most active family capable of self-propagation in the genome, as well as the most capable of contributing to the amplification of SINE elements, the copy number of which in genomes reaches the maximum of all dispersed repeats. In most species of New and Old World primates, the L1 remains active. Only in New World South American spider monkeys the absence of L1 activity was found [87,88]. The evolutionary history of the Old World primates began approximately 21-25 myrs and is associated with the distribution of L1PA6-L1PA5 elements [83,89-91]. L1PA5-6 elements, which are evolutionarily closest to their modern active L1 subfamilies, are most widely distributed in the genomes of monkeys (Cercopithecoidea) [89,90]. Interestingly, the greatest differences in the number of primate L1 were found among the Cercopithecoidea. For example, the baboon has the highest L1 amplification rates in the genome compared to other primates. On the contrary, the green macaque has the lowest number of L1 repeats compared with other primates [86].

The branch of great apes split off about 26 myrs ago [92]. Among the great apes, the largest number of L1 insertion loci was found in the orangutan. Moreover, the number of LINEs in orangutan genome significantly dominates over other families of dispersed DNA repeats, while in other primates, SINE insertions are most common [86]. Compared to other primates, the number of LINE insertions in humans is not large. However, the largest number of currently active LINE elements was found in the human genome [86]. Thus, the gorilla genome harbors twelve intact full-length gorilla-specific L1s belonging to the L1PA2 subfamily [93]. In chimpanzees, L1Pt-2 are active and only nine copies are full-length elements with intact ORFs [94]. In contrast, in humans, the active family is the L1HS, consisting of several subfamilies, namely pre-Ta, Ta-0, Ta-1, Ta1-d, and Ta1-nd [9,95], of which about 146 copies are active [5]. Moreover, comparative analysis showed that the activity of human L1 copies is significantly higher than that of chimpanzees $[90,94]$.

\subsection{LINE Evolution in Ancient and Modern Humans}

A number of studies have shown that the accumulation of loci containing L1 repeat insertions is not random but occurs in accordance with functional significance. Thus, L1 insertions are more often retained in the trans-orientation relative to the gene, while insertions in the cis-orientation are washed out from the genome $[96,97]$. The evolutionary trends of L1 in the Homo branch are of great interest. However, the genomic architecture of L1 elements in ancient humans (Homo sapiens sapiens) and related subspecies, ancient hominids, (Neanderthals and Denisovans) are poorly understood due to the difficulties of genomic mapping of repeat elements using short reads available from the sequencing of ancient DNA. Nevertheless, several studies carried out an analysis of the mobile elements, which showed the presence of introgression of the L1 insertion loci of ancient people in the DNA of modern people, the nature of which corresponds to the same for SNV [98,99]. 
Moreover, in the genomes of ancient hominids, the sequences corresponding to the most active L1Ta1d mobile elements of the modern human genome were determined. Thus, the origin of L1Ta1d could have occurred in the common ancestor of ancient hominids and modern humans more than 800 thousand years ago [98]. An analysis of the insertion loci in genes in ancient people and modern humans showed that most of the repeat insertion loci specific to modern humans, including L1, originated in the genes that are highly expressed in the brain and are involved in neuronal maturation [99].

Analysis of L1 insertions in modern world human populations of the Phase3 data release project 1000 Genomes, which included 2.5 thousand individuals from 26 populations, reveals 2.91 thousand polymorphic L1 loci [100]. It was found that the majority (over 93\%) of the identified loci of active retrotransposons (L1, Alu, and SVA) have a low population frequency of less than $5 \%$. Moreover, such lowfrequency of insertion loci have substantial geographic differentiation. In support of this, in a recent study with a significantly smaller number of individuals (296 individuals) but greater population diversity (146 populations) from the Simons Genome Diversity Project (SGDP), a relatively large number of 1.886 thousand polymorphic unreferenced L1 loci were identified [101]. In both studies, the number of L1 polymorphic loci is 6-10 times lower than the Alu polymorphic loci but exceeds 3.5-4 times the number of SVA element polymorphic loci. The polymorphism of the insertion loci of active retrotransposons reflects the evolutionary aspects of modern populations and the migration processes of the world [100,101]. The greatest diversity is observed in Africans who are evolutionarily basal in world populations [100,101]. A decrease in heterozygosity is observed in populations of Eurasia and a minimum value was found in Native Americans [101].

\subsection{LINE Evolution and Host Regulation}

The L1 regulatory factors are evolved along with evolution of L1 elements. APOBEC3 protein family and the Piwi-interacting RNA (piRNA)-signaling pathway are involved into the cellular defense mechanisms against the uncontrolled spread of L1 (see Regulation of L1 Activity). One of the most susceptible proteins to strong evolutionary selection, amplification, and divergence in mammalian genomes is the APOBEC 3 subfamily of antiviral factor genes [102,103]. High divergence of $A P O B E C 3$ was noted in the genomes of bats and primates [104-106]. Interestingly, other closely related genes belonging to the AID/APOBEC family have lower evolutionary rates in mammals [107]. High evolutionary rates are also observed for the piRNA pathway, many genes of which are under the influence of positive selection [108]. The different regulatory pathways capable to repress L1 elements have been evolved reflecting the constant battle between mobile elelements and the cellular host defence [109-111]. The difference in expression of genes involved in host defence pathways of mobile elements between animal species plays an important role in the effectiveness of L1 inhibition. As shown in one study, there is a higher expression level of $A P O B E C 3 B$ (also known as $A 3 B$ ) and PIWIL2 genes in human pluripotent stem cells, compared to the closest non-human primates (Pan troglodytes and Pan paniscus). The study showed that L1 silencing in human cells is more efficient as compared to chimpanzee cells [112].

Further, the factors regulating L1 elements are considered in detail.

\section{Regulation of L1 Activity}

The process of the regulation of L1 activity throughout ontogenesis is complicated. In most cells, L1 activity is inhibited at all stages of the retransposition process in various ways: by decreasing the availability of DNA using DNA methylation $[110,113,114]$, histone modifications, and heterochromatin formation $[110,115,116]$; through post-transcriptional inhibition by degradation of new RNA copies of L1 [117,118]; through repression of ORF1 and ORF2 translation; through the binding of L1 RNPs and the obstruction of their transportation to the nucleus [119-122]; and, at the last stage of integration for a new copy of the L1 element into the genome, through using DNA repair mechanisms [120,123-126] 
(Figure 3). In the process of organism ontogenesis, changes in the regulation of L1 activity occur. Thus, at the stage of formation of germ cells and mature germ cells, L1 poses a great threat to the future organism and, therefore, is thoroughly repressed by cells $[127,128]$. Most experimental knockouts of factors involved in the L1-silencing in germ cells lead to their death and infertility [129]. In the early stages of embryogenesis, activity of L1 is also dangerous for the developing organism and, therefore, is repressed [130-132]. Some changes occur in the pathways of L1 repression during embryogenesis and the activity of L1 elements increases at certain stages [133,134]. L1 elements are mainly repressed in somatic tissues of a mature organism, but increased L1 activity is noted for some pathologies including cancer as well as autoimmune and neuropsychiatric disorders [135]. With normal ageing, changes in the number of insertions of L1 are insignificant [136]. However, in some tissues, especially in the brain, L1 is not completely suppressed and L1 retrotranspositions can be activated [137-139].

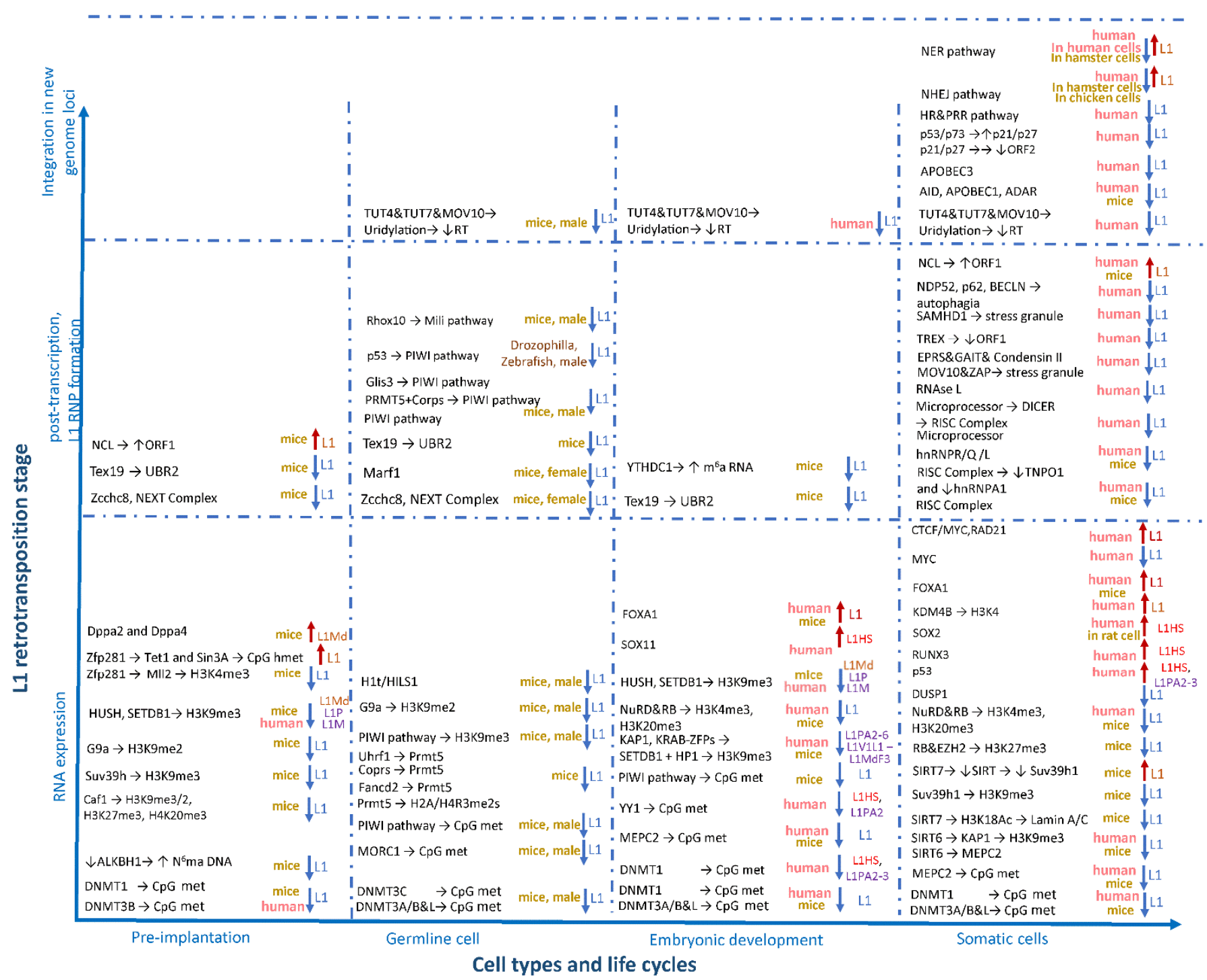

Figure 3. Factors affecting the activity of L1 retrotransposons during ontogenesis. The factors involved in L1 regulation are grouped horizontally in accordance with the stages of prenatal development (pre- and post-implantation period and in germline cells) and the postnatal period (somatic cells), as well as vertically depending on the stage of the retrotransposition process (expression, L1 RNP formation, and integration into the genome). 


\subsection{Regulation of L1 in the Early Stages of Embryogenesis}

The regulation of the $\mathrm{L} 1$ element activity in germ cells and during embryogenesis has been most thoroughly studied on model objects such as mice (Figure 3). DNA methylation is one of the main mechanisms of epigenetic regulation in the genome. Methylation during embryogenesis is provided by the methyltransferases DNMT1 and DNMT3B, the knocking out of which leads to the death of mouse embryos $[140,141]$ and human embryonic cultured cells [114]. DNA methylation undergoes changes during the process of embryonic development. The highest methylation level in mice is observed at the zygote formation stage, after which the first short-term decrease in methylation DNA level occurs, the minimum of which is reached at the 8-cell embryo stage [133]. It has recently been shown that global DNA hypomethylation during this period supplies the factors Dusp6 and Corp1 [142]. According to some data, at the stage of the preimplantation embryo, mice showed high levels of expression of various retrotransposons, particularly L1, the peak expression of which falls on the 2-cell embryo stage, after which the expression decreases [143-145]. However, an increase in the number of new L1 insertions was not detected during the experiment [145]. Recently, the paralogous transcription factors DPPA2 and DPPA4 have been shown to stimulate the expression of the active L1 families (L1Md_T and L1Md_A) and the Dux gene (MERVL repeat transcription factor) in mice at the 2-cell embryo stage [134]. The lack of DPPA2 and DPPA4 leads to the loss of the active chromatin marker H3K4me3 and gain de novo DNA methylation of developmental genes and young L1 [142]. At present, it is not known what function L1 performs at this early stage in the development of the organism. According to some reports, activation of L1 expression may affect chromatin availability and is necessary for the transition from the 2-cell embryo stage to the 4-cell embryo stage [145]. The interaction of L1 with nucleolin and Kap1/Trim28 leads to the inhibition of the transcription factor Dux and to increased expression of rRNA [146].

However, the L1 activation is short-term. In hypomethylated preimplantation mouse embryos, the inhibition of different families of retrotransposons occurs by histone methylation H3K9me3, H3K9me2, H3K27me3, and H4K20me3, mediated by histone chaperone chromatin assembly factor 1 (Caf-1) [115]. The knockout of this factor leads to the activation of various retrotransposons before the formation of the blastula and to the death of embryos at the morula stage [115]. In a recent study, the authors identified a total of 29 chromatin markers involved in the repression of retrotransposons in a murine embryonic stem cell culture [116]. For active L1 (L1Md), the highest enrichment with several histone markers was revealed including repressive (H3K9me3 and $\mathrm{H} 3 \mathrm{~K} 9 \mathrm{me} 2)$ and activating (H3K9ac9 and H3K56ac) modified histones [116]. To date, several methyltransferases have been identified that are involved in the histone methylation in the region of retrotransposons in murine embryonic stem cells. Arginine N-methyltransferase Prmt5 plays an important role in the repression of retrotransposons in primordial germ cells and in preimplantation embryos in mice. Despite repression of L1 in germ cells, in mouse preimplantation embryos, Prmt5 implements the control of IAP elements by histone methylation H2A/H4R3me2s, migrating from cytoplasm to the nucleus during the period of 2.5-3.5 embryonic days (E2.5-3.5) [130]. Methylation of H3K9 histones is carried out independently from each other using methyl transferases Suv39h, G9a, and SETDB1 [147-150]. G9a plays an important role in the mono and dimethylation of $\mathrm{H} 3 \mathrm{~K} 9 \mathrm{me} 1 / \mathrm{me} 2$ histones at an early stage of embryo development and germ cells, and its knockout leads to the death of mouse embryos between E9.5 and E12.5 [148]. Suv39h performs trimethylation of $\mathrm{H} 3 \mathrm{~K} 9 \mathrm{me} 3$ histones directly in the regions of the L1 and ERV promoters [147]. There are two Suv39h1 and Suv39h2 genes in the mouse and human genomes that replace one another, and only double knockout of the genes leads to mortality after E12.5 [151,152]. Methyltransferase SETDB1 is mainly involved in the repression of IAP mice $[149,150]$. However, regulated by the factor TRIM28, SETDB1 also represses certain families of murine L1: L1V1L1-L1MdF3 families of origin age of approximately 5.57-3.77 myr [109]. Repression of active evolutionarily young copies of L1 (as well as copies inactive and older than $13 \mathrm{myr}$ ) in mice is carried out using the regulatory complex HUSH. The HUSH complex consists of three proteins, namely TASOR, MPP8, 
and Periphilin, that promote the formation of $\mathrm{H} 3 \mathrm{~K} 9 \mathrm{me} 3$ histones methylation and the formation of heterochromatin $[153,154]$. The lack of the TASOR component of the HUSH complex leads to the death of mouse embryos before the completion of gastrulation [155]. Silencing of mobile elements can also occur due to a decrease in the number of markers of active chromatin. Thus, histone methylation of active marker H3K4me3 is provided by Ml12 methyltransferase, which is regulated by the transcription factor Zfp281 [156]. To repress active repetitive elements, Factor Zfp281 restricts Mll2 through regulating the activity of Tet1 and Sin3A hydroxymethylases in L1 promoter regions [156]. In addition to DNA methylation and histone methylation, a decrease in L1 expression and the formation of heterochromatin in mammals is facilitated by another evolutionarily ancient method of DNA modification: N6-methyladenilation [157,158]. A study in mice revealed that this marker suppresses L1 in mouse embryonic stem cells [159]. Marker N6-methyladenine is located mainly in areas of young L1 (<1.5 Ma). The presence of this marker leads to their inactivation. A deficiency of the N6-methyladenine demethylase enzyme, ALKBH1, leads to transcriptional inhibition [159]. At the post-transcriptional level, RNA transcripts can also be labeled with N6-methyladenosine, leading them to be silenced [160]. This manner of transcript inhibition can be used by mouse embryonic cells to repress LINE1 and other retrotransposons (IAP, ERVK, etc.) [161,162]. A lack of YTHDC1, a factor that initiates silencing by recognizing N6-methyladenosine modification and transcript binding, leads to the transition to the 2-cell embryo stage [161,162]. Post-transcriptional degradation of L1 in early embryos can occur due to the nuclear exosome targeting (NEXT) complex, the central factor of which is Zcchc8 [131]. Knockout of the Zcchc8 factor in mice increases chromatin availability and L1 expression, resulting in impaired blastula formation and decreased survival of homozygous knockout mice [131].

\subsection{Regulation of L1 in Germ Cells in Mice}

The formation of primordial germ cells (PGS) in mice occurs on E7.25 (Figures 3 and 4) [163-167]. In PGS, DNA undergoes global demethylation, which occurs on day E8.5 of embryogenesis and lasts until E13.5, when PGS are grouped into the genital ridge [168-171]. Demethylation leads to activation of IAP repeats, however, L1 remains silent at these stages [170]. After E13.5, the methylation profile of male and female germ cells is different [171]. In mice male germ cells, DNA methylation occurs due to Dnmt3A and 3B DNA methyltransferases, as well as due to the Dnmt3L protein, which does not have enzymatic activity but is an important auxiliary factor [172,173]. De novo methylation of evolutionarily young L1 and IAP families occurs using Dnmt3C, which is a duplicated copy of Dnmt3B in the rodent genome [174,175]. Methylation is initiated shortly after E13.5 and peaks after the birth [176]. The remethylation of L1 in male germ cells occurs briefly from E12.5 to E15.5 [132,177,178].

One of the most studied mechanisms of L1 inhibition in male embryonic germ cells is the mechanism that involves the Piwi-interacting RNA (piRNA)-signaling pathway, acting at the transcriptional and post-transcriptional levels [179-181]. piRNAs are small non-coding RNAs, 24-32 bp long, that specifically bind to the Argonaute proteins of the PIWI subfamily [182,183]. The PIWI family of proteins interacting with piwiRNA includes four proteins, namely PIWIL1-PIWIL4. Only three proteins are present in mice: Miwi (PIWIL1), Mili (PIWIL2), and Miwi2 (PIWIL4). In contrast, in humans, there are all four proteins: HIWI (PIWIL1), HILI (PIWIL2), HIWI2 (PIWIL4), and HIWI3 (PIWIL3) [184]. L1 degradation in hypomethylated embryonic germ cells can occur through direct interaction with the piRNA-PIWI complex with the new L1 RNA copy and its subsequent degradation. The piRNA-PIWI complex can also mediate DNA methylation. This complex is Miwi2-piRNA in the mice embryonic male germ cells $[180,185,186]$. Moreover, the piRNA/PIWI-signaling pathway is necessary to maintain a high level of H3K9me3 histone repression modifications in L1 regions [179]. Damages in many genes involved in the piRNA/PIWI-signaling pathway (including Mili and Miwi2) are associated with L1 activation of retrotransposons, impaired cell formation, and infertility. As previously mentioned, 
Prmt5 is involved in the inhibition of retrotransposons, including L1, in PGS $[130,187]$. The control of the epigenetic regulation of Prmt5 occurs using two pathways: (1) the methylation of histones $\mathrm{H} 2 \mathrm{~A} / \mathrm{H} 4 \mathrm{R} 3 \mathrm{me} 2 \mathrm{~s}$ in the nucleus and (2) the enzyme entrance into the cytoplasm and activation of the piRNA/PIWI-signaling pathway [130]. In PGS, during the E8.5-10.5 period, Prt5 methyltransferase is located in the nucleus, participating in the methylation of histones H2A/H4R3me2s in the regions of IAP and L1 elements [130]. Then, at approximately E11.5, the Prmt5 enzyme migrates into the cytoplasm and provides arginine methylation in Piwi proteins, which is necessary for binding to proteins containing the Tudor domain [187]. Prmt5 knockout in PGS results in complete sterility of the female and male individuals [130]. Recently, Prmt5-dependent histone methylation has been shown to be catalyzed by the Fancd 2 factor, one of the most important factors for homologous DNA recombination and repair involved in the suppression of L1 in somatic tissues [188]. Knockout of the Fancd2 factor leads to a decrease in Fancd2-catalyzed H2A/H4R3me2s markers in the L1 region at E10.5 [188]. Additionally, Corps factor (Copr5) is required to activate Prmt5 $[189,190]$. In mice PGS, Mili protein expression begins from E12.5 and lasts the longest until around the spermatid stage in adult testicles [190,191]. Mili is located mainly in the cytoplasm and is required for the primary processing of piRNA, secondary piRNA biogenesis, the ping-pong cycle, de novo DNA methylation, and posttranscriptional inhibition of L1 retrotransposons [180,192]. Along with Mili, Mov10L1 [193], Tdrd1 [194], and Tdrkh (Tdrd2) [195] are also involved in the primary processing of piRNA, for which it is well shown that their defects lead to L1 activation, arrest of meiosis, and sterility. A recent study has shown that the factor of positive regulation of Mili is the Rhox10 transcription factor [196]. Although the Rhox10 gene is present only in the genomes of mice, the contribution of the Rho family to the regulation of Piwil2 is evolutionarily conservative according to the authors of the publication [196]. In the interval between E12.5 and 13.5 in mice, during hypomethylation, the testis-specific transcription factor Glis 3 is activated. This factor provides the inhibition of various retrotransposons, especially L1 and IAP [197]. During late embryonic development and in the first few days after birth, E15.5-P3, expression of Miwi2 is observed, the protein complex of which induces de novo DNA methylation that inhibits the spread of L1 $[180,185]$. In addition, Miwi2 provides trimethylation of the H3K9me3 histones of active full-length L1 and LTR elements [179]. Lesions in the genes Tdrd1 [194], Mvh [198], Tdrd12 [199], Fkbp6 [200], and Gtsf1 [201] lead to disruption of the complex formation and dislocation of Miwi2 from the nucleus to the cytoplasm, and also lead to the impairment of various retrotransposons and L1-silencing in the nucleus. The Exd1 factor interacts with Tdrd12 and, with its partial deficiency, also leads to both the disruption of Miwi2 biogenesis and activation of L1 [202,203]. Recently, it was shown that in the perinatal period (E16.5-18.5), the expression of factor Tex15 occurs, which affects the methylation of only active L1 and IAP retrotransposons. The exact role of factor Tex15 in such a short period of time is not completely clear. An absence of it does not disturb the biogenesis of piRNA but leads to a decrease in the expression of the Gtsf1 factor associated with both the Mili and Miwi2 proteins $[201,204]$. Regardless of the piRNA/PIWIsignaling pathway, the Morc1 factor regulates the methylation of retrotransposons from the late embryonic stages (after E14.5) to the first meiosis in male embryonic germ cells; a deficiency of this factor leads to demethylation of the L1 transcription initiation regions and to an increase in its expression at the E16.5 stage [205]. Morc1 deficiency also leads to the expression of other retrotransposons (LTR and IAP) [205].

In mature mice, L1 is inactive in the stem cells of the testes-spermatogonia but is active in spermatocytes [193]. L1 suppression in spermatogonia of mice is carried out using several mechanisms due to DNA methylation and the piRNA/Piwi-signaling pathway, as well as due to histone methylation. DNA methylation of the L1 promoter regions during the period of postnatal development and up to the stage of meiosis of primary spermatocytes is performed by the Morc1 factor. The onset of meiosis I in male germ cells is associated with epigenetic changes in the profile of DNA and histone methylation. In the first stages of meiosis during the period of leptotene and zygotene, methylation of 
histones H3K9me1/2, carried out by methyltransferase G9a, plays an important role in L1 repression [206]. In addition, Mili, which has the longest expression period in the pre and postnatal period, makes a large contribution to the repression of retrotransposons [192]. During this development period, the deficiency of one of the pathways is compensated by the other. An increase in L1 activity is observed only with the double knockout of G9a and Mili [206]. Mili is known to repress retrotransposons at the post-transcriptional level. Mili can also participate in DNA methylation in combination with Miwi2 in the prenatal period [180,207]. A recent study showed that Mili can interact with Tex15 and this is necessary for the methylation of retrotransposons in germ cells [204]. Additionally, from the beginning of the leptotene stage to the stage of round spermatids, the expression of Suv39h2 methyltransferase is observed, which is involved in the methylation of histone H3K9me3 [151,208]. Thus, a recent study showed the association of the histone of the H1t linker with repressive histone markers H3K9me3 and H4K20me3 in the region of L1 and LTR repeats, and suggested the participation of the piRNA/PIWI-signaling pathway in the formation of heterochromatin [209]. In an earlier study on rats, the presence of a spermatid-specific histone linker (HILS1) was also found, which promotes the formation of higher-order chromatin structures in L1 regions as well as the enrichment with histone markers H3K9me3, H4K20me3, H4K5ac, and H4K12ac [210]. At the beginning of meiosis I, at the stage of prophase I, a change in the localization of the Uhrf1 factor is observed. The Uhrf1 moves from the nucleus to the cytoplasm, where the factor arrives in the period from leptotene to early pachytene, and then migrates back to the nucleus [211]. The Uhrf1 factor is involved in the regulation of the epigenetic profile of both DNA methylation via DNMT1 and the formation of histone repression markers $\mathrm{H} 3 \mathrm{~K} 9 \mathrm{me} 3$ during mitosis interacting with various factors that modulate histones [211-214]. Recently, it was shown that at the prophase stage of meiosis I, Uhrf1 is necessary for the interaction with Prmt5 and activation of PIWI proteins at the pachytene stage, and its absence leads to the activation of L1 and AIP retrotransposons, resulting in a decrease in DNA and histone methylation, as well as a deficiency in the piRNA/PIWI-signaling pathway, leading to defective meiosis and sterility $[130,211]$. It has also recently been shown that in adult testicles, Corps is required for Prmt5 activation and its knockout leads to a decrease in Miwi and L1 activation, disrupting the maturation of spermatogonia in spermatids and leading to infertility [190]. At the pachytene stage, many factors participating in the piRNA/PIWI-signaling pathway begin to be expressed, including the Miwi protein, which is characteristic of mature testicles $[207,215]$. The lack of piRNA/PIWI-signaling pathway factors is reflected in the efficiency of L1 repression in testicles. Thus, the deficiency of the Pnldc1 and Tdrkh genes involved in the primary processing of piRNA leads to L1 depression and spermatogenesis defects [216-218]. It is worth noting that at the last stages of sperm maturation in mice, the L1 DNA methylation undergoes changes. A recent study showed that, starting from the round spermatid stage, the regions of active L1 promoters are enriched with 5-carboxymethylcitazines (5-caC), which are considered as a marker of active demethylation $[219,220]$.

Control of the retrotransposons activity in female germ cells is different from male germ cells. In the precursors of female germ cells, L1 demethylation occurs gradually starting from E10.5 to E15.5-17.5 [132,177]. Despite the expression of piRNA/PIWI-signaling pathway proteins in female germ cells, its deficiency does not affect the development of oocytes [221-223]. There is also a hypothesis that the absence of the piRNA/PIWI pathway can be compensated by the RNA interference pathway [224,225]. However, a recent study showed that the absence of both signaling pathways, although causing an increase in the number of L1, does not interfere with the development of female germ cells in mice [226]. Studies published in the last two years have shown that control of the L1 activity of female germ cells (oocytes) in mice is carried out at a post-transcriptional level that promotes the degradation of L1 transcripts (Figure 3). The first suppressor L1 was found as a factor of meiosis arrest female 1 (Marf1) in mice female germ cells [227]. Marf1 has ribonuclease activity and provides the degradation of single-stranded RNA, preventing the spread of 
retrotransposons [118]. It has also recently been shown that in oocytes, in mice, in the early embryonic stages, L1 inhibition occurs due to post-transcriptional degradation of RNA using the nuclear exosome targeting (NEXT) complex and the Zcchc8 factor [131]. The survival rate of maternal Zcchc8 knockout mouse embryos is reduced, the expression of L1 and MERVL is markedly increased at the 4-cell embryo stage, and only half of the embryos reach the blastocyst stage and continue to develop [131].

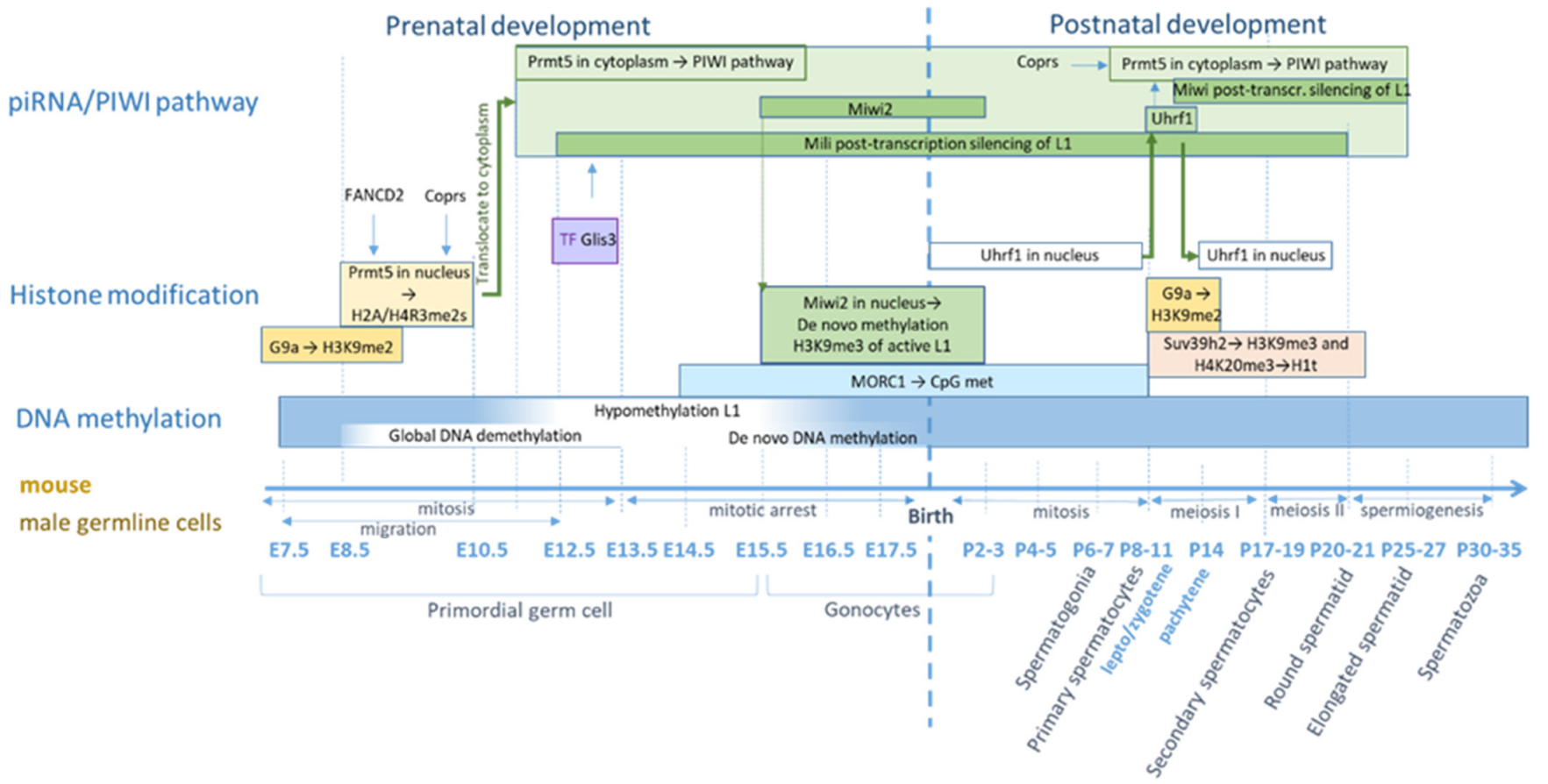

Figure 4. Scheme of L1 repression during the formation of male germ cells in mice. The factors involved in L1 restriction in male germ cells are depicted according to their activity at certain stages of pre and postnatal mouse development. The $X$-axis shows the age of the mouse and the corresponding types of male germ cells.

\subsection{Other Factors Controlling L1 in the Embryonic Development of Mice}

The list of factors in the regulation of retroelements in the process of embryonic development is constantly updated. Factor Tex19.1 and its paralogue Tex19.2 with a high level of expression in embryonic pluripotent cells, the placenta, and testicles are specific for mice and rats, and are not found in humans. Controversial data were obtained regarding factor Tex19.1. According to some reports, Tex19.1 affects the regulation of MMERVK10C repeats and does not affect L1 expression in male germ cells and placenta [228-230]. In contrast, in other studies, it was shown that Tex19.1 can interact with L1-ORF1 and stimulate both polyubiquitinylation and proteasome-dependent degradation of L1 using UBE2A/UBR2 in the placenta and embryonic stem cells [229,231].

\subsection{Features of L1 Regulation during Human Embryonic Development}

In a recent study, L1HS activation was shown in preimplantation embryos and placenta in humans with an expression peak on day E8 of the embryonic development [232]. Previous study showed there was no short-term decrease in methylation and L1HS activation in the early stages, but there was a decrease in methylation and an increase in L1 expression in the placenta in the third trimester compared to the first trimester, probably associated with a decrease in DNMT3B expression [233]. Features of L1 activity in various tissues during human embryonic development remain poorly understood (Figure 3). The largest number of somatic mutations were detected in the human brain compared to other tissues such as the heart and liver $[113,139,234-236]$. DNA methylation in humans, as well as in mammals, is carried out by three main methyltransferases: DNMT1, DNMT3A, and 
DNMT3B $[237,238]$. DNMT3A and DNMT3B are mainly responsible for de novo methylation in the region of pericentromeric heterochromatin [141], while DNMT1 maintains an inherited DNA methylation profile in dividing cells [239]. Unlike the DNMT3A and $D N M T 3 B$ enzymes, whose knockout does not impair the viability of human embryonic culture cells, DNMT1 knockout in a culture of human embryonic cells leads to their immediate death [114]. Despite this, in human neural progenitor cells (hNPCs), DNMT1 knockout did not lead to their death but rather increased the expression of young L1HS and the closest L1 families (L1PA2 and L1PA3). In contrast older L1 families and other repeats of HERV, SINE, and SVA, despite the absence of methylation, remained silent [240]. In neuronal progenitor cells of mice and humans, the transcription factor involved in the DNA methylation of the L1 promoter region is MePC2 (methyl-CpG-binding protein 2) [241]. MePC2 selectively represses L1 elements specifically but not other retrotransposons [242]. On the culture of neuronal progenitor cells of mice and humans, it was shown that mutations in this gene lead to an increase in L1 activity [113]. The L1 5'UTR region contains several binding sites for transcription factors, one of which is zinc finger protein Yin Yang 1 (YY1) [243]. A high expression level of the transcription factor $Y Y 1$ is observed in the brain during embryonic development [244]. The YY1 binding site is the most evolutionarily conserved in many L1s and has a dual role in regulation as an activator and repressor [237-239]. According to one of the earlier studies, YY1 has only minor effects on promoter activity but is required for proper initiation of L1 transcription [27]. At the same time, a recent study showed that in human embryonic stem cells (hESCs), neural progenitor cells, hippocampal neurons, brain and liver tissues, and younger L1 families (L1HS and L1PA2) are repressed using the YY1 transcription factor, which facilitates methylation of the L1 promoter [110]. A slight truncation of the L1 $5^{\prime} \mathrm{UTR}$ region containing the YY1 site avoids repression [110]. The repression of older L1 families that rose to 26.8-7.6 Ma ago (L1PA3-L1PA6) in human embryonic cells is carried out through histone modification, which is regulated by factor KAP1 (TRIM28) $[109,110]$. KAP1 (KRAB-associated protein 1, tripartite motif protein 28 (TRIM28)) are cofactors of KRAB-ZFPs (DNA-binding Krüppelassociated box domain-containing zinc finger proteins) $[149,245,246]$, the activation of which leads to the histone $\mathrm{H} 3$ lysine 9 trimethylation (H3K9me3) using methyl transferase SETDB1 (ESET) and the formation of heterochromatin using the heterochromatin protein 1 (HP1) [247-249]. Recently, it was shown that the HUSH complex is also involved in the regulation of SETDB1 [111,250]. The HUSH complex also recruits MORC2 ATPase to form heterochromatin $[111,251]$. The activity of the HUSH complex in humans contributes to the repression of old families of L1P and L1M retrotransposons in the introns of active genes [111]. DNA methylation and histone methylation are interrelated, thus, recently it was found that DNMT1 recognizes heterochromatin markers H3K9me3 and H4K20me3, which profoundly impacts DNA methylation [252,253]. A low level of expression in the mammalian embryonic and adult brains is observed for PIWI family proteins. Whether the piRNA/PIWI-signaling pathway plays any role in the repression of human retrotransposons in brain is unclear [184,244,254-256]. However, in an experiment in mice, it was found that although the expression level of the a murine PIWI protein (Mili) is very weak, its knockout leads to hypomethylation of the regions of L1 promoters in the hippocampus and prefrontal cortex, and affects locomotor and cognitive function, causing hyperactivity and reducing anxiety [255].

\subsection{L1 Regulation in Somatic Cells}

In most somatic cells in the organism, L1 is repressed and its activation is associated with various pathologies, such as cancer and some autoimmune and neuropsychiatric diseases [257-261]. An exception is brain tissue, where L1 activity seems to be a common in neurons and glial cells [262,263]. The mechanisms of L1 regulation in somatic cells are mostly studied in cultured cells derived from human and mouse cancerous, stem, and embryonic tissues. Some molecular mechanisms such as DNA methylation and decreased chromatin availability for controlling the distribution of L1 are formed during 
embryonic development and persist during life [264-267]. For many factors it is currently not known whether they participate in the further repression of L1 in the process of postnatal development due to their expression in the tissues of the adult organism or whether they are limited to the stages of embryonic development.

Next, methods for the regulation of L1 elements specific to various somatic tissues will be considered (Figures 3 and 5).

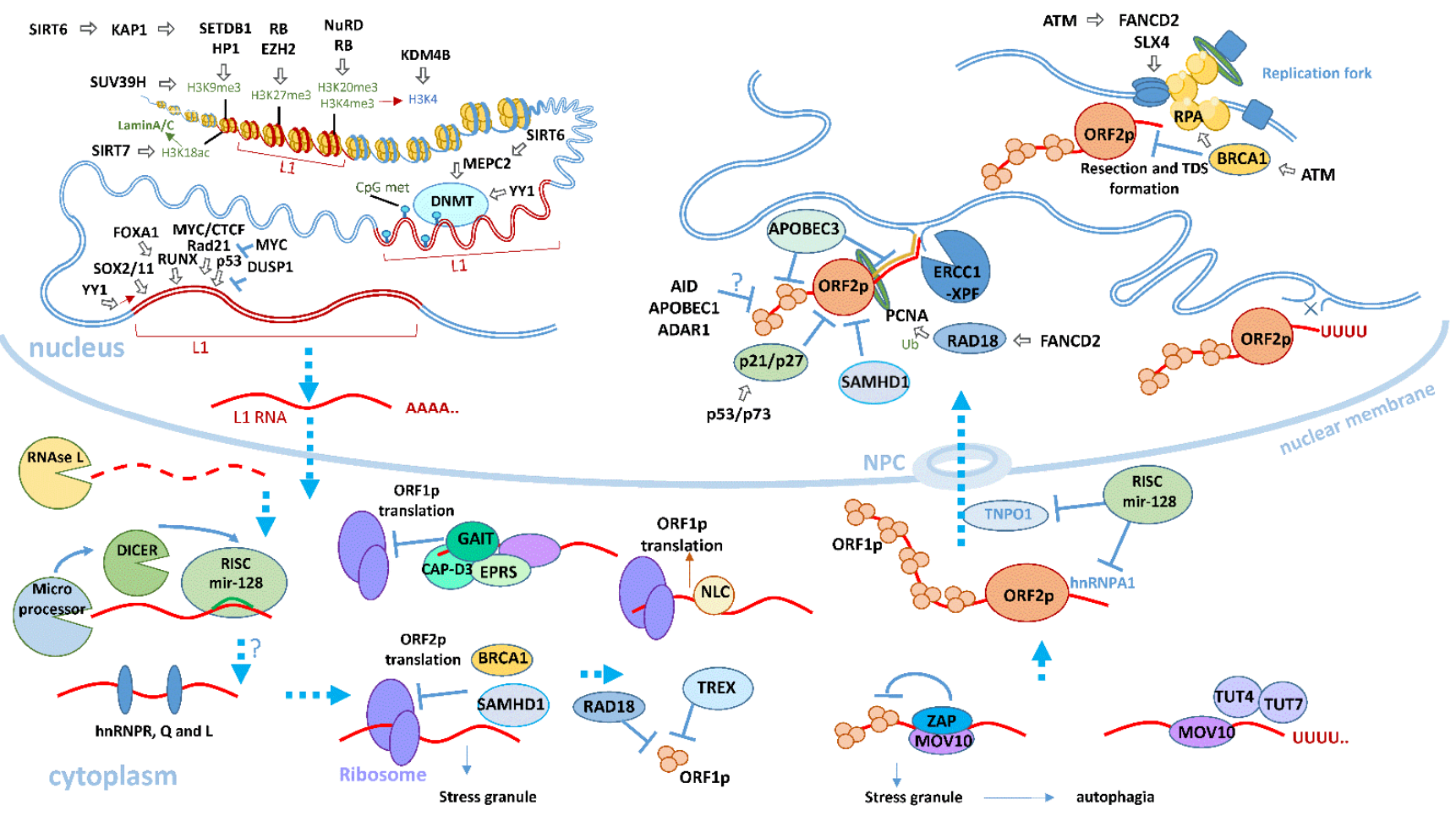

Figure 5. Scheme of L1 regulation at various stages of the process of retrotransposition in somatic cells. The upper left part of the figure shows the regulation of L1 expression: inhibition by decreasing chromatin availability due to DNA and histone methylation, and increased expression in the region of open chromatin and with the participation of transcription factors. In the cytoplasm, L1 is inhibited by microRNA pathways and interferon-activated factors involved in both the cleavage of the L1 transcript and in preventing the formation of L1 RNP (shown at the bottom of the figure). The binding of factors to the L1 internal ribosome entry site can both inhibit and promote the translation of proteins. Integration into the genome is impeded by both antiviral factors and factors of DNA repair and the cell cycle (shown in the upper right part of the figure). DNA repair factors are also required for the integration of a new copy into the genome.

\subsubsection{L1 Regulation by Decreasing Chromatin Availability in Somatic Cells}

In most normal somatic tissues, L1 is repressed by DNA methylation and specific histone modifications (Figure 5). Currently, several factors are known that regulate the availability of chromatin in L1 regions in somatic tissues, including MEPC2, KAP2, sirtuins, and the NuRD complex $[109,110,113,267-269]$. Changes in the L1 methylation profile are often found in various forms of cancer [257,258,270,271]. Alcohol, smoking, and narcotic substances can cause a change in the methylation profile and L1 activation [265,272-277]. The methylation profile can be changed in somatic tissues under influence of various exogenous and endogenous factors, including age-related changes or some diseases [278-281]. There is an opinion that prenatal immune activation may affect the methylation profile in offspring in the adult brain [282-285]. Recently, data were obtained suggesting that, in adult mice, prenatal immune activation results in a change in the methylation profile of $\mathrm{L} 1$ and $M E P C 2$ in the brain in the prefrontal cortex and striatum [264].

Sirtuin genes are associated with life span and longevity, and are involved in many cellular processes, such as DNA repair, telomere length regulation, anti-inflammatory 
processes, protection against malignanttumors, cell proliferation, ribosomal and protein synthesis, metabolism, and many other processes [286-290]. One of the functions of the SIRT6 gene is the suppression of L1 elements, carried out in two ways [267]. In the first case, mono-ADP (mono-ADP) ribosylation of factor KAP1 occurs, which in turn stimulates the formation of heterochromatin. Another less studied pathway is possible through interaction with the transcription factor $M E P C 2$, which is involved in the methylation of the L1 promoter region. Knockout of the SIRT6 gene in mice causes a several-fold increase in L1 expression and significantly increases the number of retrotranspositions [267]. Recently, another sirtuin gene, SIRT7, has been identified, which also inhibits the activity of L1, mainly concerning young families capable of retrotransposition in both mouse and human cells [268]. Interestingly, the L1 suppression mechanism identified by the authors of the article is fundamentally different. SIRT7 promotes the deacetylation of H3K18 histones and the formation of heterochromatin, which results in the association of L1 elements with the nuclear lamin A/C and their repression [268]. Repression of L1 using SIRT6 and SIRT7 can occur in various somatic tissues of the brain, liver, heart, and many others, including those involved in embryonic development [244,267]. A decrease in SIRT6 expression is shown in mice with age, especially in the brain, which leads to an increase in L1 expression and the development of the inflammatory process $[267,291,292]$. SIRT7 can also negatively affect the activity of Suv39h1 methyltransferase through inhibition of SIRT1 [293], for which a decrease in histone H3K9 methylation in the L1 region was noted with age in muscles in mice [294].

In addition to sirtuins, the nucleosomal and remodeling deacetylase multiprotein complex (NuRD) can lead to the formation of heterochromatin in both somatic and embryonic tissues [269]. This complex includes dermatomyositis-specific autoantigen Mi2 (Mi2- $\beta$ ), retinoblastoma-binding protein 46 and 48 (RbAp46 and RbAp48), methyl-CpG-binding domain protein 2 and 3 (MBD2 and MBD3), and metastasis-associated 1 family member 2 and 3 (MTA2 and MTA3), whose knockout is critical for L1 repression [269,295-297]. The NuRD complex binds to the 5'UTR promoter of the L1 elements due to the DNA and ATPase-binding domains of the Mi2- $\beta$ subunit [298]. Moreover, retinoblastoma ( $\mathrm{Rb})$ proteins play an important role in the stabilization of the NuRD complex, the knockout of which leads to the delocalization of Mi2- $\beta$ in the cytoplasm, disrupting the complex structure and leading to L1 activation $[269,299]$. Retinoblastoma $(\mathrm{Rb})$ proteins can also form a complex with EZH2, which promotes the formation of H3K27me3 heterochromatin markers in the regions of various repeats: simple, satellite, transposons, and retrotransposons, including L1 [300].

\subsubsection{Post-Transcriptional L1 Regulation in Somatic Cells}

There is a large number of cellular factors involved in the restriction and degradation of L1 transcripts at the post-transcriptional level (Figures 3 and 5). Some of these factors act specifically with respect to L1, for example, by RNA interference mechnisms, while the effect of others is related to interferon-induced protection in response to various foreign nucleic acids and dispersed repeats.

\subsubsection{RNA Interference and miRNA Factors}

RNA interference is an effective way of specific inhibition of L1 elements in somatic cells. Inhibition of L1 in somatic cells is carried out using miR-128, which together with the Ago protein form the RISC complex [301-303].

L1 repression by miR-128 can be processed through different mechanisms: by direct binding to the L1 mRNA transcript in the ORF2 region, leading to subsequent degradation of the transcript [301]; and by inhibiting cellular factors that facilitate the L1 RNP transportation from the cytoplasm to the nucleus, namely transportin-1 (TNPO1) [302] and hnRNPA1 [303]. TNPO1 is a cellular factor involved in the transport of proteins from the cytoplasm to the nucleus $[304,305]$. The cellular factor hnRNPA1 stabilizes the polyA end of various transcripts, including L1 RNA, and is involved in the intracellular trans- 
portation as well as accompanies mature transcripts through the nuclear pore complex (NPC) $[303,306]$. Other heterogeneous nuclear ribonucleoproteins (hnRNPs), namely R, $\mathrm{Q}$, and L, also participate in the L1 inhibition by another mechanism, the details of which remain unexplored. However, it is known that their effect occurs through binding to the internal ribosomal entry sites (IRESs) in the region of $5^{\prime}$ UTR $[307,308]$. Several protein complexes (Microprocessor and Dicer) are involved in the process of miRNA maturation. A microprocessor consists of a DROSHA, an RNAse III enzyme and two DGCR8 molecules, and a double-stranded RNA binding protein [309-311]. It binds to the pri-miRNA hairpin structure and cleaves it, which then undergoes further cleavage with DICER, and, together with Ago proteins, forms the RISC complex [312]. There is an alternative mechanism in which the Microprocessor is also able to directly inhibit L1 by recognizing the pri-miRNAlike harpin structure in the region of the $5^{\prime}$ UTR L1 transcript and cleaving it, which prevents further maturation of the L1 copy [313].

\subsubsection{Antiviral Factors}

Intracellular antiviral defense mechanisms of the cells also extend to dispersed repeats (Figures 3 and 5). In response to INF-induced stimuli, activation of intracellular factors of the innate immune response occurs. These include factors involved in the inhibition of viral nucleic acids, which are also involved in the inhibition of various retroelements, including L1 [119]. Although antiviral intracellular factors are activated in response to both viral nucleic acids and retroelements, the same factor can use different inhibition mechanisms against viruses and retrotransposons [314-316]. The effectiveness of the inhibition of L1 and the viral agents is also not the same [317]. Moreover, recent studies have shown that L1 can be activated in response to a viral infection and can stimulate the innate immune response [318-320]. L1 activity can also be suppressed by viruses. For example, it has been shown that HIV-1 suppresses L1 retrotransposition by binding to ORF2 using the Vpr protein included in HIV-1 [321] or the hepatitis C virus, which provokes the formation of ORF1 stress granules [322]. Defects in many L1 inhibitory antiviral immune response genes are associated with autoimmune diseases such as Aicardi-Goutières syndrome [323].

The following are various antiviral cell factors that inhibit L1 in somatic cells.

Interferon-Induced Factors Inhibiting the Formation of L1 RNP

In response to a viral infection, the interferon-induced ribonuclease $\mathrm{L}\left(2^{\prime}, 5^{\prime}\right.$-oligoadenylate (2-5A) synthetase (OAS) -RNase L, RNAse L) is activated, which cleaves cellular and viral RNA [117]. The enzymatic activity of RNAse L has also been shown with regard to L1 mRNA and other IAP retrotransposons, which leads to a significant decrease in the ORF1 and ORF2 L1 proteins [324]. The cleavage of RNA molecules into small pieces using RNAse L leads to the activation of RIG-I (DExD/H-box helicase 58, DDX58) and MDA5 (interferon induced with helicase $C$ domain 1, IFIH1) sensors, which in turn activate MAVS and stimulates both the production of interferon and the immune response [325-327]. Recent studies have shown that expression of L1 mRNA triggers an immune response through RIG-I and MDA5 sensors, and increases the level of interferon $\beta$ INFB [318].

Many studies have confirmed that the strong L1 inhibitor is the MOV10 helicase RNA [215,328-331]. The mechanism of the MOV10 action remains to be fully understood but it is known that MOV10 forms a complex with other antiviral proteins, which, when interacting with L1 transcripts, forms stress granules that undergo further degradation $[215,330]$. Mass spectrometry of stress granules revealed other key proteins complexed with MOV10 helicase. One of these proteins is zinc finger CCCH-type containing antiviral protein 1 (ZAP or ZC3HAV1) [120,332]. ZAP forms a complex with MOV10 that binds to L1 RNA and blocks ORF1, which then leads to the formation of stress granules with subsequent degradation. Additionally, in a recent article, the interaction of MOV10 with ribonuclease H2 (RNASEH2) has been shown. This interaction can prevent the formation of RNA-DNA L1 heteroduplexes, which are necessary for retrotransposition [329]. Interestingly, another study showed the important role of RNase H2 in L1 retrotransposition. 
It is assumed that this enzyme degrades L1 RNA after reverse transcription and thus contributes to the completion of L1 integration in the genome [333]. Studies have shown that in various human cells and testes of mice, a new L1 RNA copy undergoes $3^{\prime} \mathrm{UTR}$ urinylidylation as a result of the activity of TUT4 and TUT7 uridine transferases; undergoes complexation with the MOV10 RNA helicase; and subsequently degrades [334]. The MOV10-ZAP complex inhibiting L1 contains another component of glutamyl-prolyl tRNA synthetase (glutamyl-prolyl tRNA synthetase, EPRS) [43,120]. The EPRS synthetase is able to bind RNA and is a component of various complexes, one of which is the $\gamma$-interferonactivated inhibitor of the translation complex (GAIT) [335]. The GAIT complex binds to mRNA and inhibits its translation by repressing the translation initiation factor eIF4G by attaching the L13a subunit of this complex. The interaction of eIF4G and L13a blocks the $43 S$ preinitiation complex and inhibits translation initiation [336]. It was revealed that EPRS also interacts with the CAP-D3 subunit of the Condensin II complex. It is assumed that such interaction is necessary for the formation of the active GAIT complex with the L1 transcript and for the further inhibition of L1 ORF1 translation [337]. Despite the fact that activation of the GAIT complex occurs in response to interferon $\gamma$ [338], inhibition of L1 by the Condensin II-GAIT complex occurs independently of interferon $\gamma$ [337].

Three-prime repair exonuclease I (TREX1) is an antiviral enzyme activated in response to interferon type 1 and cleaves nucleic acids [339]. It is also involved in the inhibition of L1 and other retroelements but, similar to the MOV10-ZAP complex, it uses an exonuclease-independent mechanism. There are no exact data on whether TREX1 is part of the MOV10-ZAP complex, but in the same way as the enzymes described above, the L1 inhibition mechanism consists of binding the L1 ORF1 protein and changing its intracellular localization as well as its further removal [340]. TREX1 is located in the endoplasmic reticulum (ER) [341,342], where ER-dependent protein degradation occurs [343].

The SAM domain and HD domain-containing protein 1 (SAMHD1) are some of the most well-known protective factors of innate immunity, inhibiting the replication of viruses and participating in the repression of both L1 and other retroelements [344]. The mechanism of inhibition of L1 differs from the antiviral inhibition and is observed in dividing cells [316]. Unlike the MOV-ZAP and Condensin II-GAIT complexes that block ORF1, SAMHD1 interacts with ORF2; the details of this repression are not completely clear and various authors have presented several ways of inhibiting L1 [121,316,345]. In a cell, SAMHD1 is located mainly in the nucleus [346], where SAMHD1 binds to ORF2, inhibits the reverse transcription of L1, and reduces the expression of ORF2 proteins (ORF2p) [316]. In another study, despite the nuclear arrangement of the enzyme, a SAMHD1 mechanism of L1 inhibition in the cytoplasm was revealed, which, through phosphorylation of the translation initiation factor eIF $2 \alpha$ and through a decrease in the interaction of translation initiation factor eIF4A/eIF4G, leads to the activation of stress marker factors G3BP1 and TIA1, as well as to the formation of large stress granule of L1 [347]. In another study, it was found that SAMHD1 binds to ORF2p at the stage of the L1 RNP functional complex; moreover, the inhibitory activity of SAMHD1 against L1 is regulated by phosphorylation of threonine 592, the dephosphorylation of which correlates with the repression of L1 [121]. In addition to this site, another polymorphic site S33 phosphorylation was identified, which contributes to the inhibition of L1 [348]. As shown in a recent work, SAMHD1 is a nucleocytoplasmic shuttling protein and thus is possibly involved in the inhibition of L1 in the cytoplasm and nucleus, and the presence of SAMHD1 in the cytoplasm contributes to a decrease in ORF2p [349]. RNA granules, in which L1 RNA transcripts are localized, undergo autophagy, facilitated by the NDP52 (CALCOCO2) and p62 (SQSTM1) receptors [122]. Knockout of these receptors, as well as autophagy factors of BECN1, leads to an increase in L1 [122]. One of the new studied alternative ways of inhibiting L1 is the activation of TRIM25alpha, a known antiviral factor [350]. It is assumed that the TRIM25alfa mechanism of L1 inhibition is similar to HIV-1 inhibition; thus, TRIM25a using its CC region, B-box, and SPRY domains forms multimeric lattices that promote the binding to L1 RNP in the cytoplasm, blocking further stages of L1 retrotransposition [351,352]. In addition, 
TRIM25a acts as a cytoplasmic L1 receptor and initiates an innate immune response through the activation of the AP- 1 and NF-kB factors, leading to the downregulation of the L1 promoter [352].

\section{Deaminases}

The $A P O B E C 3$ protein family is one of the first discovered cellular defense molecules against the uncontrolled spread of L1 [119,125,353,354]. In various human cell cultures, data were obtained showing that most of the proteins of the APOBEC3 family (hA3A, hA3B, hA3C, hA3F, and hA3DE) have inhibitory activity against L1 [355-359]. Weak inhibitory activity or its absence was observed for hA3D [357], and conflicting results were obtained for two other hA3G and hA3H enzymes [356-358]. Inhibition of L1 by APOBEC3 occurs at the post-transcriptional level by a deamination-dependent or independent mechanism. Various studies suggest that representatives of the APOBEC 3 family of proteins have different mechanisms of inhibition of L1 $[119,358,360]$. The most active enzyme with respect to L1 hA3A has deaminase activity and converts cytosine to uracil in the first strand of the L1 cDNA transcript. As a result of such modification, the L1 copy undergoes further degradation [360,361]. A different mechanism has been identified for hA3C and hA3DE: acting by a deamination-independent mechanism, the enzyme blocks the L1 reverse transcription reaction by interacting with the L1 complex of RNP and ORF1 in the cell cytoplasm [362,363]. hA3B is less able to inhibit the reverse transcriptase activity of L1. It has an exclusively nuclear arrangement and appears to use an alternative mechanism [363-365]. In addition to the $A P O B E C 3$ family, which is present only in humans, other types of proteins that are evolutionarily more conservative with deaminase activity are also active against L1: AID [366], APOBEC1 [314], and ADAR1 and ADAR2 [367,368]. APOBEC1 deaminase, similar to other enzymes, is active against viruses and retrotransposons. Interestingly, $A P O B E C 1$ acts by a deamination-independent mechanism with respect to L1, while, with respect to other repeats and viruses, it uses a deamination-dependent mechanism [314]. AID [366] and $A D A R s[367,368]$ also act using the deamination-independent mechanism. Expression of $A P O B E C 3, A I D$, and $A P O B E C 1$ deaminases is observed in various somatic tissues and a high level of expression is observed in the connective tissues (blood and adipose tissue); in the organs of the immune, digestive, respiratory, and reproductive systems; and in embryonic stem cells $(A 3 B, A 3 C, A 3 D, A 3 F$, and $A 3 G)[244,369]$. All deaminases have a low level of expression in the brain, with the exception of ADARs which have a high level of expression in various parts of the brain [244].

\subsubsection{L1 Integration into the Genome and DNA Repair Mechanism}

At the last stage of retrotransposition, which is the integration into the genome, the inhibitors are proteins involved in the repair of single and double-stranded DNA breaks (Figures 3 and 5). It was initially revealed that double-stranded DNA breaks and defects in repair factors of non-homologous end-joining (NHEJ) protein kinase DNA-PKCs (PRKDC, XRCC7) and XRCC4 can contribute to L1 retrotransposition [49,50]. At the same time, some factors, such as DCLRE1C (artemis), LIG4, and XRCC6 (Ku70/Ku80), participate in retrotransposition and contribute to the truncation of L1 c $5^{\prime} \mathrm{UTR}$, thus limiting the distribution of full-length active copies [46]. An effect on L1 activity was also detected for factors involved in the repair of single-stranded breaks using the nucleotide excision repair (NER) mechanism [123,124]. The dual role of the ERCC1/XPF complex in the regulation of L1 retrotransposition was previously suggested in one study [123]. The authors showed that the XPF factor inhibits L1 integration, while a deficiency of the ERCC1 factor leads to a decrease in L1 retrotranspositions [123]. Later, the details of the L1 regulation using NER factors were specified and a possible mechanism for inhibiting L1 retrotransposition was suggested [124]. Then, the XPA factor joins the ERCC1-XPF complex, which contributes to its enzymatic activity at the L1 integration site [370]. Interestingly, the lack of NER factors leads to an increase in the length of the targeted site duplication [124]. Defects in 
NER genes are associated with diseases of xeroderma pigmentosum (XP) and Cockayne syndrome [371,372].

A large contribution to the inhibition of L1 is made by factors involved in postreplicative DNA repair. One of the first discovered was the ATM gene, mutations in which lead to ataxia-telangiectasia [373]. In response to damage, ATM triggers the factors CHK2, p53, BRCA1, and the MRN complex (MRE11, Rad50, and NBS1), involved in the repair of post-replicative DNA and cell cycle regulation factors [373-375]. A lack of the ATM enzyme leads to an increase in L1 activity [45]. In response to cellular stress, repair factors are activated, combining various DNA repair pathways including $N E R$, translesion synthesis, and homologous recombination [375]. An increase in L1 activity was detected in cases of deficiency of the DNA repair factor FANCD2 and SLX4, defects of which are associated with Fanconi Anemia (FA) disease [376]. The SLX4 complex blocks the distribution of L1 with the complex formed during the retrotransposition in the replication fork [377]. The factor FANCD2 is an activator and platform for the formation of the repair complex SLX4 for its aggregation with other factors including ERCC4, MUS81, and FAN1 [375]. Moreover, FANCD2 activates the translesion synthesis factor, RAD18 ubiquitin ligase, which is also involved in the inhibition of L1 activity. RAD18 causes monoubiquitinylation of the sliding clamp protein PCNA, which interacts with L1 ORF2 during retrotransposition [43,378]. Thus, RAD18 may possibly limit the insertion of L1 into the genome [377]. At the same time, the interaction of the Rad-6 domain (E2 ubiquitin-conjugated enzyme-binding domain) of the Rad18 factor with L1 ORF1 proteins was found, leading to the formation of $P$ bodies and stress granules [377]. In addition, the Rad18 protein also suppresses Alu retrotransposons and HIV-1 DNA elements [377,379,380]. In a recent study, the role of post-replicative repair factors, homologous recombination, and BRCA1 ubiquitin ligase in suppressing L1 retrotranspositions were analyzed [126]. The authors proposed the following mechanism: BRCA1 prevents the insertion of L1 into the replication fork by initiating double-stranded cleavage, resection, and urgent protective coating of DNA ends with RPA proteins. As a result, this mechanism leads to the formation of a targeted site duplication. In addition, in the cytoplasm, BRCA1 can inhibit the translation of ORF2 and the formation of functional L1 RNP [126].

\subsubsection{Regulation of $\mathrm{L} 1$ by Cell Cycle Factors}

Cell cycle factors are involved in the regulation of L1 activity (Figures 3 and 5). However, their effect on L1 activity is ambiguous. The $5^{\prime} \mathrm{UTR}$ promoter of the L1 active and evolutionarily close families not older than 20 mya (L1Hs, L1PA2, and L1PA3) has the region of the transcription factor p53 binding site. In vitro experiments have shown that interaction of p53 with the L1 promoter increases the expression of these repeats [381]. In addition, experiments on model organisms of the fruit fly and zebrafish revealed a mechanism of L1 suppression induced by p53 via activation of the piRNA-signaling pathway in germ cells [382]. A correlation was also found between p53 and the repressing histone marker H3K9me3 in the L1 5'UTR in zebrafish embryos [382]. In addition to this, it has been shown that p53 inhibits L1 in cancer-derived and normal lung tissue from human cell cultures by binding to the $5^{\prime}$ UTR and stimulating local deposition of repressive histone marks [383]. Additionally, inhibition of L1 has been shown to occur by other transcriptional factors regulating the cell cycle, namely p21 and p27 [321]. These factors do not affect the transcription of L1 but bind to the ORF2 protein, thus preventing the integration of L1 [321]. In turn, activation of p21 and p27 can occur using p53 and p73, for which L1 inhibition is also shown [321]. MYC proto-oncogene is involved in many cell processes and in the regulation of the cell cycle, the defects of which are often found in cancer [384]. MYC binding to the L1 5'UTR represses transcriptional activity. However, this has only been shown for some types of cancer cells [385]. Activity of Dual Specificity Phosphatase 1 (DUSP1) downregulate L1 in cancers cells [386]. DUSP1 is also known as mitogen-activated protein kinase (MAPK) phosphatase-1 (MKP-1), which is involved in the negative regulation of cellular proliferation and the suppression of inflammation [386]. 


\subsubsection{Positive Regulation of L1}

In the region of the $5^{\prime}$ UTR $(+83$ to +101$)$ L1HS, there is a binding site for the transcription factor RUNX3 (runt-domain transcription factor). The binding of this factor increases the expression and retrotransposition of L1HS elements. In addition, another RUNX3 binding site is located on the antisense chain of the L1HS promoter $(+526$ to +508$)$, thus expression also occurs in the antisense orientation of nearby sequences [387]. The transcription factor RUNX3 is expressed in many human tissues and the highest level of expression is found in the blood, skin, lungs, and digestive organs, but expression of the transcription factor is practically absent in the brain $[244,387]$. The L1 promoter region also contains two SRY-binding sites for the SOX transcription factor family [388], expressed in embryonic tissues, testes, and in various tissues in the adult body with the highest expression level in the brain, especially for the SOX2 factor [244]. SOX11 regulates L1 during the differentiation of neuronal tissues $[388,389]$. SOX2 enhances L1 expression in hippocampal neuronal stem cells in the adult brain $[113,390]$. Histone demethylase KDM4B is also a positive regulatory factor for L1, which promotes the demethylation of $\mathrm{H} 3 \mathrm{~K} 9 \mathrm{me} 3$ histones [391]. Its increased activity is observed for various types of cancers [392-394]. The transcription factor FOXA1, the activity of which is associated with embryonic and postembryonic development, as well as with various cancers [395], can act as an activator of L1 expression [291]. In a recent study, its positive regulation of L1 was found during cellular ageing and senescence-associated secretory phenotypes (SASP), characterized by increased expression of immune factors [291,396]. In addition, in this phenotype, there is a decrease in the activity of the TREX1 and RB1 involved in the repression of L1, despite an increase in the level of interferon I [291]. The authors suggest that L1 activation and the inflammation caused by this activation are the hallmarks of ageing, and therefore a change in $\mathrm{L} 1$ regulation is a potential target for the treatment of age-related disorders. CTCF is involved in L1 activation, colocalizing with MYC in the L1 5'UTR promoter and 3'UTR region, and acts as an $M Y C$ repressor [385]. Moreover, CTCF also forms a complex with Cohesin subunit Rad21, for which there is also the evidence of positive regulation of L1 [397]. In the region of the L1 $5^{\prime} \mathrm{UTR}$ transcript, there are binding sites of the internal ribosome entry site (IRESs), through which it binds to heterogeneous nuclear ribonucleoproteins and to the NCL nuclein, the latter being a positive factor for L1 activity [308]. Its interaction with L1 increases the level of expression of ORF1 (Figures 3 and 5) [146,308,398]. It is also worth noting that in a recent study of cancer research, the ability to bind L1 was found for many transcription factors, among which new and previously described ones were found, such as ESR1, MYC, CCTCF, FOXA1, NR2F2 and E2F1, etc. Moreover, the authors showed the formation of new binding sites in the case of L1 truncation [399].

\section{Factors Affecting Changes in L1 Regulation in Neuropsychiatric Diseases}

Normally, L1 can be active in the brain $[113,138,139,234-236]$. In some neuropsychological pathologies, changes in L1 activity were detected. The most pronounced increase in L1 activity was found in Rett syndrome [241] and autism [400], as well as in ataxia telangiectasia [45]. The genetic causes that lead to an increase in L1 activity have been mostly studied with Rett syndrome and ataxia telangiectasia, and are associated with damage in the MEPC2 and ATM genes [45,113]. The L1 control mechanism of these genes is described above. Some trends are observed in schizophrenia [401,402] and major depressive disorder [403]. However, the causes and factors that change the activity of L1 elements remain unknown for most diseases. Recently, some studies demonstrated the connection of genetic factors associated with neurodegenerative pathologies and L1 activity. One of these factors is the TAR DNA-binding protein (TDP-43), which is able to bind DNA and RNA, and is involved in the regulation of many processes [404]. TDP-43 is associated with neuropsychiatric pathologies such as amyotrophic lateral sclerosis (ALS) and frontotemporal degeneration (FTD) [405]. The protein cleavage, hyperphosphorylation, and aggregation in the form of ubiquitinated granules in the cytoplasm occur in the pathologies. Similar the TDP- 43 "proteinopathy" occurs in other neurodegenerative diseases such 
as Alzheimer's disease [406], Parkinson's disease [407], and Huntington's disease [408], and also with hereditary inclusion body myopathy (HIBM) [409]. Controversial results have been obtained regarding the effect of TDP-43 on L1 activity. TDP-43 is involved in many processes that can affect L1 activity, such as in autophagy, which contributes to the destruction of L1 stress granules [410], and in double-stranded DNA repair, wherein it binds to the damaged site and provides further formation of the XRCC4-DNA ligase IV complex, the activity of which can contribute to retrotransposition [49,50,411]. Additionally, in one of the latest studies, data were obtained regarding the inhibitory effect of TDP-43 on L1 activity and its absence was found to increase the level of L1 retrotranspositions by chromatin decompactivation [412]. Despite this, other studies obtained different results, showing that TDP-43 regulates the transcription of many genes and retrotransposons of Alu elements, and does not affect the activity of L1 elements [413,414]. In addition, an increase in HERV-K retroviral repeats was noted, while no changes in L1 activity were detected in lateral amyotrophic sclerosis $[415,416]$. The change in the expression of retrotransposons is also associated with the Tau protein encoded by the MAPT (microtubule-associated protein tau) gene $[417,418]$. Tau pathology is observed in various neurodegenerative disorders including Alzheimer's disease $[419,420]$. The Tau protein hyperphosphorylates and forms hyperphosphorylated insoluble aggregates called neurofibrillary tangles [421-423]. One study showed activation of various retrotransposons, including L1 that lost the ability to retrotranspose due to accumulated mutations in the transcriptional reading frame [418]. We revaled no significant changes in the copy number of L1 in Alzheimer's disease [136]. Another study showed an increase in the expression of endogenous retroviruses, but not of active L1, as a result of chromatin decondensation and a decrease in both piRNA and piwi proteins associated with Tau pathology in Alzheimer's disease [417]. Mitochondrial dysfunction and oxidative stress are characteristic features of a number of diseases such as some forms of ataxia, neurodegenerative diseases (Parkinson's disease in particular), various forms of cancer, and other diseases [424-427]. Recent studies have shown that abnormalities and a deficiency of both the mitochondrial chain and oxidative stress cause DNA hypomethylation and increased L1 activity [428-430]. The stress sensor GABB45B gene was connected to the death of dopaminergic neurons in Parkinson's disease [431]. A recent study in mice shows that overexpression of Gadd45b leads to disorganized heterochromatin, increased DNA damage, vulnerability to oxidative stress, and further stable changes in DNA methylation, particularly in introns of neuronal genes harboring L1 [432].

\section{Conclusions}

The process of regulating the activity of L1 retrotransposons is a complex multifactor orchestra, the coordinated activity of which is extremely important for the healthy development of the organism. Factors that control L1 activity are involved in many biological processes, including cell division, immune response, ageing, and neuronal functions. Many cellular factors are aimed at limiting the activity and repropositions of L1 in genome. A much smaller number of factors positively regulate L1. L1 activity is necessary in some stages of development. The functional role of L1 elemets is intriguing and not yet fully elucidated. Recent studies showed the L1 contribution to the early embryonic development, the inflammation, the cell cycle and cellular senescence. Recently, a major breakthrough has been made in understanding the molecular genetic mechanisms of the retrotransposition and regulation of L1 activity. However, many factors involved in the process of the retrotransposition and regulation of L1 in pathologies are not yet known.

Moreover, this research area also has prospects for understanding the pathogenesis and development of therapies for autoimmune and viral diseases, neuropsychiatric disorders, and oncological diseases. The strict regulation of L1 elements during germline and embryonic development, as well as the various defects in L1 regulatory factors have been extensively studied on mouse models. Thus, this provides a foundation for research in human reproduction and embryology. The investigation of genetic factors that regulate L1 activity and their defects is also of great importance in the research of rare and complex 
diseases and, potentially, modulation of certain disease conditions vis regulation of the retrotransposons.

Author Contributions: Conceptualization, M.S.P. and E.I.R.; writing—original draft preparation, M.S.P.; writing-review and editing, T.V.A. and E.I.R.; visualization, M.S.P.; supervision, E.I.R.; project administration, M.S.P.; funding acquisition, M.S.P. and E.I.R. All authors have read and agreed to the published version of the manuscript.

Funding: The study was partially supported by the Basic Research (RFBR) Research Project, number 18-315-00440 (regarding the sections on L1 structure and both retrotransposition and regulation in embryonic, germline, and somatic cells). M.P. was supported by the Russian Science Foundation (RSF), project number 19-75-30039 (regarding the section on L1 regulation in neuropsychiatric diseases).

Institutional Review Board Statement: Not applicable.

Informed Consent Statement: Not applicable.

Data Availability Statement: Not applicable.

Conflicts of Interest: The authors declare no conflict of interest.

\section{References}

1. Lander, E.S.; Linton, L.M.; Birren, B.; Nusbaum, C.; Zody, M.C.; Baldwin, J.; Devon, K.; Dewar, K.; Doyle, M.; FitzHugh, W.; et al. Initial Sequencing and Analysis of the Human Genome. Nature 2001, 409, 860-921. [CrossRef]

2. Mills, R.E.; Bennett, E.A.; Iskow, R.C.; Devine, S.E. Which Transposable Elements Are Active in the Human Genome? Trends Genet. 2007, 23, 183-191. [CrossRef] [PubMed]

3. Sassaman, D.M.; Dombroski, B.A.; Moran, J.V.; Kimberland, M.L.; Naas, T.P.; DeBerardinis, R.J.; Gabriel, A.; Swergold, G.D.; Kazazian, H.H. Many Human L1 Elements Are Capable of Retrotransposition. Nat. Genet. 1997, 16, 37-43. [CrossRef] [PubMed]

4. Brouha, B.; Schustak, J.; Badge, R.M.; Lutz-Prigge, S.; Farley, A.H.; Moran, J.V.; Kazazian, H.H. Hot L1s Account for the Bulk of Retrotransposition in the Human Population. Proc. Natl. Acad. Sci. USA 2003, 100, 5280-5285. [CrossRef]

5. Penzkofer, T.; Jäger, M.; Figlerowicz, M.; Badge, R.; Mundlos, S.; Robinson, P.N.; Zemojtel, T. L1Base 2: More RetrotranspositionActive LINE-1s, More Mammalian Genomes. Nucleic Acids Res. 2017, 45, D68-D73. [CrossRef]

6. Dewannieux, M.; Esnault, C.; Heidmann, T. LINE-Mediated Retrotransposition of Marked Alu Sequences. Nat. Genet. 2003, 35, 41-48. [CrossRef] [PubMed]

7. Ostertag, E.M.; Goodier, J.L.; Zhang, Y.; Kazazian, H.H. SVA Elements Are Nonautonomous Retrotransposons That Cause Disease in Humans. Am. J. Hum. Genet. 2003, 73, 1444-1451. [CrossRef]

8. Wang, H.; Xing, J.; Grover, D.; Hedges, D.J.; Han, K.; Walker, J.A.; Batzer, M.A. SVA Elements: A Hominid-Specific Retroposon Family. J. Mol. Biol. 2005, 354, 994-1007. [CrossRef]

9. Xing, J.; Zhang, Y.; Han, K.; Salem, A.H.; Sen, S.K.; Huff, C.D.; Zhou, Q.; Kirkness, E.F.; Levy, S.; Batzer, M.A.; et al. Mobile Elements Create Structural Variation: Analysis of a Complete Human Genome. Genome Res. 2009, 19, 1516-1526. [CrossRef]

10. Mandal, P.K.; Ewing, A.D.; Hancks, D.C.; Kazazian, H.H. Enrichment of Processed Pseudogene Transcripts in L1Ribonucleoprotein Particles. Hum. Mol. Genet. 2013, 22, 3730-3748. [CrossRef]

11. Pavlícek, A.; Paces, J.; Zíka, R.; Hejnar, J. Length Distribution of Long Interspersed Nucleotide Elements (LINEs) and Processed Pseudogenes of Human Endogenous Retroviruses: Implications for Retrotransposition and Pseudogene Detection. Gene 2002, 300, 189-194. [CrossRef]

12. Scott, A.F.; Schmeckpeper, B.J.; Abdelrazik, M.; Comey, C.T.; O'Hara, B.; Rossiter, J.P.; Cooley, T.; Heath, P.; Smith, K.D.; Margolet, L. Origin of the Human L1 Elements: Proposed Progenitor Genes Deduced from a Consensus DNA Sequence. Genomics 1987, 1, 113-125. [CrossRef]

13. Mätlik, K.; Redik, K.; Speek, M. L1 Antisense Promoter Drives Tissue-Specific Transcription of Human Genes. J. Biomed. Biotechnol. 2006, 2006, 71753. [CrossRef]

14. Swergold, G.D. Identification, Characterization, and Cell Specificity of a Human LINE-1 Promoter. Mol. Cell. Biol. 1990, 10, 6718-6729. [CrossRef]

15. Moran, J.V.; Holmes, S.E.; Naas, T.P.; DeBerardinis, R.J.; Boeke, J.D.; Kazazian, H.H. High Frequency Retrotransposition in Cultured Mammalian Cells. Cell 1996, 87, 917-927. [CrossRef]

16. Kolosha, V.O.; Martin, S.L. In Vitro Properties of the First ORF Protein from Mouse LINE-1 Support Its Role in Ribonucleoprotein Particle Formation during Retrotransposition. Proc. Natl. Acad. Sci. USA 1997, 94, 10155-10160. [CrossRef] [PubMed]

17. Naufer, M.N.; Furano, A.V.; Williams, M.C. Protein-Nucleic Acid Interactions of LINE-1 ORF1p. Semin. Cell Dev. Biol. 2019, 86, 140-149. [CrossRef] [PubMed]

18. Freeman, B.T.; Sokolowski, M.; Roy-Engel, A.M.; Smither, M.E.; Belancio, V.P. Identification of Charged Amino Acids Required for Nuclear Localization of Human L1 ORF1 Protein. Mob. DNA 2019, 10, 20. [CrossRef] [PubMed] 
19. Mathias, S.L.; Scott, A.F.; Kazazian, H.H.; Boeke, J.D.; Gabriel, A. Reverse Transcriptase Encoded by a Human Transposable Element. Science 1991, 254, 1808-1810. [CrossRef] [PubMed]

20. Feng, Q.; Moran, J.V.; Kazazian, H.H.; Boeke, J.D. Human L1 Retrotransposon Encodes a Conserved Endonuclease Required for Retrotransposition. Cell 1996, 87, 905-916. [CrossRef]

21. Macia, A.; Muñoz-Lopez, M.; Cortes, J.L.; Hastings, R.K.; Morell, S.; Lucena-Aguilar, G.; Marchal, J.A.; Badge, R.M.; Garcia-Perez, J.L. Epigenetic Control of Retrotransposon Expression in Human Embryonic Stem Cells. Mol. Cell. Biol. 2011, 31, 300-316. [CrossRef]

22. Wheelan, S.J.; Aizawa, Y.; Han, J.S.; Boeke, J.D. Gene-Breaking: A New Paradigm for Human Retrotransposon-Mediated Gene Evolution. Genome Res. 2005, 15, 1073-1078. [CrossRef] [PubMed]

23. Denli, A.M.; Narvaiza, I.; Kerman, B.E.; Pena, M.; Benner, C.; Marchetto, M.C.N.; Diedrich, J.K.; Aslanian, A.; Ma, J.; Moresco, J.J.; et al. Primate-Specific ORF0 Contributes to Retrotransposon-Mediated Diversity. Cell 2015, 163, 583-593. [CrossRef] [PubMed]

24. Adney, E.M.; Ochmann, M.T.; Sil, S.; Truong, D.M.; Mita, P.; Wang, X.; Kahler, D.J.; Fenyö, D.; Holt, L.J.; Boeke, J.D. Comprehensive Scanning Mutagenesis of Human Retrotransposon LINE-1 Identifies Motifs Essential for Function. Genetics 2019, 213, 1401-1414. [CrossRef] [PubMed]

25. Luan, D.D.; Korman, M.H.; Jakubczak, J.L.; Eickbush, T.H. Reverse Transcription of R2Bm RNA Is Primed by a Nick at the Chromosomal Target Site: A Mechanism for Non-LTR Retrotransposition. Cell 1993, 72, 595-605. [CrossRef]

26. Cost, G.J.; Feng, Q.; Jacquier, A.; Boeke, J.D. Human L1 Element Target-Primed Reverse Transcription in Vitro. EMBO J. 2002, 21, 5899-5910. [CrossRef] [PubMed]

27. Athanikar, J.N.; Badge, R.M.; Moran, J.V. A YY1-Binding Site Is Required for Accurate Human LINE-1 Transcription Initiation. Nucleic Acids Res. 2004, 32, 3846-3855. [CrossRef]

28. Dai, L.; Taylor, M.S.; O’Donnell, K.A.; Boeke, J.D. Poly(A) Binding Protein C1 Is Essential for Efficient L1 Retrotransposition and Affects L1 RNP Formation. Mol. Cell. Biol. 2012, 32, 4323-4336. [CrossRef]

29. Doucet, A.J.; Hulme, A.E.; Sahinovic, E.; Kulpa, D.A.; Moldovan, J.B.; Kopera, H.C.; Athanikar, J.N.; Hasnaoui, M.; Bucheton, A.; Moran, J.V.; et al. Characterization of LINE-1 Ribonucleoprotein Particles. PLoS Genet. 2010, 6, e1001150. [CrossRef]

30. Horn, A.V.; Celic, I.; Dong, C.; Martirosyan, I.; Han, J.S. A Conserved Role for the ESCRT Membrane Budding Complex in LINE Retrotransposition. PLoS Genet. 2017, 13, e1006837. [CrossRef]

31. Mita, P.; Wudzinska, A.; Sun, X.; Andrade, J.; Nayak, S.; Kahler, D.J.; Badri, S.; LaCava, J.; Ueberheide, B.; Yun, C.Y.; et al. LINE-1 Protein Localization and Functional Dynamics during the Cell Cycle. eLife 2018, 7, e30058. [CrossRef]

32. Macia, A.; Widmann, T.J.; Heras, S.R.; Ayllon, V.; Sanchez, L.; Benkaddour-Boumzaouad, M.; Muñoz-Lopez, M.; Rubio, A.; Amador-Cubero, S.; Blanco-Jimenez, E.; et al. Engineered LINE-1 Retrotransposition in Nondividing Human Neurons. Genome Res. 2017, 27, 335-348. [CrossRef]

33. Cost, G.J.; Boeke, J.D. Targeting of Human Retrotransposon Integration Is Directed by the Specificity of the L1 Endonuclease for Regions of Unusual DNA Structure. Biochemistry 1998, 37, 18081-18093. [CrossRef]

34. Flasch, D.A.; Macia, Á.; Sánchez, L.; Ljungman, M.; Heras, S.R.; García-Pérez, J.L.; Wilson, T.E.; Moran, J.V. Genome-Wide de Novo L1 Retrotransposition Connects Endonuclease Activity with Replication. Cell 2019, 177, 837-851.e28. [CrossRef] [PubMed]

35. Sultana, T.; van Essen, D.; Siol, O.; Bailly-Bechet, M.; Philippe, C.; Zine El Aabidine, A.; Pioger, L.; Nigumann, P.; Saccani, S.; Andrau, J.-C.; et al. The Landscape of L1 Retrotransposons in the Human Genome Is Shaped by Pre-Insertion Sequence Biases and Post-Insertion Selection. Mol. Cell 2019, 74, 555-570.e7. [CrossRef] [PubMed]

36. Doucet, A.J.; Wilusz, J.E.; Miyoshi, T.; Liu, Y.; Moran, J.V. A 3’ Poly(A) Tract Is Required for LINE-1 Retrotransposition. Mol. Cell 2015, 60, 728-741. [CrossRef] [PubMed]

37. Kulpa, D.A.; Moran, J.V. Cis-Preferential LINE-1 Reverse Transcriptase Activity in Ribonucleoprotein Particles. Nat. Struct. Mol. Biol. 2006, 13, 655-660. [CrossRef]

38. Monot, C.; Kuciak, M.; Viollet, S.; Mir, A.A.; Gabus, C.; Darlix, J.-L.; Cristofari, G. The Specificity and Flexibility of L1 Reverse Transcription Priming at Imperfect T-Tracts. PLoS Genet. 2013, 9, e1003499. [CrossRef]

39. Gibson, B.A.; Kraus, W.L. New Insights into the Molecular and Cellular Functions of Poly(ADP-Ribose) and PARPs. Nat. Rev. Mol. Cell. Biol. 2012, 13, 411-424. [CrossRef]

40. Miyoshi, T.; Makino, T.; Moran, J.V. Poly(ADP-Ribose) Polymerase 2 Recruits Replication Protein A to Sites of LINE-1 Integration to Facilitate Retrotransposition. Mol. Cell 2019, 75, 1286-1298.e12. [CrossRef]

41. Chen, R.; Wold, M.S. Replication Protein A: Single-Stranded DNA's First Responder: Dynamic DNA-Interactions Allow Replication Protein A to Direct Single-Strand DNA Intermediates into Different Pathways for Synthesis or Repair. Bioessays 2014, 36, 1156-1161. [CrossRef] [PubMed]

42. Taylor, M.S.; Altukhov, I.; Molloy, K.R.; Mita, P.; Jiang, H.; Adney, E.M.; Wudzinska, A.; Badri, S.; Ischenko, D.; Eng, G.; et al. Dissection of Affinity Captured LINE-1 Macromolecular Complexes. eLife 2018, 7, e30094. [CrossRef] [PubMed]

43. Taylor, M.S.; LaCava, J.; Mita, P.; Molloy, K.R.; Huang, C.R.L.; Li, D.; Adney, E.M.; Jiang, H.; Burns, K.H.; Chait, B.T.; et al. Affinity Proteomics Reveals Human Host Factors Implicated in Discrete Stages of LINE-1 Retrotransposition. Cell 2013, 155, 1034-1048. [CrossRef] [PubMed]

44. Gregersen, L.H.; Schueler, M.; Munschauer, M.; Mastrobuoni, G.; Chen, W.; Kempa, S.; Dieterich, C.; Landthaler, M. MOV10 Is a $5^{\prime}$ to $3^{\prime}$ RNA Helicase Contributing to UPF1 MRNA Target Degradation by Translocation along 3' UTRs. Mol. Cell 2014, 54, 573-585. [CrossRef] [PubMed] 
45. Coufal, N.G.; Garcia-Perez, J.L.; Peng, G.E.; Marchetto, M.C.N.; Muotri, A.R.; Mu, Y.; Carson, C.T.; Macia, A.; Moran, J.V.; Gage, F.H. Ataxia Telangiectasia Mutated (ATM) Modulates Long Interspersed Element-1 (L1) Retrotransposition in Human Neural Stem Cells. Proc. Natl. Acad. Sci. USA 2011, 108, 20382-20387. [CrossRef]

46. Suzuki, J.; Yamaguchi, K.; Kajikawa, M.; Ichiyanagi, K.; Adachi, N.; Koyama, H.; Takeda, S.; Okada, N. Genetic Evidence That the Non-Homologous End-Joining Repair Pathway Is Involved in LINE Retrotransposition. PLoS Genet. 2009, 5, e1000461. [CrossRef] [PubMed]

47. Zingler, N.; Willhoeft, U.; Brose, H.-P.; Schoder, V.; Jahns, T.; Hanschmann, K.-M.O.; Morrish, T.A.; Löwer, J.; Schumann, G.G. Analysis of 5' Junctions of Human LINE-1 and Alu Retrotransposons Suggests an Alternative Model for 5'-End Attachment Requiring Microhomology-Mediated End-Joining. Genome Res. 2005, 15, 780-789. [CrossRef]

48. Kopera, H.C.; Moldovan, J.B.; Morrish, T.A.; Garcia-Perez, J.L.; Moran, J.V. Similarities between Long Interspersed Element-1 (LINE-1) Reverse Transcriptase and Telomerase. Proc. Natl. Acad. Sci. USA 2011, 108, 20345-20350. [CrossRef]

49. Morrish, T.A.; Garcia-Perez, J.L.; Stamato, T.D.; Taccioli, G.E.; Sekiguchi, J.; Moran, J.V. Endonuclease-Independent LINE-1 Retrotransposition at Mammalian Telomeres. Nature 2007, 446, 208-212. [CrossRef]

50. Morrish, T.A.; Gilbert, N.; Myers, J.S.; Vincent, B.J.; Stamato, T.D.; Taccioli, G.E.; Batzer, M.A.; Moran, J.V. DNA Repair Mediated by Endonuclease-Independent LINE-1 Retrotransposition. Nat. Genet. 2002, 31, 159-165. [CrossRef]

51. Ohshima, K. Parallel Relaxation of Stringent RNA Recognition in Plant and Mammalian L1 Retrotransposons. Mol. Biol. Evol. 2012, 29, 3255-3259. [CrossRef]

52. Ivancevic, A.M.; Kortschak, R.D.; Bertozzi, T.; Adelson, D.L. LINEs between Species: Evolutionary Dynamics of LINE-1 Retrotransposons across the Eukaryotic Tree of Life. Genome Biol. Evol. 2016, 8, 3301-3322. [CrossRef]

53. Kordis, D.; Lovsin, N.; Gubensek, F. Phylogenomic Analysis of the L1 Retrotransposons in Deuterostomia. Syst. Biol. 2006, 55, 886-901. [CrossRef]

54. Chalopin, D.; Naville, M.; Plard, F.; Galiana, D.; Volff, J.-N. Comparative Analysis of Transposable Elements Highlights Mobilome Diversity and Evolution in Vertebrates. Genome Biol. Evol. 2015, 7, 567-580. [CrossRef] [PubMed]

55. Sotero-Caio, C.G.; Platt, R.N.; Suh, A.; Ray, D.A. Evolution and Diversity of Transposable Elements in Vertebrate Genomes. Genome Biol. Evol. 2017, 9, 161-177. [CrossRef] [PubMed]

56. Shao, F.; Han, M.; Peng, Z. Evolution and Diversity of Transposable Elements in Fish Genomes. Sci. Rep. 2019, 9, 15399. [CrossRef] [PubMed]

57. Metcalfe, C.J.; Filée, J.; Germon, I.; Joss, J.; Casane, D. Evolution of the Australian Lungfish (Neoceratodus Forsteri) Genome: A Major Role for CR1 and L2 LINE Elements. Mol. Biol. Evol. 2012, 29, 3529-3539. [CrossRef]

58. Nikaido, M.; Noguchi, H.; Nishihara, H.; Toyoda, A.; Suzuki, Y.; Kajitani, R.; Suzuki, H.; Okuno, M.; Aibara, M.; Ngatunga, B.P.; et al. Coelacanth Genomes Reveal Signatures for Evolutionary Transition from Water to Land. Genome Res. 2013, 23, 1740-1748. [CrossRef]

59. Luchetti, A.; Plazzi, F.; Mantovani, B. Evolution of Two Short Interspersed Elements in Callorhinchus milii (Chondrichthyes, Holocephali) and Related Elements in Sharks and the Coelacanth. Genome Biol. Evol. 2017, 9, 1406-1417. [CrossRef]

60. Meyer, A.; Schloissnig, S.; Franchini, P.; Du, K.; Woltering, J.M.; Irisarri, I.; Wong, W.Y.; Nowoshilow, S.; Kneitz, S.; Kawaguchi, A.; et al. Giant Lungfish Genome Elucidates the Conquest of Land by Vertebrates. Nature 2021, 590, 284-289. [CrossRef]

61. Venkatesh, B.; Lee, A.P.; Ravi, V.; Maurya, A.K.; Lian, M.M.; Swann, J.B.; Ohta, Y.; Flajnik, M.F.; Sutoh, Y.; Kasahara, M.; et al. Elephant Shark Genome Provides Unique Insights into Gnathostome Evolution. Nature 2014, 505, 174-179. [CrossRef] [PubMed]

62. Smith, J.J.; Kuraku, S.; Holt, C.; Sauka-Spengler, T.; Jiang, N.; Campbell, M.S.; Yandell, M.D.; Manousaki, T.; Meyer, A.; Bloom, O.E.; et al. Sequencing of the Sea Lamprey (Petromyzon Marinus) Genome Provides Insights into Vertebrate Evolution. Nat. Genet. 2013, 45, 415-421. [CrossRef]

63. Alföldi, J.; Di Palma, F.; Grabherr, M.; Williams, C.; Kong, L.; Mauceli, E.; Russell, P.; Lowe, C.B.; Glor, R.E.; Jaffe, J.D.; et al. The Genome of the Green Anole Lizard and a Comparative Analysis with Birds and Mammals. Nature 2011, 477, 587-591. [CrossRef] [PubMed]

64. Boissinot, S.; Sookdeo, A. The Evolution of LINE-1 in Vertebrates. Genome Biol. Evol. 2016, 8, 3485-3507. [CrossRef] [PubMed]

65. Suh, A.; Churakov, G.; Ramakodi, M.P.; Platt, R.N.; Jurka, J.; Kojima, K.K.; Caballero, J.; Smit, A.F.; Vliet, K.A.; Hoffmann, F.G.; et al. Multiple Lineages of Ancient CR1 Retroposons Shaped the Early Genome Evolution of Amniotes. Genome Biol. Evol. 2014, 7 , 205-217. [CrossRef] [PubMed]

66. Pasquesi, G.I.M.; Adams, R.H.; Card, D.C.; Schield, D.R.; Corbin, A.B.; Perry, B.W.; Reyes-Velasco, J.; Ruggiero, R.P.; Vandewege, M.W.; Shortt, J.A.; et al. Squamate Reptiles Challenge Paradigms of Genomic Repeat Element Evolution Set by Birds and Mammals. Nat. Commun. 2018, 9, 2774. [CrossRef] [PubMed]

67. Boissinot, S.; Bourgeois, Y.; Manthey, J.D.; Ruggiero, R.P. The Mobilome of Reptiles: Evolution, Structure, and Function. Cytogenet. Genome Res. 2019, 157, 21-33. [CrossRef]

68. Gemmell, N.J.; Rutherford, K.; Prost, S.; Tollis, M.; Winter, D.; Macey, J.R.; Adelson, D.L.; Suh, A.; Bertozzi, T.; Grau, J.H.; et al. The Tuatara Genome Reveals Ancient Features of Amniote Evolution. Nature 2020, 584, 403-409. [CrossRef]

69. Shedlock, A.M. Phylogenomic Investigation of CR1 LINE Diversity in Reptiles. Syst. Biol. 2006, 55, 902-911. [CrossRef]

70. Suh, A. The Specific Requirements for CR1 Retrotransposition Explain the Scarcity of Retrogenes in Birds. J. Mol. Evol. 2015, 81, 18-20. [CrossRef] 
71. Kapusta, A.; Suh, A. Evolution of Bird Genomes-a Transposon's-Eye View. Ann. N. Y. Acad. Sci. 2017, 1389, 164-185. [CrossRef] [PubMed]

72. Smit, A.F.; Tóth, G.; Riggs, A.D.; Jurka, J. Ancestral, Mammalian-Wide Subfamilies of LINE-1 Repetitive Sequences. J. Mol. Biol. 1995, 246, 401-417. [CrossRef] [PubMed]

73. Warren, W.C.; Hillier, L.W.; Marshall Graves, J.A.; Birney, E.; Ponting, C.P.; Grützner, F.; Belov, K.; Miller, W.; Clarke, L.; Chinwalla, A.T.; et al. Genome Analysis of the Platypus Reveals Unique Signatures of Evolution. Nature 2008, 453, 175-183. [CrossRef] [PubMed]

74. Mikkelsen, T.S.; Wakefield, M.J.; Aken, B.; Amemiya, C.T.; Chang, J.L.; Duke, S.; Garber, M.; Gentles, A.J.; Goodstadt, L.; Heger, A.; et al. Genome of the Marsupial Monodelphis Domestica Reveals Innovation in Non-Coding Sequences. Nature 2007, 447, 167-177. [CrossRef]

75. Polychronopoulos, D.; King, J.W.D.; Nash, A.J.; Tan, G.; Lenhard, B. Conserved Non-Coding Elements: Developmental Gene Regulation Meets Genome Organization. Nucleic Acids Res. 2017, 45, 12611-12624. [CrossRef]

76. Wichman, H.A.; Scott, L.; Howell, E.K.; Martinez, A.R.; Yang, L.; Baker, R.J. Flying Around in the Genome: Characterization of LINE-1 in Chiroptera. Spec. Publ. Tex. Tech. Univ. Mus. 2019, 71, 379-392.

77. Platt, R.N.; Ray, D.A. A Non-LTR Retroelement Extinction in Spermophilus Tridecemlineatus. Gene 2012, 500, 47-53. [CrossRef]

78. Sookdeo, A.; Hepp, C.M.; Boissinot, S. Contrasted Patterns of Evolution of the LINE-1 Retrotransposon in Perissodactyls: The History of a LINE-1 Extinction. Mob. DNA 2018, 9, 12. [CrossRef]

79. Yang, L.; Scott, L.; Wichman, H.A. Tracing the History of LINE and SINE Extinction in Sigmodontine Rodents. Mob. DNA 2019, 10, 22. [CrossRef]

80. Blumenstiel, J.P. Birth, School, Work, Death, and Resurrection: The Life Stages and Dynamics of Transposable Element Proliferation. Genes 2019, 10, 336. [CrossRef] [PubMed]

81. Mouse Genome Sequencing Consortium; Waterston, R.H.; Lindblad-Toh, K.; Birney, E.; Rogers, J.; Abril, J.F.; Agarwal, P.; Agarwala, R.; Ainscough, R.; Alexandersson, M.; et al. Initial Sequencing and Comparative Analysis of the Mouse Genome. Nature 2002, 420, 520-562. [CrossRef]

82. Gibbs, R.A.; Weinstock, G.M.; Metzker, M.L.; Muzny, D.M.; Sodergren, E.J.; Scherer, S.; Scott, G.; Steffen, D.; Worley, K.C.; Burch, P.E.; et al. Genome Sequence of the Brown Norway Rat Yields Insights into Mammalian Evolution. Nature 2004, 428, 493-521. [CrossRef]

83. Glazko, G.V.; Nei, M. Estimation of Divergence Times for Major Lineages of Primate Species. Mol. Biol. Evol. 2003, 20, 424-434. [CrossRef]

84. Chatterjee, H.J.; Ho, S.Y.W.; Barnes, I.; Groves, C. Estimating the Phylogeny and Divergence Times of Primates Using a Supermatrix Approach. BMC Evol. Biol. 2009, 9, 259. [CrossRef]

85. Konkel, M.K.; Walker, J.A.; Batzer, M.A. LINEs and SINEs of Primate Evolution. Evol. Anthropol. 2010, 19, 236-249. [CrossRef] [PubMed]

86. Tang, W.; Liang, P. Comparative Genomics Analysis Reveals High Levels of Differential Retrotransposition among Primates from the Hominidae and the Cercopithecidae Families. Genome Biol. Evol. 2019, 11, 3309-3325. [CrossRef]

87. Boissinot, S.; Roos, C.; Furano, A.V. Different Rates of LINE-1 (L1) Retrotransposon Amplification and Evolution in New World Monkeys. J. Mol. Evol. 2004, 58, 122-130. [CrossRef]

88. Sookdeo, A.; Ruiz-García, M.; Schneider, H.; Boissinot, S. Contrasting Rates of LINE-1 Amplification among New World Primates of the Atelidae Family. Cytogenet. Genome Res. 2018, 154, 217-228. [CrossRef]

89. Han, K.; Konkel, M.K.; Xing, J.; Wang, H.; Lee, J.; Meyer, T.J.; Huang, C.T.; Sandifer, E.; Hebert, K.; Barnes, E.W.; et al. Mobile DNA in Old World Monkeys: A Glimpse through the Rhesus Macaque Genome. Science 2007, 316, 238-240. [CrossRef] [PubMed]

90. Lee, S.; Tang, W.; Liang, P.; Han, K. A Comprehensive Analysis of Chimpanzee (Pan Troglodytes)-Specific LINE-1 Retrotransposons. Gene 2019, 693, 46-51. [CrossRef] [PubMed]

91. Fernandes, J.D.; Zamudio-Hurtado, A.; Clawson, H.; Kent, W.J.; Haussler, D.; Salama, S.R.; Haeussler, M. The UCSC Repeat Browser Allows Discovery and Visualization of Evolutionary Conflict across Repeat Families. Mob. DNA 2020, 11, 13. [CrossRef]

92. Castellano, D.; Munch, K. Population Genomics in the Great Apes. Methods Mol. Biol. 2020, 2090, 453-463. [CrossRef]

93. Jeon, S.; Kim, S.; Oh, M.H.; Liang, P.; Tang, W.; Han, K. A Comprehensive Analysis of Gorilla-Specific LINE-1 Retrotransposons. Genes Genom. 2021, 43, 1133-1141. [CrossRef] [PubMed]

94. Lee, J.; Cordaux, R.; Han, K.; Wang, J.; Hedges, D.J.; Liang, P.; Batzer, M.A. Different Evolutionary Fates of Recently Integrated Human and Chimpanzee LINE-1 Retrotransposons. Gene 2007, 390, 18-27. [CrossRef]

95. Beck, C.R.; Collier, P.; Macfarlane, C.; Malig, M.; Kidd, J.M.; Eichler, E.E.; Badge, R.M.; Moran, J.V. LINE-1 Retrotransposition Activity in Human Genomes. Cell 2010, 141, 1159-1170. [CrossRef] [PubMed]

96. Cordaux, R.; Batzer, M.A. The Impact of Retrotransposons on Human Genome Evolution. Nat. Rev. Genet. 2009, 10, 691-703. [CrossRef] [PubMed]

97. Richardson, S.R.; Doucet, A.J.; Kopera, H.C.; Moldovan, J.B.; Garcia-Perez, J.L.; Moran, J.V. The Influence of LINE-1 and SINE Retrotransposons on Mammalian Genomes. Microbiol. Spectr. 2015, 3, MDNA3-0061-2014. [CrossRef]

98. Gardner, E.J.; Lam, V.K.; Harris, D.N.; Chuang, N.T.; Scott, E.C.; Pittard, W.S.; Mills, R.E.; 1000 Genomes Project Consortium; Devine, S.E. The Mobile Element Locator Tool (MELT): Population-Scale Mobile Element Discovery and Biology. Genome Res. 2017, 27, 1916-1929. [CrossRef] 
99. Guichard, E.; Peona, V.; Malagoli Tagliazucchi, G.; Abitante, L.; Jagoda, E.; Musella, M.; Ricci, M.; Rubio-Roldán, A.; Sarno, S.; Luiselli, D.; et al. Impact of Non-LTR Retrotransposons in the Differentiation and Evolution of Anatomically Modern Humans. Mob. DNA 2018, 9, 28. [CrossRef]

100. Rishishwar, L.; Tellez Villa, C.E.; Jordan, I.K. Transposable Element Polymorphisms Recapitulate Human Evolution. Mob. DNA 2015, 6, 21. [CrossRef]

101. Watkins, W.S.; Feusier, J.E.; Thomas, J.; Goubert, C.; Mallick, S.; Jorde, L.B. The Simons Genome Diversity Project: A Global Analysis of Mobile Element Diversity. Genome Biol. Evol. 2020, 12, 779-794. [CrossRef]

102. Ito, J.; Gifford, R.J.; Sato, K. Retroviruses Drive the Rapid Evolution of Mammalian APOBEC3 Genes. Proc. Natl. Acad. Sci. USA 2020, 117, 610-618. [CrossRef] [PubMed]

103. Uriu, K.; Kosugi, Y.; Ito, J.; Sato, K. The Battle between Retroviruses and APOBEC3 Genes: Its Past and Present. Viruses 2021, 13, 124. [CrossRef] [PubMed]

104. Hayward, J.A.; Tachedjian, M.; Cui, J.; Cheng, A.Z.; Johnson, A.; Baker, M.L.; Harris, R.S.; Wang, L.-F.; Tachedjian, G. Differential Evolution of Antiretroviral Restriction Factors in Pteropid Bats as Revealed by APOBEC3 Gene Complexity. Mol. Biol. Evol. 2018, 35, 1626-1637. [CrossRef] [PubMed]

105. Yang, L.; Emerman, M.; Malik, H.S.; McLaughlin, R.N. Retrocopying Expands the Functional Repertoire of APOBEC3 Antiviral Proteins in Primates. eLife 2020, 9, e58436. [CrossRef]

106. Uriu, K.; Kosugi, Y.; Suzuki, N.; Ito, J.; Sato, K. Elucidation of the Complicated Scenario of Primate APOBEC3 Gene Evolution. J. Virol. 2021, 95, e00144-21. [CrossRef] [PubMed]

107. Harris, R.S.; Dudley, J.P. APOBECs and Virus Restriction. Virology 2015, 479-480, 131-145. [CrossRef] [PubMed]

108. Parhad, S.S.; Theurkauf, W.E. Rapid Evolution and Conserved Function of the PiRNA Pathway. Open Biol. $2019,9,180181$. [CrossRef]

109. Castro-Diaz, N.; Ecco, G.; Coluccio, A.; Kapopoulou, A.; Yazdanpanah, B.; Friedli, M.; Duc, J.; Jang, S.M.; Turelli, P.; Trono, D. Evolutionally Dynamic L1 Regulation in Embryonic Stem Cells. Genes Dev. 2014, 28, 1397-1409. [CrossRef]

110. Sanchez-Luque, F.J.; Kempen, M.-J.H.C.; Gerdes, P.; Vargas-Landin, D.B.; Richardson, S.R.; Troskie, R.-L.; Jesuadian, J.S.; Cheetham, S.W.; Carreira, P.E.; Salvador-Palomeque, C.; et al. LINE-1 Evasion of Epigenetic Repression in Humans. Mol. Cell 2019, 75, 590-604.e12. [CrossRef]

111. Douse, C.H.; Tchasovnikarova, I.A.; Timms, R.T.; Protasio, A.V.; Seczynska, M.; Prigozhin, D.M.; Albecka, A.; Wagstaff, J.; Williamson, J.C.; Freund, S.M.V.; et al. TASOR Is a Pseudo-PARP That Directs HUSH Complex Assembly and Epigenetic Transposon Control. Nat. Commun. 2020, 11, 4940. [CrossRef] [PubMed]

112. Marchetto, M.C.N.; Narvaiza, I.; Denli, A.M.; Benner, C.; Lazzarini, T.A.; Nathanson, J.L.; Paquola, A.C.M.; Desai, K.N.; Herai, R.H.; Weitzman, M.D.; et al. Differential L1 Regulation in Pluripotent Stem Cells of Humans and Apes. Nature 2013, 503, 525-529. [CrossRef] [PubMed]

113. Muotri, A.R.; Chu, V.T.; Marchetto, M.C.N.; Deng, W.; Moran, J.V.; Gage, F.H. Somatic Mosaicism in Neuronal Precursor Cells Mediated by L1 Retrotransposition. Nature 2005, 435, 903-910. [CrossRef] [PubMed]

114. Liao, J.; Karnik, R.; Gu, H.; Ziller, M.J.; Clement, K.; Tsankov, A.M.; Akopian, V.; Gifford, C.A.; Donaghey, J.; Galonska, C.; et al. Targeted Disruption of DNMT1, DNMT3A and DNMT3B in Human Embryonic Stem Cells. Nat. Genet. 2015, 47, 469-478. [CrossRef]

115. Hatanaka, Y.; Inoue, K.; Oikawa, M.; Kamimura, S.; Ogonuki, N.; Kodama, E.N.; Ohkawa, Y.; Tsukada, Y.; Ogura, A. Histone Chaperone CAF-1 Mediates Repressive Histone Modifications to Protect Preimplantation Mouse Embryos from Endogenous Retrotransposons. Proc. Natl. Acad. Sci. USA 2015, 112, 14641-14646. [CrossRef]

116. He, J.; Fu, X.; Zhang, M.; He, F.; Li, W.; Abdul, M.M.; Zhou, J.; Sun, L.; Chang, C.; Li, Y.; et al. Transposable Elements Are Regulated by Context-Specific Patterns of Chromatin Marks in Mouse Embryonic Stem Cells. Nat. Commun. 2019, 10, 34. [CrossRef]

117. Silverman, R.H. Viral Encounters with $2^{\prime}, 5^{\prime}$-Oligoadenylate Synthetase and RNase L during the Interferon Antiviral Response. J. Virol. 2007, 81, 12720-12729. [CrossRef]

118. Yao, Q.; Cao, G.; Li, M.; Wu, B.; Zhang, X.; Zhang, T.; Guo, J.; Yin, H.; Shi, L.; Chen, J.; et al. Ribonuclease Activity of MARF1 Controls Oocyte RNA Homeostasis and Genome Integrity in Mice. Proc. Natl. Acad. Sci. USA 2018, 115, 11250-11255. [CrossRef]

119. Orecchini, E.; Frassinelli, L.; Galardi, S.; Ciafrè, S.A.; Michienzi, A. Post-Transcriptional Regulation of LINE-1 Retrotransposition by AID/APOBEC and ADAR Deaminases. Chromosome Res. 2018, 26, 45-59. [CrossRef]

120. Goodier, J.L.; Pereira, G.C.; Cheung, L.E.; Rose, R.J.; Kazazian, H.H. The Broad-Spectrum Antiviral Protein ZAP Restricts Human Retrotransposition. PLoS Genet. 2015, 11, e1005252. [CrossRef]

121. Herrmann, A.; Wittmann, S.; Thomas, D.; Shepard, C.N.; Kim, B.; Ferreirós, N.; Gramberg, T. The SAMHD1-Mediated Block of LINE-1 Retroelements Is Regulated by Phosphorylation. Mob. DNA 2018, 9, 11. [CrossRef]

122. Guo, L.; Byun, H.-M.; Zhong, J.; Motta, V.; Barupal, J.; Zheng, Y.; Dou, C.; Zhang, F.; McCracken, J.P.; Diaz, A.; et al. Effects of Short-Term Exposure to Inhalable Particulate Matter on DNA Methylation of Tandem Repeats. Environ. Mol. Mutagen. 2014, 55, 322-335. [CrossRef]

123. Gasior, S.L.; Roy-Engel, A.M.; Deininger, P.L. ERCC1/XPF Limits L1 Retrotransposition. DNA Repair. (Amst.) 2008, 7, 983-989. [CrossRef]

124. Servant, G.; Streva, V.A.; Derbes, R.S.; Wijetunge, M.I.; Neeland, M.; White, T.B.; Belancio, V.P.; Roy-Engel, A.M.; Deininger, P.L. The Nucleotide Excision Repair Pathway Limits L1 Retrotransposition. Genetics 2017, 205, 139-153. [CrossRef] [PubMed] 
125. Pizarro, J.G.; Cristofari, G. Post-Transcriptional Control of LINE-1 Retrotransposition by Cellular Host Factors in Somatic Cells. Front. Cell Dev. Biol. 2016, 4, 14. [CrossRef]

126. Mita, P.; Sun, X.; Fenyö, D.; Kahler, D.J.; Li, D.; Agmon, N.; Wudzinska, A.; Keegan, S.; Bader, J.S.; Yun, C.; et al. BRCA1 and S Phase DNA Repair Pathways Restrict LINE-1 Retrotransposition in Human Cells. Nat. Struct. Mol. Biol. 2020, $27,179-191$. [CrossRef]

127. Aravin, A.A.; Hannon, G.J.; Brennecke, J. The Piwi-PiRNA Pathway Provides an Adaptive Defense in the Transposon Arms Race. Science 2007, 318, 761-764. [CrossRef]

128. Hancks, D.C.; Kazazian, H.H. Roles for Retrotransposon Insertions in Human Disease. Mob. DNA 2016, 7, 9. [CrossRef] [PubMed]

129. Kohlrausch, F.B.; Berteli, T.S.; Wang, F.; Navarro, P.A.; Keefe, D.L. Control of LINE-1 Expression Maintains Genome Integrity in Germline and Early Embryo Development. Reprod. Sci. 2021. [CrossRef] [PubMed]

130. Kim, S.; Günesdogan, U.; Zylicz, J.J.; Hackett, J.A.; Cougot, D.; Bao, S.; Lee, C.; Dietmann, S.; Allen, G.E.; Sengupta, R.; et al. PRMT5 Protects Genomic Integrity during Global DNA Demethylation in Primordial Germ Cells and Preimplantation Embryos. Mol. Cell 2014, 56, 564-579. [CrossRef]

131. Wu, Y.; Liu, W.; Chen, J.; Liu, S.; Wang, M.; Yang, L.; Chen, C.; Qi, M.; Xu, Y.; Qiao, Z.; et al. Nuclear Exosome Targeting Complex Core Factor Zcchc8 Regulates the Degradation of LINE1 RNA in Early Embryos and Embryonic Stem Cells. Cell Rep. 2019, 29, 2461-2472.e6. [CrossRef]

132. Lees-Murdock, D.J.; Walsh, C.P. DNA Methylation Reprogramming in the Germ Line. Adv. Exp. Med. Biol. 2008, 626, 1-15. [CrossRef]

133. Smith, Z.D.; Chan, M.M.; Mikkelsen, T.S.; Gu, H.; Gnirke, A.; Regev, A.; Meissner, A. A Unique Regulatory Phase of DNA Methylation in the Early Mammalian Embryo. Nature 2012, 484, 339-344. [CrossRef]

134. De Iaco, A.; Coudray, A.; Duc, J.; Trono, D. DPPA2 and DPPA4 Are Necessary to Establish a 2C-like State in Mouse Embryonic Stem Cells. EMBO Rep. 2019, 20, e47382. [CrossRef]

135. Kazazian, H.H.; Moran, J.V. Mobile DNA in Health and Disease. N. Engl. J. Med. 2017, 377, 361-370. [CrossRef]

136. Protasova, M.S.; Gusev, F.E.; Grigorenko, A.P.; Kuznetsova, I.L.; Rogaev, E.I.; Andreeva, T.V. Quantitative Analysis of L1Retrotransposons in Alzheimer's Disease and Aging. Biochemistry 2017, 82, 962-971. [CrossRef]

137. Kano, H.; Godoy, I.; Courtney, C.; Vetter, M.R.; Gerton, G.L.; Ostertag, E.M.; Kazazian, H.H. L1 Retrotransposition Occurs Mainly in Embryogenesis and Creates Somatic Mosaicism. Genes Dev. 2009, 23, 1303-1312. [CrossRef]

138. Baillie, J.K.; Barnett, M.W.; Upton, K.R.; Gerhardt, D.J.; Richmond, T.A.; De Sapio, F.; Brennan, P.M.; Rizzu, P.; Smith, S.; Fell, M.; et al. Somatic Retrotransposition Alters the Genetic Landscape of the Human Brain. Nature 2011, 479, 534-537. [CrossRef] [PubMed]

139. Coufal, N.G.; Garcia-Perez, J.L.; Peng, G.E.; Yeo, G.W.; Mu, Y.; Lovci, M.T.; Morell, M.; O’Shea, K.S.; Moran, J.V.; Gage, F.H. L1 Retrotransposition in Human Neural Progenitor Cells. Nature 2009, 460, 1127-1131. [CrossRef] [PubMed]

140. Li, E.; Bestor, T.H.; Jaenisch, R. Targeted Mutation of the DNA Methyltransferase Gene Results in Embryonic Lethality. Cell 1992, 69, 915-926. [CrossRef]

141. Okano, M.; Bell, D.W.; Haber, D.A.; Li, E. DNA Methyltransferases Dnmt3a and Dnmt3b Are Essential for de Novo Methylation and Mammalian Development. Cell 1999, 99, 247-257. [CrossRef]

142. Gretarsson, K.H.; Hackett, J.A. Dppa2 and Dppa4 Counteract de Novo Methylation to Establish a Permissive Epigenome for Development. Nat. Struct. Mol. Biol. 2020, 27, 706-716. [CrossRef]

143. Peaston, A.E.; Evsikov, A.V.; Graber, J.H.; de Vries, W.N.; Holbrook, A.E.; Solter, D.; Knowles, B.B. Retrotransposons Regulate Host Genes in Mouse Oocytes and Preimplantation Embryos. Dev. Cell 2004, 7, 597-606. [CrossRef]

144. Fadloun, A.; Le Gras, S.; Jost, B.; Ziegler-Birling, C.; Takahashi, H.; Gorab, E.; Carninci, P.; Torres-Padilla, M.-E. Chromatin Signatures and Retrotransposon Profiling in Mouse Embryos Reveal Regulation of LINE-1 by RNA. Nat. Struct. Mol. Biol. 2013, 20, 332-338. [CrossRef]

145. Jachowicz, J.W.; Bing, X.; Pontabry, J.; Bošković, A.; Rando, O.J.; Torres-Padilla, M.-E. LINE-1 Activation after Fertilization Regulates Global Chromatin Accessibility in the Early Mouse Embryo. Nat. Genet. 2017, 49, 1502-1510. [CrossRef]

146. Percharde, M.; Lin, C.-J.; Yin, Y.; Guan, J.; Peixoto, G.A.; Bulut-Karslioglu, A.; Biechele, S.; Huang, B.; Shen, X.; Ramalho-Santos, M. A LINE1-Nucleolin Partnership Regulates Early Development and ESC Identity. Cell 2018, 174, 391-405.e19. [CrossRef]

147. Bulut-Karslioglu, A.; De La Rosa-Velázquez, I.A.; Ramirez, F.; Barenboim, M.; Onishi-Seebacher, M.; Arand, J.; Galán, C.; Winter, G.E.; Engist, B.; Gerle, B.; et al. Suv39h-Dependent H3K9me3 Marks Intact Retrotransposons and Silences LINE Elements in Mouse Embryonic Stem Cells. Mol. Cell 2014, 55, 277-290. [CrossRef]

148. Tachibana, M.; Sugimoto, K.; Nozaki, M.; Ueda, J.; Ohta, T.; Ohki, M.; Fukuda, M.; Takeda, N.; Niida, H.; Kato, H.; et al. G9a Histone Methyltransferase Plays a Dominant Role in Euchromatic Histone H3 Lysine 9 Methylation and Is Essential for Early Embryogenesis. Genes Dev. 2002, 16, 1779-1791. [CrossRef] [PubMed]

149. Matsui, T.; Leung, D.; Miyashita, H.; Maksakova, I.A.; Miyachi, H.; Kimura, H.; Tachibana, M.; Lorincz, M.C.; Shinkai, Y. Proviral Silencing in Embryonic Stem Cells Requires the Histone Methyltransferase ESET. Nature 2010, 464, 927-931. [CrossRef] [PubMed]

150. Karimi, M.M.; Goyal, P.; Maksakova, I.A.; Bilenky, M.; Leung, D.; Tang, J.X.; Shinkai, Y.; Mager, D.L.; Jones, S.; Hirst, M.; et al. DNA Methylation and SETDB1/H3K9me3 Regulate Predominantly Distinct Sets of Genes, Retroelements, and Chimeric Transcripts in MESCs. Cell Stem Cell 2011, 8, 676-687. [CrossRef] [PubMed] 
151. Peters, A.H.; O'Carroll, D.; Scherthan, H.; Mechtler, K.; Sauer, S.; Schöfer, C.; Weipoltshammer, K.; Pagani, M.; Lachner, M.; Kohlmaier, A.; et al. Loss of the Suv39h Histone Methyltransferases Impairs Mammalian Heterochromatin and Genome Stability. Cell 2001, 107, 323-337. [CrossRef]

152. Rao, V.K.; Pal, A.; Taneja, R. A Drive in SUVs: From Development to Disease. Epigenetics 2017, 12, 177-186. [CrossRef]

153. Robbez-Masson, L.; Tie, C.H.C.; Conde, L.; Tunbak, H.; Husovsky, C.; Tchasovnikarova, I.A.; Timms, R.T.; Herrero, J.; Lehner, P.J.; Rowe, H.M. The HUSH Complex Cooperates with TRIM28 to Repress Young Retrotransposons and New Genes. Genome Res. 2018, 28, 836-845. [CrossRef]

154. Müller, I.; Moroni, A.S.; Shlyueva, D.; Sahadevan, S.; Schoof, E.M.; Radzisheuskaya, A.; Højfeldt, J.W.; Tatar, T.; Koche, R.P.; Huang, C.; et al. MPP8 Is Essential for Sustaining Self-Renewal of Ground-State Pluripotent Stem Cells. Nat. Commun. 2021, 12, 3034. [CrossRef]

155. Harten, S.K.; Bruxner, T.J.; Bharti, V.; Blewitt, M.; Nguyen, T.-M.-T.; Whitelaw, E.; Epp, T. The First Mouse Mutants of D14Abb1e (Fam208a) Show That It Is Critical for Early Development. Mamm. Genome 2014, 25, 293-303. [CrossRef] [PubMed]

156. Dai, Q.; Shen, Y.; Wang, Y.; Wang, X.; Francisco, J.C.; Luo, Z.; Lin, C. Striking a Balance: Regulation of Transposable Elements by Zfp281 and Mll2 in Mouse Embryonic Stem Cells. Nucleic Acids Res. 2017, 45, 12301-12310. [CrossRef]

157. Achwal, C.W.; Iyer, C.A.; Chandra, H.S. Immunochemical Evidence for the Presence of 5mC, $6 \mathrm{~mA}$ and $7 \mathrm{mG}$ in Human, Drosophila and Mealybug DNA. FEBS Lett. 1983, 158, 353-358. [CrossRef]

158. Ratel, D.; Ravanat, J.-L.; Berger, F.; Wion, D. N6-Methyladenine: The Other Methylated Base of DNA. Bioessays 2006, 28, 309-315. [CrossRef]

159. Wu, T.P.; Wang, T.; Seetin, M.G.; Lai, Y.; Zhu, S.; Lin, K.; Liu, Y.; Byrum, S.D.; Mackintosh, S.G.; Zhong, M.; et al. DNA Methylation on N(6)-Adenine in Mammalian Embryonic Stem Cells. Nature 2016, 532, 329-333. [CrossRef] [PubMed]

160. Adhikari, S.; Xiao, W.; Zhao, Y.-L.; Yang, Y.-G. M(6)A: Signaling for MRNA Splicing. RNA Biol. 2016, 13, 756-759. [CrossRef] [PubMed]

161. Liu, J.; Gao, M.; He, J.; Wu, K.; Lin, S.; Jin, L.; Chen, Y.; Liu, H.; Shi, J.; Wang, X.; et al. The RNA M6A Reader YTHDC1 Silences Retrotransposons and Guards ES Cell Identity. Nature 2021, 591, 322-326. [CrossRef]

162. Chen, C.; Liu, W.; Guo, J.; Liu, Y.; Liu, X.; Liu, J.; Dou, X.; Le, R.; Huang, Y.; Li, C.; et al. Nuclear M6A Reader YTHDC1 Regulates the Scaffold Function of LINE1 RNA in Mouse ESCs and Early Embryos. Protein Cell 2021, 12, 455-474. [CrossRef] [PubMed]

163. Xu, Q.; Xie, W. Epigenome in Early Mammalian Development: Inheritance, Reprogramming and Establishment. Trends Cell Biol. 2018, 28, 237-253. [CrossRef] [PubMed]

164. Matsui, Y.; Okamura, D. Mechanisms of Germ-Cell Specification in Mouse Embryos. Bioessays 2005, 27, 136-143. [CrossRef]

165. Ginsburg, M.; Snow, M.H.; McLaren, A. Primordial Germ Cells in the Mouse Embryo during Gastrulation. Development 1990, 110, 521-528. [CrossRef]

166. Sato, M.; Kimura, T.; Kurokawa, K.; Fujita, Y.; Abe, K.; Masuhara, M.; Yasunaga, T.; Ryo, A.; Yamamoto, M.; Nakano, T. Identification of PGC7, a New Gene Expressed Specifically in Preimplantation Embryos and Germ Cells. Mech. Dev. 2002, 113, 91-94. [CrossRef]

167. Saitou, M.; Barton, S.C.; Surani, M.A. A Molecular Programme for the Specification of Germ Cell Fate in Mice. Nature 2002, 418, 293-300. [CrossRef] [PubMed]

168. Lou, C.; Goodier, J.L.; Qiang, R. A Potential New Mechanism for Pregnancy Loss: Considering the Role of LINE-1 Retrotransposons in Early Spontaneous Miscarriage. Reprod. Biol. Endocrinol. 2020, 18, 6. [CrossRef] [PubMed]

169. Seisenberger, S.; Andrews, S.; Krueger, F.; Arand, J.; Walter, J.; Santos, F.; Popp, C.; Thienpont, B.; Dean, W.; Reik, W. The Dynamics of Genome-Wide DNA Methylation Reprogramming in Mouse Primordial Germ Cells. Mol. Cell 2012, 48, 849-862. [CrossRef]

170. Guibert, S.; Forné, T.; Weber, M. Global Profiling of DNA Methylation Erasure in Mouse Primordial Germ Cells. Genome Res. 2012, 22, 633-641. [CrossRef]

171. Kobayashi, H.; Sakurai, T.; Miura, F.; Imai, M.; Mochiduki, K.; Yanagisawa, E.; Sakashita, A.; Wakai, T.; Suzuki, Y.; Ito, T.; et al. High-Resolution DNA Methylome Analysis of Primordial Germ Cells Identifies Gender-Specific Reprogramming in Mice. Genome Res. 2013, 23, 616-627. [CrossRef]

172. Bourc'his, D.; Bestor, T.H. Meiotic Catastrophe and Retrotransposon Reactivation in Male Germ Cells Lacking Dnmt3L. Nature 2004, 431, 96-99. [CrossRef]

173. Kato, Y.; Kaneda, M.; Hata, K.; Kumaki, K.; Hisano, M.; Kohara, Y.; Okano, M.; Li, E.; Nozaki, M.; Sasaki, H. Role of the Dnmt3 Family in de Novo Methylation of Imprinted and Repetitive Sequences during Male Germ Cell Development in the Mouse. Hum. Mol. Genet. 2007, 16, 2272-2280. [CrossRef]

174. Barau, J.; Teissandier, A.; Zamudio, N.; Roy, S.; Nalesso, V.; Hérault, Y.; Guillou, F.; Bourc'his, D. The DNA Methyltransferase DNMT3C Protects Male Germ Cells from Transposon Activity. Science 2016, 354, 909-912. [CrossRef]

175. Jansz, N. DNA Methylation Dynamics at Transposable Elements in Mammals. Essays Biochem. 2019, 63, 677-689. [CrossRef]

176. Stewart, K.R.; Veselovska, L.; Kelsey, G. Establishment and Functions of DNA Methylation in the Germline. Epigenomics 2016, 8 , 1399-1413. [CrossRef]

177. Hajkova, P.; Erhardt, S.; Lane, N.; Haaf, T.; El-Maarri, O.; Reik, W.; Walter, J.; Surani, M.A. Epigenetic Reprogramming in Mouse Primordial Germ Cells. Mech. Dev. 2002, 117, 15-23. [CrossRef]

178. Lees-Murdock, D.J.; De Felici, M.; Walsh, C.P. Methylation Dynamics of Repetitive DNA Elements in the Mouse Germ Cell Lineage. Genomics 2003, 82, 230-237. [CrossRef] 
179. Pezic, D.; Manakov, S.A.; Sachidanandam, R.; Aravin, A.A. PiRNA Pathway Targets Active LINE1 Elements to Establish the Repressive H3K9me3 Mark in Germ Cells. Genes Dev. 2014, 28, 1410-1428. [CrossRef] [PubMed]

180. Aravin, A.A.; Sachidanandam, R.; Bourc'his, D.; Schaefer, C.; Pezic, D.; Toth, K.F.; Bestor, T.; Hannon, G.J. A PiRNA Pathway Primed by Individual Transposons Is Linked to de Novo DNA Methylation in Mice. Mol. Cell 2008, 31, 785-799. [CrossRef] [PubMed]

181. Gainetdinov, I.; Colpan, C.; Arif, A.; Cecchini, K.; Zamore, P.D. A Single Mechanism of Biogenesis, Initiated and Directed by PIWI Proteins, Explains PiRNA Production in Most Animals. Mol. Cell 2018, 71, 775-790.e5. [CrossRef]

182. Cox, D.N.; Chao, A.; Baker, J.; Chang, L.; Qiao, D.; Lin, H. A Novel Class of Evolutionarily Conserved Genes Defined by Piwi Are Essential for Stem Cell Self-Renewal. Genes Dev. 1998, 12, 3715-3727. [CrossRef] [PubMed]

183. Ross, R.J.; Weiner, M.M.; Lin, H. PIWI Proteins and PIWI-Interacting RNAs in the Soma. Nature 2014, 505, 353-359. [CrossRef] [PubMed]

184. Kim, K.W. PIWI Proteins and PiRNAs in the Nervous System. Mol. Cells 2019, 42, 828-835. [CrossRef]

185. Kuramochi-Miyagawa, S.; Watanabe, T.; Gotoh, K.; Totoki, Y.; Toyoda, A.; Ikawa, M.; Asada, N.; Kojima, K.; Yamaguchi, Y.; Ijiri, T.W.; et al. DNA Methylation of Retrotransposon Genes Is Regulated by Piwi Family Members MILI and MIWI2 in Murine Fetal Testes. Genes Dev. 2008, 22, 908-917. [CrossRef]

186. Manakov, S.A.; Pezic, D.; Marinov, G.K.; Pastor, W.A.; Sachidanandam, R.; Aravin, A.A. MIWI2 and MILI Have Differential Effects on PiRNA Biogenesis and DNA Methylation. Cell Rep. 2015, 12, 1234-1243. [CrossRef]

187. Vagin, V.V.; Wohlschlegel, J.; Qu, J.; Jonsson, Z.; Huang, X.; Chuma, S.; Girard, A.; Sachidanandam, R.; Hannon, G.J.; Aravin, A.A. Proteomic Analysis of Murine Piwi Proteins Reveals a Role for Arginine Methylation in Specifying Interaction with Tudor Family Members. Genes Dev. 2009, 23, 1749-1762. [CrossRef] [PubMed]

188. Nie, Y.; Wilson, A.F.; DeFalco, T.; Meetei, A.R.; Namekawa, S.H.; Pang, Q. FANCD2 Is Required for the Repression of Germline Transposable Elements. Reproduction 2020, 159, 659-668. [CrossRef]

189. Lacroix, M.; El Messaoudi, S.; Rodier, G.; Le Cam, A.; Sardet, C.; Fabbrizio, E. The Histone-Binding Protein COPR5 Is Required for Nuclear Functions of the Protein Arginine Methyltransferase PRMT5. EMBO Rep. 2008, 9, 452-458. [CrossRef]

190. Paul, C.; Delpech, H.; Haouzi, D.; Hamamah, S.; Sardet, C.; Fabbrizio, E. Coprs Inactivation Leads to a Derepression of LINE1 Transposons in Spermatocytes. FEBS Open Bio 2019, 9, 159-168. [CrossRef]

191. Vourekas, A.; Zheng, Q.; Alexiou, P.; Maragkakis, M.; Kirino, Y.; Gregory, B.D.; Mourelatos, Z. Mili and Miwi Target RNA Repertoire Reveals PiRNA Biogenesis and Function of Miwi in Spermiogenesis. Nat. Struct. Mol. Biol. 2012, 19, 773-781. [CrossRef]

192. De Fazio, S.; Bartonicek, N.; Di Giacomo, M.; Abreu-Goodger, C.; Sankar, A.; Funaya, C.; Antony, C.; Moreira, P.N.; Enright, A.J.; O'Carroll, D. The Endonuclease Activity of Mili Fuels PiRNA Amplification That Silences LINE1 Elements. Nature 2011, 480, 259-263. [CrossRef]

193. Zheng, K.; Xiol, J.; Reuter, M.; Eckardt, S.; Leu, N.A.; McLaughlin, K.J.; Stark, A.; Sachidanandam, R.; Pillai, R.S.; Wang, P.J. Mouse MOV10L1 Associates with Piwi Proteins and Is an Essential Component of the Piwi-Interacting RNA (PiRNA) Pathway. Proc. Natl. Acad. Sci. USA 2010, 107, 11841-11846. [CrossRef] [PubMed]

194. Reuter, M.; Chuma, S.; Tanaka, T.; Franz, T.; Stark, A.; Pillai, R.S. Loss of the Mili-Interacting Tudor Domain-Containing Protein-1 Activates Transposons and Alters the Mili-Associated Small RNA Profile. Nat. Struct. Mol. Biol. 2009, 16, 639-646. [CrossRef] [PubMed]

195. Saxe, J.P.; Chen, M.; Zhao, H.; Lin, H. Tdrkh Is Essential for Spermatogenesis and Participates in Primary PiRNA Biogenesis in the Germline. EMBO J. 2013, 32, 1869-1885. [CrossRef]

196. Tan, K.; Kim, M.E.; Song, H.-W.; Skarbrevik, D.; Babajanian, E.; Bedrosian, T.A.; Gage, F.H.; Wilkinson, M.F. The Rhox Gene Cluster Suppresses Germline LINE1 Transposition. Proc. Natl. Acad. Sci. USA 2021, 118, e2024785118. [CrossRef] [PubMed]

197. Ungewitter, E.K.; Rotgers, E.; Kang, H.S.; Lichti-Kaiser, K.; Li, L.; Grimm, S.A.; Jetten, A.M.; Yao, H.H.-C. Loss of Glis3 Causes Dysregulation of Retrotransposon Silencing and Germ Cell Demise in Fetal Mouse Testis. Sci. Rep. 2018, 8, 9662. [CrossRef] [PubMed]

198. Kuramochi-Miyagawa, S.; Watanabe, T.; Gotoh, K.; Takamatsu, K.; Chuma, S.; Kojima-Kita, K.; Shiromoto, Y.; Asada, N.; Toyoda, A.; Fujiyama, A.; et al. MVH in PiRNA Processing and Gene Silencing of Retrotransposons. Genes Dev. 2010, $24,887-892$. [CrossRef] [PubMed]

199. Pandey, R.R.; Tokuzawa, Y.; Yang, Z.; Hayashi, E.; Ichisaka, T.; Kajita, S.; Asano, Y.; Kunieda, T.; Sachidanandam, R.; Chuma, S.; et al. Tudor Domain Containing 12 (TDRD12) Is Essential for Secondary PIWI Interacting RNA Biogenesis in Mice. Proc. Natl. Acad. Sci. USA 2013, 110, 16492-16497. [CrossRef]

200. Xiol, J.; Cora, E.; Koglgruber, R.; Chuma, S.; Subramanian, S.; Hosokawa, M.; Reuter, M.; Yang, Z.; Berninger, P.; Palencia, A.; et al. A Role for Fkbp6 and the Chaperone Machinery in PiRNA Amplification and Transposon Silencing. Mol. Cell 2012, 47, 970-979. [CrossRef]

201. Yoshimura, T.; Watanabe, T.; Kuramochi-Miyagawa, S.; Takemoto, N.; Shiromoto, Y.; Kudo, A.; Kanai-Azuma, M.; Tashiro, F.; Miyazaki, S.; Katanaya, A.; et al. Mouse GTSF1 Is an Essential Factor for Secondary PiRNA Biogenesis. EMBO Rep. 2018, 19, e42054. [CrossRef]

202. Pandey, R.R.; Homolka, D.; Olotu, O.; Sachidanandam, R.; Kotaja, N.; Pillai, R.S. Exonuclease Domain-Containing 1 Enhances MIWI2 PiRNA Biogenesis via Its Interaction with TDRD12. Cell Rep. 2018, 24, 3423-3432.e4. [CrossRef] 
203. Yang, Z.; Chen, K.-M.; Pandey, R.R.; Homolka, D.; Reuter, M.; Janeiro, B.K.R.; Sachidanandam, R.; Fauvarque, M.-O.; McCarthy, A.A.; Pillai, R.S. PIWI Slicing and EXD1 Drive Biogenesis of Nuclear PiRNAs from Cytosolic Targets of the Mouse PiRNA Pathway. Mol. Cell 2016, 61, 138-152. [CrossRef] [PubMed]

204. Yang, F.; Lan, Y.; Pandey, R.R.; Homolka, D.; Berger, S.L.; Pillai, R.S.; Bartolomei, M.S.; Wang, P.J. TEX15 Associates with MILI and Silences Transposable Elements in Male Germ Cells. Genes Dev. 2020, 34, 745-750. [CrossRef] [PubMed]

205. Pastor, W.A.; Stroud, H.; Nee, K.; Liu, W.; Pezic, D.; Manakov, S.; Lee, S.A.; Moissiard, G.; Zamudio, N.; Bourc'his, D.; et al. MORC1 Represses Transposable Elements in the Mouse Male Germline. Nat. Commun. 2014, 5, 5795. [CrossRef] [PubMed]

206. Di Giacomo, M.; Comazzetto, S.; Sampath, S.C.; Sampath, S.C.; O'Carroll, D. G9a Co-Suppresses LINE1 Elements in Spermatogonia. Epigenetics Chromatin 2014, 7, 24. [CrossRef] [PubMed]

207. Ozata, D.M.; Gainetdinov, I.; Zoch, A.; O'Carroll, D.; Zamore, P.D. PIWI-Interacting RNAs: Small RNAs with Big Functions. Nat. Rev. Genet. 2019, 20, 89-108. [CrossRef] [PubMed]

208. O'Carroll, D.; Scherthan, H.; Peters, A.H.; Opravil, S.; Haynes, A.R.; Laible, G.; Rea, S.; Schmid, M.; Lebersorger, A.; Jerratsch, M.; et al. Isolation and Characterization of Suv39h2, a Second Histone H3 Methyltransferase Gene That Displays Testis-Specific Expression. Mol. Cell. Biol. 2000, 20, 9423-9433. [CrossRef] [PubMed]

209. Mahadevan, I.A.; Kumar, S.; Rao, M.R.S. Linker Histone Variant H1t Is Closely Associated with Repressed Repeat-Element Chromatin Domains in Pachytene Spermatocytes. Epigenetics Chromatin 2020, 13, 9. [CrossRef]

210. Mishra, L.N.; Shalini, V.; Gupta, N.; Ghosh, K.; Suthar, N.; Bhaduri, U.; Rao, M.R.S. Spermatid-Specific Linker Histone HILS1 Is a Poor Condenser of DNA and Chromatin and Preferentially Associates with LINE-1 Elements. Epigenetics Chromatin 2018, 11, 43. [CrossRef]

211. Dong, J.; Wang, X.; Cao, C.; Wen, Y.; Sakashita, A.; Chen, S.; Zhang, J.; Zhang, Y.; Zhou, L.; Luo, M.; et al. UHRF1 Suppresses Retrotransposons and Cooperates with PRMT5 and PIWI Proteins in Male Germ Cells. Nat. Commun. 2019, 10, 4705. [CrossRef]

212. Bostick, M.; Kim, J.K.; Estève, P.-O.; Clark, A.; Pradhan, S.; Jacobsen, S.E. UHRF1 Plays a Role in Maintaining DNA Methylation in Mammalian Cells. Science 2007, 317, 1760-1764. [CrossRef]

213. Zhao, Q.; Zhang, J.; Chen, R.; Wang, L.; Li, B.; Cheng, H.; Duan, X.; Zhu, H.; Wei, W.; Li, J.; et al. Dissecting the Precise Role of H3K9 Methylation in Crosstalk with DNA Maintenance Methylation in Mammals. Nat. Commun. 2016, 7, 12464. [CrossRef]

214. Sheng, Y.; Wang, H.; Liu, D.; Zhang, C.; Deng, Y.; Yang, F.; Zhang, T.; Zhang, C. Methylation of Tumor Suppressor Gene CDH13 and SHP1 Promoters and Their Epigenetic Regulation by the UHRF1/PRMT5 Complex in Endometrial Carcinoma. Gynecol. Oncol. 2016, 140, 145-151. [CrossRef]

215. Li, X.; Zhang, J.; Jia, R.; Cheng, V.; Xu, X.; Qiao, W.; Guo, F.; Liang, C.; Cen, S. The MOV10 Helicase Inhibits LINE-1 Mobility. J. Biol. Chem. 2013, 288, 21148-21160. [CrossRef]

216. Zhang, Y.; Guo, R.; Cui, Y.; Zhu, Z.; Zhang, Y.; Wu, H.; Zheng, B.; Yue, Q.; Bai, S.; Zeng, W.; et al. An Essential Role for PNLDC1 in PiRNA 3' End Trimming and Male Fertility in Mice. Cell Res. 2017, 27, 1392-1396. [CrossRef]

217. Ding, D.; Liu, J.; Dong, K.; Midic, U.; Hess, R.A.; Xie, H.; Demireva, E.Y.; Chen, C. PNLDC1 Is Essential for PiRNA $3^{\prime}$ End Trimming and Transposon Silencing during Spermatogenesis in Mice. Nat. Commun. 2017, 8, 819. [CrossRef]

218. Ding, D.; Liu, J.; Dong, K.; Melnick, A.F.; Latham, K.E.; Chen, C. Mitochondrial Membrane-Based Initial Separation of MIWI and MILI Functions during Pachytene PiRNA Biogenesis. Nucleic Acids Res. 2019, 47, 2594-2608. [CrossRef] [PubMed]

219. Wheldon, L.M.; Abakir, A.; Ferjentsik, Z.; Dudnakova, T.; Strohbuecker, S.; Christie, D.; Dai, N.; Guan, S.; Foster, J.M.; Corrêa, I.R.; et al. Transient Accumulation of 5-Carboxylcytosine Indicates Involvement of Active Demethylation in Lineage Specification of Neural Stem Cells. Cell Rep. 2014, 7, 1353-1361. [CrossRef] [PubMed]

220. Blythe, M.J.; Kocer, A.; Rubio-Roldan, A.; Giles, T.; Abakir, A.; Ialy-Radio, C.; Wheldon, L.M.; Bereshchenko, O.; Bruscoli, S.; Kondrashov, A.; et al. LINE-1 Transcription in Round Spermatids Is Associated with Accretion of 5-Carboxylcytosine in Their Open Reading Frames. Commun. Biol. 2021, 4, 691. [CrossRef] [PubMed]

221. Kuramochi-Miyagawa, S.; Kimura, T.; Ijiri, T.W.; Isobe, T.; Asada, N.; Fujita, Y.; Ikawa, M.; Iwai, N.; Okabe, M.; Deng, W.; et al. Mili, a Mammalian Member of Piwi Family Gene, Is Essential for Spermatogenesis. Development 2004, 131, 839-849. [CrossRef]

222. Deng, W.; Lin, H. Miwi, a Murine Homolog of Piwi, Encodes a Cytoplasmic Protein Essential for Spermatogenesis. Dev. Cell 2002, 2, 819-830. [CrossRef]

223. Carmell, M.A.; Girard, A.; van de Kant, H.J.G.; Bourc'his, D.; Bestor, T.H.; de Rooij, D.G.; Hannon, G.J. MIWI2 Is Essential for Spermatogenesis and Repression of Transposons in the Mouse Male Germline. Dev. Cell 2007, 12, 503-514. [CrossRef] [PubMed]

224. Stein, P.; Rozhkov, N.V.; Li, F.; Cárdenas, F.L.; Davydenko, O.; Davydenk, O.; Vandivier, L.E.; Gregory, B.D.; Hannon, G.J.; Schultz, R.M. Essential Role for Endogenous SiRNAs during Meiosis in Mouse Oocytes. PLoS Genet. 2015, 11, e1005013. [CrossRef]

225. Tam, O.H.; Aravin, A.A.; Stein, P.; Girard, A.; Murchison, E.P.; Cheloufi, S.; Hodges, E.; Anger, M.; Sachidanandam, R.; Schultz, R.M.; et al. Pseudogene-Derived Small Interfering RNAs Regulate Gene Expression in Mouse Oocytes. Nature 2008, 453, 534-538. [CrossRef] [PubMed]

226. Taborska, E.; Pasulka, J.; Malik, R.; Horvat, F.; Jenickova, I.; Jelić Matošević, Z.; Svoboda, P. Restricted and Non-Essential Redundancy of RNAi and PiRNA Pathways in Mouse Oocytes. PLoS Genet. 2019, 15, e1008261. [CrossRef] [PubMed]

227. Su, Y.-Q.; Sun, F.; Handel, M.A.; Schimenti, J.C.; Eppig, J.J. Meiosis Arrest Female 1 (MARF1) Has Nuage-like Function in Mammalian Oocytes. Proc. Natl. Acad. Sci. USA 2012, 109, 18653-18660. [CrossRef] 
228. Ollinger, R.; Childs, A.J.; Burgess, H.M.; Speed, R.M.; Lundegaard, P.R.; Reynolds, N.; Gray, N.K.; Cooke, H.J.; Adams, I.R. Deletion of the Pluripotency-Associated Tex19.1 Gene Causes Activation of Endogenous Retroviruses and Defective Spermatogenesis in Mice. PLoS Genet. 2008, 4, e1000199. [CrossRef]

229. Reichmann, J.; Reddington, J.P.; Best, D.; Read, D.; Ollinger, R.; Meehan, R.R.; Adams, I.R. The Genome-Defence Gene Tex19.1 Suppresses LINE-1 Retrotransposons in the Placenta and Prevents Intra-Uterine Growth Retardation in Mice. Hum. Mol. Genet. 2013, 22, 1791-1806. [CrossRef]

230. Tarabay, Y.; Achour, M.; Teletin, M.; Ye, T.; Teissandier, A.; Mark, M.; Bourc'his, D.; Viville, S. Tex19 Paralogs Are New Members of the PiRNA Pathway Controlling Retrotransposon Suppression. J. Cell Sci. 2017, 130, 1463-1474. [CrossRef]

231. MacLennan, M.; García-Cañadas, M.; Reichmann, J.; Khazina, E.; Wagner, G.; Playfoot, C.J.; Salvador-Palomeque, C.; Mann, A.R.; Peressini, P.; Sanchez, L.; et al. Mobilization of LINE-1 Retrotransposons Is Restricted by Tex19.1 in Mouse Embryonic Stem Cells. eLife 2017, 6, e26152. [CrossRef]

232. Muñoz-López, M.; Vilar, R.; Philippe, C.; Rahbari, R.; Richardson, S.R.; Andres-Anton, M.; Widmann, T.; Cano, D.; Cortés, J.L.; Rubio-Roldán, A.; et al. LINE-1 Retrotransposition Impacts the Genome of Human Pre-Implantation Embryos and Extraembryonic Tissues. bioRxiv 2019. [CrossRef]

233. He, Z.; Li, J.; Hwa, Y.L.; Brost, B.; Fang, Q.; Jiang, S.-W. Transition of LINE-1 DNA Methylation Status and Altered Expression in First and Third Trimester Placentas. PLoS ONE 2014, 9, e96994. [CrossRef] [PubMed]

234. Evrony, G.D.; Cai, X.; Lee, E.; Hills, L.B.; Elhosary, P.C.; Lehmann, H.S.; Parker, J.J.; Atabay, K.D.; Gilmore, E.C.; Poduri, A.; et al. Single-Neuron Sequencing Analysis of L1 Retrotransposition and Somatic Mutation in the Human Brain. Cell 2012, 151, 483-496. [CrossRef] [PubMed]

235. Evrony, G.D.; Lee, E.; Mehta, B.K.; Benjamini, Y.; Johnson, R.M.; Cai, X.; Yang, L.; Haseley, P.; Lehmann, H.S.; Park, P.J.; et al. Cell Lineage Analysis in Human Brain Using Endogenous Retroelements. Neuron 2015, 85, 49-59. [CrossRef]

236. Upton, K.R.; Gerhardt, D.J.; Jesuadian, J.S.; Richardson, S.R.; Sánchez-Luque, F.J.; Bodea, G.O.; Ewing, A.D.; Salvador-Palomeque, C.; van der Knaap, M.S.; Brennan, P.M.; et al. Ubiquitous L1 Mosaicism in Hippocampal Neurons. Cell 2015, 161, 228-239. [CrossRef] [PubMed]

237. Breton-Larrivée, M.; Elder, E.; McGraw, S. DNA Methylation, Environmental Exposures and Early Embryo Development. Anim. Reprod. 2019, 16, 465-474. [CrossRef]

238. Valencia, A.M.; Kadoch, C. Chromatin Regulatory Mechanisms and Therapeutic Opportunities in Cancer. Nat. Cell Biol. 2019, 21, 152-161. [CrossRef] [PubMed]

239. Sen, G.L.; Reuter, J.A.; Webster, D.E.; Zhu, L.; Khavari, P.A. DNMT1 Maintains Progenitor Function in Self-Renewing Somatic Tissue. Nature 2010, 463, 563-567. [CrossRef] [PubMed]

240. Jönsson, M.E.; Ludvik Brattås, P.; Gustafsson, C.; Petri, R.; Yudovich, D.; Pircs, K.; Verschuere, S.; Madsen, S.; Hansson, J.; Larsson, J.; et al. Activation of Neuronal Genes via LINE-1 Elements upon Global DNA Demethylation in Human Neural Progenitors. Nat. Commun. 2019, 10, 3182. [CrossRef] [PubMed]

241. Muotri, A.R.; Marchetto, M.C.N.; Coufal, N.G.; Oefner, R.; Yeo, G.; Nakashima, K.; Gage, F.H. L1 Retrotransposition in Neurons Is Modulated by MeCP2. Nature 2010, 468, 443-446. [CrossRef] [PubMed]

242. Yu, F.; Zingler, N.; Schumann, G.; Strätling, W.H. Methyl-CpG-Binding Protein 2 Represses LINE-1 Expression and Retrotransposition but Not Alu Transcription. Nucleic Acids Res. 2001, 29, 4493-4501. [CrossRef] [PubMed]

243. Becker, K.G.; Swergold, G.D.; Ozato, K.; Thayer, R.E. Binding of the Ubiquitous Nuclear Transcription Factor YY1 to a Cis Regulatory Sequence in the Human LINE-1 Transposable Element. Hum. Mol. Genet. 1993, 2, 1697-1702. [CrossRef] [PubMed]

244. Kapushesky, M.; Emam, I.; Holloway, E.; Kurnosov, P.; Zorin, A.; Malone, J.; Rustici, G.; Williams, E.; Parkinson, H.; Brazma, A. Gene Expression Atlas at the European Bioinformatics Institute. Nucleic Acids Res. 2010, 38, D690-D698. [CrossRef]

245. Wolf, D.; Goff, S.P. TRIM28 Mediates Primer Binding Site-Targeted Silencing of Murine Leukemia Virus in Embryonic Cells. Cell 2007, 131, 46-57. [CrossRef] [PubMed]

246. Wolf, D.; Goff, S.P. Embryonic Stem Cells Use ZFP809 to Silence Retroviral DNAs. Nature 2009, 458, 1201-1204. [CrossRef]

247. Schultz, D.C.; Ayyanathan, K.; Negorev, D.; Maul, G.G.; Rauscher, F.J. SETDB1: A Novel KAP-1-Associated Histone H3, Lysine 9-Specific Methyltransferase That Contributes to HP1-Mediated Silencing of Euchromatic Genes by KRAB Zinc-Finger Proteins. Genes Dev. 2002, 16, 919-932. [CrossRef]

248. Ivanov, A.V.; Peng, H.; Yurchenko, V.; Yap, K.L.; Negorev, D.G.; Schultz, D.C.; Psulkowski, E.; Fredericks, W.J.; White, D.E.; Maul, G.G.; et al. PHD Domain-Mediated E3 Ligase Activity Directs Intramolecular Sumoylation of an Adjacent Bromodomain Required for Gene Silencing. Mol. Cell 2007, 28, 823-837. [CrossRef]

249. Rowe, H.M.; Jakobsson, J.; Mesnard, D.; Rougemont, J.; Reynard, S.; Aktas, T.; Maillard, P.V.; Layard-Liesching, H.; Verp, S.; Marquis, J.; et al. KAP1 Controls Endogenous Retroviruses in Embryonic Stem Cells. Nature 2010, 463, 237-240. [CrossRef]

250. Tchasovnikarova, I.A.; Timms, R.T.; Matheson, N.J.; Wals, K.; Antrobus, R.; Göttgens, B.; Dougan, G.; Dawson, M.A.; Lehner, P.J. GENE SILENCING. Epigenetic Silencing by the HUSH Complex Mediates Position-Effect Variegation in Human Cells. Science 2015, 348, 1481-1485. [CrossRef]

251. Tchasovnikarova, I.A.; Timms, R.T.; Douse, C.H.; Roberts, R.C.; Dougan, G.; Kingston, R.E.; Modis, Y.; Lehner, P.J. Hyperactivation of HUSH Complex Function by Charcot-Marie-Tooth Disease Mutation in MORC2. Nat. Genet. 2017, 49, 1035-1044. [CrossRef] 
252. Ren, W.; Fan, H.; Grimm, S.A.; Guo, Y.; Kim, J.J.; Yin, J.; Li, L.; Petell, C.J.; Tan, X.-F.; Zhang, Z.-M.; et al. Direct Readout of Heterochromatic H3K9me3 Regulates DNMT1-Mediated Maintenance DNA Methylation. Proc. Natl. Acad. Sci. USA 2020, 117, 18439-18447. [CrossRef]

253. Ren, W.; Fan, H.; Grimm, S.A.; Kim, J.J.; Li, L.; Guo, Y.; Petell, C.J.; Tan, X.-F.; Zhang, Z.-M.; Coan, J.P.; et al. DNMT1 Reads Heterochromatic H4K20me3 to Reinforce LINE-1 DNA Methylation. Nat. Commun. 2021, 12, 2490. [CrossRef]

254. Lee, E.J.; Banerjee, S.; Zhou, H.; Jammalamadaka, A.; Arcila, M.; Manjunath, B.S.; Kosik, K.S. Identification of PiRNAs in the Central Nervous System. RNA 2011, 17, 1090-1099. [CrossRef]

255. Nandi, S.; Chandramohan, D.; Fioriti, L.; Melnick, A.M.; Hébert, J.M.; Mason, C.E.; Rajasethupathy, P.; Kandel, E.R. Roles for Small Noncoding RNAs in Silencing of Retrotransposons in the Mammalian Brain. Proc. Natl. Acad. Sci. USA 2016, 113, 12697-12702. [CrossRef]

256. Leighton, L.J.; Wei, W.; Marshall, P.R.; Ratnu, V.S.; Li, X.; Zajaczkowski, E.L.; Spadaro, P.A.; Khandelwal, N.; Kumar, A.; Bredy, T.W. Disrupting the Hippocampal Piwi Pathway Enhances Contextual Fear Memory in Mice. Neurobiol. Learn Mem. 2019, 161, 202-209. [CrossRef]

257. Burns, K.H. Transposable Elements in Cancer. Nat. Rev. Cancer 2017, 17, 415-424. [CrossRef]

258. Rodic, N. LINE-1 Activity and Regulation in Cancer. Front. Biosci. (Landmark Ed.) 2018, 23, 1680-1686. [CrossRef] [PubMed]

259. Saleh, A.; Macia, A.; Muotri, A.R. Transposable Elements, Inflammation, and Neurological Disease. Front. Neurol. 2019, 10, 894. [CrossRef] [PubMed]

260. Misiak, B.; Ricceri, L.; Sąsiadek, M.M. Transposable Elements and Their Epigenetic Regulation in Mental Disorders: Current Evidence in the Field. Front. Genet. 2019, 10, 580. [CrossRef] [PubMed]

261. Lapp, H.E.; Hunter, R.G. Early Life Exposures, Neurodevelopmental Disorders, and Transposable Elements. Neurobiol. Stress 2019, 11, 100174. [CrossRef]

262. Rohrback, S.; Siddoway, B.; Liu, C.S.; Chun, J. Genomic Mosaicism in the Developing and Adult Brain. Dev. Neurobiol. 2018, 78, 1026-1048. [CrossRef] [PubMed]

263. Suarez, N.A.; Macia, A.; Muotri, A.R. LINE-1 Retrotransposons in Healthy and Diseased Human Brain. Dev. Neurobiol. 2018, 78, 434-455. [CrossRef]

264. Basil, P.; Li, Q.; Sham, P.-C.; McAlonan, G.M. LINE1 and Mecp2 Methylation of the Adult Striatum and Prefrontal Cortex Exposed to Prenatal Immune Activation. Data Brief 2019, 25, 104003. [CrossRef] [PubMed]

265. Caliri, A.W.; Caceres, A.; Tommasi, S.; Besaratinia, A. Hypomethylation of LINE-1 Repeat Elements and Global Loss of DNA Hydroxymethylation in Vapers and Smokers. Epigenetics 2020, 15, 816-829. [CrossRef] [PubMed]

266. Maugeri, A.; Barchitta, M.; Fallico, M.; Castellino, N.; Reibaldi, M.; Agodi, A. Characterization of SIRT1/DNMTs Functions and LINE-1 Methylation in Patients with Age-Related Macular Degeneration. J. Clin. Med. 2019, 8, 159. [CrossRef] [PubMed]

267. Van Meter, M.; Kashyap, M.; Rezazadeh, S.; Geneva, A.J.; Morello, T.D.; Seluanov, A.; Gorbunova, V. SIRT6 Represses LINE1 Retrotransposons by Ribosylating KAP1 but This Repression Fails with Stress and Age. Nat. Commun. 2014, 5, 5011. [CrossRef]

268. Vazquez, B.N.; Thackray, J.K.; Simonet, N.G.; Chahar, S.; Kane-Goldsmith, N.; Newkirk, S.J.; Lee, S.; Xing, J.; Verzi, M.P.; An, W.; et al. SIRT7 Mediates L1 Elements Transcriptional Repression and Their Association with the Nuclear Lamina. Nucleic Acids Res. 2019, 47, 7870-7885. [CrossRef]

269. Montoya-Durango, D.E.; Ramos, K.A.; Bojang, P.; Ruiz, L.; Ramos, I.N.; Ramos, K.S. LINE-1 Silencing by Retinoblastoma Proteins Is Effected through the Nucleosomal and Remodeling Deacetylase Multiprotein Complex. BMC Cancer 2016, 16, 38. [CrossRef]

270. Sahnane, N.; Ottini, G.; Turri-Zanoni, M.; Furlan, D.; Battaglia, P.; Karligkiotis, A.; Albeni, C.; Cerutti, R.; Mura, E.; Chiaravalli, A.M.; et al. Comprehensive Analysis of HPV Infection, EGFR Exon 20 Mutations and LINE1 Hypomethylation as Risk Factors for Malignant Transformation of Sinonasal-Inverted Papilloma to Squamous Cell Carcinoma. Int. J. Cancer 2019, 144, 1313-1320. [CrossRef]

271. Tahara, S.; Tahara, T.; Horiguchi, N.; Okubo, M.; Terada, T.; Yoshida, D.; Funasaka, K.; Nakagawa, Y.; Shibata, T.; Tsukamoto, T.; et al. Lower LINE-1 Methylation Is Associated with Promoter Hypermethylation and Distinct Molecular Features in Gastric Cancer. Epigenomics 2019, 11, 1651-1659. [CrossRef]

272. Ponomarev, I.; Wang, S.; Zhang, L.; Harris, R.A.; Mayfield, R.D. Gene Coexpression Networks in Human Brain Identify Epigenetic Modifications in Alcohol Dependence. J. Neurosci. 2012, 32, 1884-1897. [CrossRef]

273. Okudaira, N.; Ishizaka, Y.; Nishio, H. Retrotransposition of Long Interspersed Element 1 Induced by Methamphetamine or Cocaine. J. Biol. Chem. 2014, 289, 25476-25485. [CrossRef]

274. Moszczynska, A.; Flack, A.; Qiu, P.; Muotri, A.R.; Killinger, B.A. Neurotoxic Methamphetamine Doses Increase LINE-1 Expression in the Neurogenic Zones of the Adult Rat Brain. Sci. Rep. 2015, 5, 14356. [CrossRef]

275. Kale, S.P.; Moore, L.; Deininger, P.L.; Roy-Engel, A.M. Heavy Metals Stimulate Human LINE-1 Retrotransposition. Int. J. Environ. Res. Public Health 2005, 2, 14-23. [CrossRef]

276. Kalayasiri, R.; Kraijak, K.; Maes, M.; Mutirangura, A. Methamphetamine (MA) Use Induces Specific Changes in LINE-1 Partial Methylation Patterns, Which Are Associated with MA-Induced Paranoia: A Multivariate and Neuronal Network Study. Mol. Neurobiol. 2019, 56, 4258-4272. [CrossRef]

277. Del Re, B.; Giorgi, G. Long INterspersed Element-1 Mobility as a Sensor of Environmental Stresses. Environ. Mol. Mutagen. 2020, 61, 465-493. [CrossRef] [PubMed] 
278. Moore, L.D.; Le, T.; Fan, G. DNA Methylation and Its Basic Function. Neuropsychopharmacology 2013, 38, 23-38. [CrossRef] [PubMed]

279. Ruiz-Hernandez, A.; Kuo, C.-C.; Rentero-Garrido, P.; Tang, W.-Y.; Redon, J.; Ordovas, J.M.; Navas-Acien, A.; Tellez-Plaza, M. Environmental Chemicals and DNA Methylation in Adults: A Systematic Review of the Epidemiologic Evidence. Clin. Epigenetics 2015, 7, 55. [CrossRef] [PubMed]

280. Cardelli, M. The Epigenetic Alterations of Endogenous Retroelements in Aging. Mech. Ageing Dev. 2018, 174, 30-46. [CrossRef] [PubMed]

281. Salameh, Y.; Bejaoui, Y.; El Hajj, N. DNA Methylation Biomarkers in Aging and Age-Related Diseases. Front. Genet. 2020, 11, 171. [CrossRef]

282. Basil, P.; Li, Q.; Dempster, E.L.; Mill, J.; Sham, P.-C.; Wong, C.C.Y.; McAlonan, G.M. Prenatal Maternal Immune Activation Causes Epigenetic Differences in Adolescent Mouse Brain. Transl. Psychiatry 2014, 4, e434. [CrossRef] [PubMed]

283. Basil, P.; Li, Q.; Gui, H.; Hui, T.C.K.; Ling, V.H.M.; Wong, C.C.Y.; Mill, J.; McAlonan, G.M.; Sham, P.-C. Prenatal Immune Activation Alters the Adult Neural Epigenome but Can Be Partly Stabilised by a N-3 Polyunsaturated Fatty Acid Diet. Transl. Psychiatry 2018, 8, 125. [CrossRef] [PubMed]

284. Conway, F.; Brown, A.S. Maternal Immune Activation and Related Factors in the Risk of Offspring Psychiatric Disorders. Front. Psychiatry 2019, 10, 430. [CrossRef] [PubMed]

285. Amodeo, D.A.; Lai, C.-Y.; Hassan, O.; Mukamel, E.A.; Behrens, M.M.; Powell, S.B. Maternal Immune Activation Impairs Cognitive Flexibility and Alters Transcription in Frontal Cortex. Neurobiol. Dis. 2019, 125, 211-218. [CrossRef] [PubMed]

286. Lee, S.-H.; Lee, J.-H.; Lee, H.-Y.; Min, K.-J. Sirtuin Signaling in Cellular Senescence and Aging. BMB Rep. 2019, 52, 24-34. [CrossRef] [PubMed]

287. Lagunas-Rangel, F.A. Current Role of Mammalian Sirtuins in DNA Repair. DNA Repair. 2019, 80, 85-92. [CrossRef]

288. Mendes, K.L.; de Farias Lelis, D.; Santos, S.H.S. Nuclear Sirtuins and Inflammatory Signaling Pathways. Cytokine Growth Factor Rev. 2017, 38, 98-105. [CrossRef]

289. Zhou, S.; Tang, X.; Chen, H.-Z. Sirtuins and Insulin Resistance. Front. Endocrinol. 2018, 9, 748. [CrossRef]

290. De Céu Teixeira, M.; Sanchez-Lopez, E.; Espina, M.; Garcia, M.L.; Durazzo, A.; Lucarini, M.; Novellino, E.; Souto, S.B.; Santini, A.; Souto, E.B. Sirtuins and SIRT6 in Carcinogenesis and in Diet. Int. J. Mol. Sci. 2019, 20, 4945. [CrossRef]

291. De Cecco, M.; Ito, T.; Petrashen, A.P.; Elias, A.E.; Skvir, N.J.; Criscione, S.W.; Caligiana, A.; Brocculi, G.; Adney, E.M.; Boeke, J.D.; et al. L1 Drives IFN in Senescent Cells and Promotes Age-Associated Inflammation. Nature 2019, 566, 73-78. [CrossRef] [PubMed]

292. Simon, M.; Van Meter, M.; Ablaeva, J.; Ke, Z.; Gonzalez, R.S.; Taguchi, T.; De Cecco, M.; Leonova, K.I.; Kogan, V.; Helfand, S.L.; et al. LINE1 Derepression in Aged Wild-Type and SIRT6-Deficient Mice Drives Inflammation. Cell Metab. 2019, 29, 871-885.e5. [CrossRef] [PubMed]

293. Kumari, P.; Popescu, D.; Yue, S.; Bober, E.; Ianni, A.; Braun, T. Sirt7 Inhibits Sirt1-Mediated Activation of Suv39h1. Cell Cycle 2018, 17, 1403-1412. [CrossRef] [PubMed]

294. Min, B.; Jeon, K.; Park, J.S.; Kang, Y.-K. Demethylation and Derepression of Genomic Retroelements in the Skeletal Muscles of Aged Mice. Aging Cell 2019, 18, e13042. [CrossRef]

295. Fujita, N.; Jaye, D.L.; Geigerman, C.; Akyildiz, A.; Mooney, M.R.; Boss, J.M.; Wade, P.A. MTA3 and the Mi-2/NuRD Complex Regulate Cell Fate during B Lymphocyte Differentiation. Cell 2004, 119, 75-86. [CrossRef]

296. Jiang, C.-L.; Jin, S.-G.; Pfeifer, G.P. MBD3L1 Is a Transcriptional Repressor That Interacts with Methyl-CpG-Binding Protein 2 (MBD2) and Components of the NuRD Complex. J. Biol. Chem. 2004, 279, 52456-52464. [CrossRef]

297. Ramírez, J.; Dege, C.; Kutateladze, T.G.; Hagman, J. MBD2 and Multiple Domains of CHD4 Are Required for Transcriptional Repression by Mi-2/NuRD Complexes. Mol. Cell. Biol. 2012, 32, 5078-5088. [CrossRef]

298. Bojang, P.; Ramos, K.S. Epigenetic Reactivation of LINE-1 Retrotransposon Disrupts NuRD Corepressor Functions and Induces Oncogenic Transformation in Human Bronchial Epithelial Cells. Mol. Oncol. 2018, 12, 1342-1357. [CrossRef] [PubMed]

299. Montoya-Durango, D.E.; Liu, Y.; Teneng, I.; Kalbfleisch, T.; Lacy, M.E.; Steffen, M.C.; Ramos, K.S. Epigenetic Control of Mammalian LINE-1 Retrotransposon by Retinoblastoma Proteins. Mutat. Res. 2009, 665, 20-28. [CrossRef]

300. Ishak, C.A.; Marshall, A.E.; Passos, D.T.; White, C.R.; Kim, S.J.; Cecchini, M.J.; Ferwati, S.; MacDonald, W.A.; Howlett, C.J.; Welch, I.D.; et al. An RB-EZH2 Complex Mediates Silencing of Repetitive DNA Sequences. Mol. Cell 2016, 64, 1074-1087. [CrossRef] [PubMed]

301. Hamdorf, M.; Idica, A.; Zisoulis, D.G.; Gamelin, L.; Martin, C.; Sanders, K.J.; Pedersen, I.M. MiR-128 Represses L1 Retrotransposition by Binding Directly to L1 RNA. Nat. Struct. Mol. Biol. 2015, 22, 824-831. [CrossRef]

302. Idica, A.; Sevrioukov, E.A.; Zisoulis, D.G.; Hamdorf, M.; Daugaard, I.; Kadandale, P.; Pedersen, I.M. MicroRNA MiR-128 Represses LINE-1 (L1) Retrotransposition by down-Regulating the Nuclear Import Factor TNPO1. J. Biol. Chem. 2017, $292,20494-20508$. [CrossRef]

303. Fung, L.; Guzman, H.; Sevrioukov, E.; Idica, A.; Park, E.; Bochnakian, A.; Daugaard, I.; Jury, D.; Mortazavi, A.; Zisoulis, D.G.; et al. MiR-128 Restriction of LINE-1 (L1) Retrotransposition Is Dependent on Targeting HnRNPA1 MRNA. Int. J. Mol. Sci. 2019, 20, 1955. [CrossRef] 
304. Kimura, M.; Kose, S.; Okumura, N.; Imai, K.; Furuta, M.; Sakiyama, N.; Tomii, K.; Horton, P.; Takao, T.; Imamoto, N. Identification of Cargo Proteins Specific for the Nucleocytoplasmic Transport Carrier Transportin by Combination of an in Vitro Transport System and Stable Isotope Labeling by Amino Acids in Cell Culture (SILAC)-Based Quantitative Proteomics. Mol. Cell Proteom. 2013, 12, 145-157. [CrossRef] [PubMed]

305. Twyffels, L.; Gueydan, C.; Kruys, V. Transportin-1 and Transportin-2: Protein Nuclear Import and Beyond. FEBS Lett. 2014, 588, 1857-1868. [CrossRef] [PubMed]

306. Reed, R.; Hurt, E. A Conserved MRNA Export Machinery Coupled to Pre-MRNA Splicing. Cell 2002, 108, 523-531. [CrossRef]

307. Li, P.W.-L.; Li, J.; Timmerman, S.L.; Krushel, L.A.; Martin, S.L. The Dicistronic RNA from the Mouse LINE-1 Retrotransposon Contains an Internal Ribosome Entry Site Upstream of Each ORF: Implications for Retrotransposition. Nucleic Acids Res. 2006, 34, 853-864. [CrossRef] [PubMed]

308. Peddigari, S.; Li, P.W.-L.; Rabe, J.L.; Martin, S.L. HnRNPL and Nucleolin Bind LINE-1 RNA and Function as Host Factors to Modulate Retrotransposition. Nucleic Acids Res. 2013, 41, 575-585. [CrossRef]

309. Denli, A.M.; Tops, B.B.J.; Plasterk, R.H.A.; Ketting, R.F.; Hannon, G.J. Processing of Primary MicroRNAs by the Microprocessor Complex. Nature 2004, 432, 231-235. [CrossRef]

310. Gregory, R.I.; Yan, K.-P.; Amuthan, G.; Chendrimada, T.; Doratotaj, B.; Cooch, N.; Shiekhattar, R. The Microprocessor Complex Mediates the Genesis of MicroRNAs. Nature 2004, 432, 235-240. [CrossRef]

311. Han, J.; Lee, Y.; Yeom, K.-H.; Kim, Y.-K.; Jin, H.; Kim, V.N. The Drosha-DGCR8 Complex in Primary MicroRNA Processing. Genes Dev. 2004, 18, 3016-3027. [CrossRef]

312. Kim, V.N.; Han, J.; Siomi, M.C. Biogenesis of Small RNAs in Animals. Nat. Rev. Mol. Cell. Biol. 2009, 10, 126-139. [CrossRef]

313. Heras, S.R.; Macias, S.; Plass, M.; Fernandez, N.; Cano, D.; Eyras, E.; Garcia-Perez, J.L.; Cáceres, J.F. The Microprocessor Controls the Activity of Mammalian Retrotransposons. Nat. Struct. Mol. Biol. 2013, 20, 1173-1181. [CrossRef]

314. Ikeda, T.; Shimoda, M.; Ebrahimi, D.; VandeBerg, J.L.; Harris, R.S.; Koito, A.; Maeda, K. Opossum APOBEC1 Is a DNA Mutator with Retrovirus and Retroelement Restriction Activity. Sci. Rep. 2017, 7, 46719. [CrossRef]

315. Lahouassa, H.; Daddacha, W.; Hofmann, H.; Ayinde, D.; Logue, E.C.; Dragin, L.; Bloch, N.; Maudet, C.; Bertrand, M.; Gramberg, T.; et al. SAMHD1 Restricts the Replication of Human Immunodeficiency Virus Type 1 by Depleting the Intracellular Pool of Deoxynucleoside Triphosphates. Nat. Immunol. 2012, 13, 223-228. [CrossRef] [PubMed]

316. Zhao, K.; Du, J.; Han, X.; Goodier, J.L.; Li, P.; Zhou, X.; Wei, W.; Evans, S.L.; Li, L.; Zhang, W.; et al. Modulation of LINE-1 and Alu/SVA Retrotransposition by Aicardi-Goutières Syndrome-Related SAMHD1. Cell Rep. 2013, 4, 1108-1115. [CrossRef] [PubMed]

317. Renner, T.M.; Bélanger, K.; Goodwin, L.R.; Campbell, M.; Langlois, M.-A. Characterization of Molecular Attributes That Influence LINE-1 Restriction by All Seven Human APOBEC3 Proteins. Virology 2018, 520, 127-136. [CrossRef] [PubMed]

318. Zhao, K.; Du, J.; Peng, Y.; Li, P.; Wang, S.; Wang, Y.; Hou, J.; Kang, J.; Zheng, W.; Hua, S.; et al. LINE1 Contributes to Autoimmunity through Both RIG-I- and MDA5-Mediated RNA Sensing Pathways. J. Autoimmun. 2018, 90, 105-115. [CrossRef]

319. Tunbak, H.; Enriquez-Gasca, R.; Tie, C.H.C.; Gould, P.A.; Mlcochova, P.; Gupta, R.K.; Fernandes, L.; Holt, J.; van der Veen, A.G.; Giampazolias, E.; et al. The HUSH Complex Is a Gatekeeper of Type I Interferon through Epigenetic Regulation of LINE-1s. Nat. Commun. 2020, 11, 5387. [CrossRef]

320. Rostami, M.R.; Bradic, M. The Derepression of Transposable Elements in Lung Cells Is Associated with the Inflammatory Response and Gene Activation in Idiopathic Pulmonary Fibrosis. Mob. DNA 2021, 12, 14. [CrossRef]

321. Kawano, K.; Doucet, A.J.; Ueno, M.; Kariya, R.; An, W.; Marzetta, F.; Kuroki, M.; Turelli, P.; Sukegawa, S.; Okada, S.; et al. HIV-1 Vpr and P21 Restrict LINE-1 Mobility. Nucleic Acids Res. 2018, 46, 8454-8470. [CrossRef]

322. Schöbel, A.; Nguyen-Dinh, V.; Schumann, G.G.; Herker, E. Hepatitis C Virus Infection Restricts Human LINE-1 Retrotransposition in Hepatoma Cells. PLoS Pathog. 2021, 17, e1009496. [CrossRef]

323. Crow, Y.J.; Chase, D.S.; Lowenstein Schmidt, J.; Szynkiewicz, M.; Forte, G.M.A.; Gornall, H.L.; Oojageer, A.; Anderson, B.; Pizzino, A.; Helman, G.; et al. Characterization of Human Disease Phenotypes Associated with Mutations in TREX1, RNASEH2A, RNASEH2B, RNASEH2C, SAMHD1, ADAR, and IFIH1. Am. J. Med. Genet. A 2015, 167A, 296-312. [CrossRef] [PubMed]

324. Zhang, A.; Dong, B.; Doucet, A.J.; Moldovan, J.B.; Moran, J.V.; Silverman, R.H. RNase L Restricts the Mobility of Engineered Retrotransposons in Cultured Human Cells. Nucleic Acids Res. 2014, 42, 3803-3820. [CrossRef] [PubMed]

325. Malathi, K.; Dong, B.; Gale, M.; Silverman, R.H. Small Self-RNA Generated by RNase L Amplifies Antiviral Innate Immunity. Nature 2007, 448, 816-819. [CrossRef] [PubMed]

326. Reikine, S.; Nguyen, J.B.; Modis, Y. Pattern Recognition and Signaling Mechanisms of RIG-I and MDA5. Front. Immunol. 2014, 5, 342. [CrossRef]

327. Oshiumi, H.; Kouwaki, T.; Seya, T. Accessory Factors of Cytoplasmic Viral RNA Sensors Required for Antiviral Innate Immune Response. Front. Immunol. 2016, 7, 200. [CrossRef]

328. Arjan-Odedra, S.; Swanson, C.M.; Sherer, N.M.; Wolinsky, S.M.; Malim, M.H. Endogenous MOV10 Inhibits the Retrotransposition of Endogenous Retroelements but Not the Replication of Exogenous Retroviruses. Retrovirology 2012, 9, 53. [CrossRef]

329. Choi, J.; Hwang, S.-Y.; Ahn, K. Interplay between RNASEH2 and MOV10 Controls LINE-1 Retrotransposition. Nucleic Acids Res. 2018, 46, 1912-1926. [CrossRef]

330. Goodier, J.L.; Cheung, L.E.; Kazazian, H.H. MOV10 RNA Helicase Is a Potent Inhibitor of Retrotransposition in Cells. PLoS Genet. 2012, 8, e1002941. [CrossRef] 
331. Skariah, G.; Seimetz, J.; Norsworthy, M.; Lannom, M.C.; Kenny, P.J.; Elrakhawy, M.; Forsthoefel, C.; Drnevich, J.; Kalsotra, A.; Ceman, S. Mov10 Suppresses Retroelements and Regulates Neuronal Development and Function in the Developing Brain. BMC Biol. 2017, 15, 54. [CrossRef] [PubMed]

332. Moldovan, J.B.; Moran, J.V. The Zinc-Finger Antiviral Protein ZAP Inhibits LINE and Alu Retrotransposition. PLoS Genet. 2015, 11, e1005121. [CrossRef] [PubMed]

333. Benitez-Guijarro, M.; Lopez-Ruiz, C.; Tarnauskaitè, Ž.; Murina, O.; Mian Mohammad, M.; Williams, T.C.; Fluteau, A.; Sanchez, L.; Vilar-Astasio, R.; Garcia-Canadas, M.; et al. RNase H2, Mutated in Aicardi-Goutières Syndrome, Promotes LINE-1 Retrotransposition. EMBO J. 2018, 37, e98506. [CrossRef]

334. Warkocki, Z.; Krawczyk, P.S.; Adamska, D.; Bijata, K.; Garcia-Perez, J.L.; Dziembowski, A. Uridylation by TUT4/7 Restricts Retrotransposition of Human LINE-1s. Cell 2018, 174, 1537-1548.e29. [CrossRef] [PubMed]

335. Sampath, P.; Mazumder, B.; Seshadri, V.; Gerber, C.A.; Chavatte, L.; Kinter, M.; Ting, S.M.; Dignam, J.D.; Kim, S.; Driscoll, D.M.; et al. Noncanonical Function of Glutamyl-Prolyl-TRNA Synthetase: Gene-Specific Silencing of Translation. Cell 2004, 119, 195-208. [CrossRef] [PubMed]

336. Kapasi, P.; Chaudhuri, S.; Vyas, K.; Baus, D.; Komar, A.A.; Fox, P.L.; Merrick, W.C.; Mazumder, B. L13a Blocks 48S Assembly: Role of a General Initiation Factor in MRNA-Specific Translational Control. Mol. Cell 2007, 25, 113-126. [CrossRef]

337. Ward, J.R.; Vasu, K.; Deutschman, E.; Halawani, D.; Larson, P.A.; Zhang, D.; Willard, B.; Fox, P.L.; Moran, J.V.; Longworth, M.S. Condensin II and GAIT Complexes Cooperate to Restrict LINE-1 Retrotransposition in Epithelial Cells. PLoS Genet. 2017, 13, e1007051. [CrossRef]

338. Mukhopadhyay, R.; Jia, J.; Arif, A.; Ray, P.S.; Fox, P.L. The GAIT System: A Gatekeeper of Inflammatory Gene Expression. Trends Biochem. Sci. 2009, 34, 324-331. [CrossRef]

339. Stetson, D.B. Endogenous Retroelements and Autoimmune Disease. Curr. Opin. Immunol. 2012, 24, 692-697. [CrossRef]

340. Li, P.; Du, J.; Goodier, J.L.; Hou, J.; Kang, J.; Kazazian, H.H.; Zhao, K.; Yu, X.-F. Aicardi-Goutières Syndrome Protein TREX1 Suppresses L1 and Maintains Genome Integrity through Exonuclease-Independent ORF1p Depletion. Nucleic Acids Res. 2017, 45, 4619-4631. [CrossRef]

341. Stetson, D.B.; Ko, J.S.; Heidmann, T.; Medzhitov, R. Trex1 Prevents Cell-Intrinsic Initiation of Autoimmunity. Cell 2008, 134, 587-598. [CrossRef]

342. Chowdhury, D.; Beresford, P.J.; Zhu, P.; Zhang, D.; Sung, J.-S.; Demple, B.; Perrino, F.W.; Lieberman, J. The Exonuclease TREX1 Is in the SET Complex and Acts in Concert with NM23-H1 to Degrade DNA during Granzyme A-Mediated Cell Death. Mol. Cell 2006, 23, 133-142. [CrossRef]

343. Vembar, S.S.; Brodsky, J.L. One Step at a Time: Endoplasmic Reticulum-Associated Degradation. Nat. Rev. Mol. Cell. Biol. 2008, 9 , 944-957. [CrossRef]

344. Deutschmann, J.; Gramberg, T. SAMHD1 ... and Viral Ways around It. Viruses 2021, 13, 395. [CrossRef]

345. Chen, S.; Bonifati, S.; Qin, Z.; St Gelais, C.; Wu, L. SAMHD1 Suppression of Antiviral Immune Responses. Trends Microbiol. 2019, 27, 254-267. [CrossRef]

346. Rice, G.I.; Bond, J.; Asipu, A.; Brunette, R.L.; Manfield, I.W.; Carr, I.M.; Fuller, J.C.; Jackson, R.M.; Lamb, T.; Briggs, T.A.; et al. Mutations Involved in Aicardi-Goutières Syndrome Implicate SAMHD1 as Regulator of the Innate Immune Response. Nat. Genet. 2009, 41, 829-832. [CrossRef] [PubMed]

347. Hu, S.; Li, J.; Xu, F.; Mei, S.; Le Duff, Y.; Yin, L.; Pang, X.; Cen, S.; Jin, Q.; Liang, C.; et al. SAMHD1 Inhibits LINE-1 Retrotransposition by Promoting Stress Granule Formation. PLoS Genet. 2015, 11, e1005367. [CrossRef] [PubMed]

348. White, T.E.; Brandariz-Nuñez, A.; Han, K.; Sawyer, S.L.; Kim, B.; Diaz-Griffero, F. Modulation of LINE-1 Retrotransposition by a Human SAMHD1 Polymorphism. Virol. Rep. 2016, 6, 53-60. [CrossRef] [PubMed]

349. Du, J.; Peng, Y.; Wang, S.; Hou, J.; Wang, Y.; Sun, T.; Zhao, K. Nucleocytoplasmic Shuttling of SAMHD1 Is Important for LINE-1 Suppression. Biochem. Biophys. Res. Commun. 2019, 510, 551-557. [CrossRef]

350. Rose, K.M.; Spada, S.J.; Broeckel, R.; McNally, K.L.; Hirsch, V.M.; Best, S.M.; Bouamr, F. From Capsids to Complexes: Expanding the Role of TRIM $5 \alpha$ in the Restriction of Divergent RNA Viruses and Elements. Viruses 2021, 13, 446. [CrossRef]

351. Ganser-Pornillos, B.K.; Chandrasekaran, V.; Pornillos, O.; Sodroski, J.G.; Sundquist, W.I.; Yeager, M. Hexagonal Assembly of a Restricting TRIM5alpha Protein. Proc. Natl. Acad. Sci. USA 2011, 108, 534-539. [CrossRef] [PubMed]

352. Volkmann, B.; Wittmann, S.; Lagisquet, J.; Deutschmann, J.; Eissmann, K.; Ross, J.J.; Biesinger, B.; Gramberg, T. Human TRIM5 $\alpha$ Senses and Restricts LINE-1 Elements. Proc. Natl. Acad. Sci. USA 2020, 117, 17965-17976. [CrossRef] [PubMed]

353. Goodier, J.L. Restricting Retrotransposons: A Review. Mob. DNA 2016, 7, 16. [CrossRef] [PubMed]

354. Silvas, T.V.; Schiffer, C.A. APOBEC3s: DNA-Editing Human Cytidine Deaminases. Protein Sci. 2019, 28, 1552-1566. [CrossRef] [PubMed]

355. Bogerd, H.P.; Wiegand, H.L.; Hulme, A.E.; Garcia-Perez, J.L.; O’Shea, K.S.; Moran, J.V.; Cullen, B.R. Cellular Inhibitors of Long Interspersed Element 1 and Alu Retrotransposition. Proc. Natl. Acad. Sci. USA 2006, 103, 8780-8785. [CrossRef]

356. Muckenfuss, H.; Hamdorf, M.; Held, U.; Perković, M.; Löwer, J.; Cichutek, K.; Flory, E.; Schumann, G.G.; Münk, C. APOBEC3 Proteins Inhibit Human LINE-1 Retrotransposition. J. Biol. Chem. 2006, 281, 22161-22172. [CrossRef]

357. Stenglein, M.D.; Harris, R.S. APOBEC3B and APOBEC3F Inhibit L1 Retrotransposition by a DNA Deamination-Independent Mechanism. J. Biol. Chem. 2006, 281, 16837-16841. [CrossRef] 
358. Kinomoto, M.; Kanno, T.; Shimura, M.; Ishizaka, Y.; Kojima, A.; Kurata, T.; Sata, T.; Tokunaga, K. All APOBEC3 Family Proteins Differentially Inhibit LINE-1 Retrotransposition. Nucleic Acids Res. 2007, 35, 2955-2964. [CrossRef]

359. Niewiadomska, A.M.; Tian, C.; Tan, L.; Wang, T.; Sarkis, P.T.N.; Yu, X.-F. Differential Inhibition of Long Interspersed Element 1 by APOBEC3 Does Not Correlate with High-Molecular-Mass-Complex Formation or P-Body Association. J. Virol. 2007, 81, 9577-9583. [CrossRef]

360. Feng, Y.; Goubran, M.H.; Follack, T.B.; Chelico, L. Deamination-Independent Restriction of LINE-1 Retrotransposition by APOBEC3H. Sci. Rep. 2017, 7, 10881. [CrossRef] [PubMed]

361. Richardson, S.R.; Narvaiza, I.; Planegger, R.A.; Weitzman, M.D.; Moran, J.V. APOBEC3A Deaminates Transiently Exposed Single-Strand DNA during LINE-1 Retrotransposition. eLife 2014, 3, e02008. [CrossRef]

362. Horn, A.V.; Klawitter, S.; Held, U.; Berger, A.; Vasudevan, A.A.J.; Bock, A.; Hofmann, H.; Hanschmann, K.-M.O.; Trösemeier, J.-H.; Flory, E.; et al. Human LINE-1 Restriction by APOBEC3C Is Deaminase Independent and Mediated by an ORF1p Interaction That Affects LINE Reverse Transcriptase Activity. Nucleic Acids Res. 2014, 42, 396-416. [CrossRef] [PubMed]

363. Liang, W.; Xu, J.; Yuan, W.; Song, X.; Zhang, J.; Wei, W.; Yu, X.-F.; Yang, Y. APOBEC3DE Inhibits LINE-1 Retrotransposition by Interacting with ORF1p and Influencing LINE Reverse Transcriptase Activity. PLoS ONE 2016, 11, e0157220. [CrossRef] [PubMed]

364. Pak, V.; Heidecker, G.; Pathak, V.K.; Derse, D. The Role of Amino-Terminal Sequences in Cellular Localization and Antiviral Activity of APOBEC3B. J. Virol. 2011, 85, 8538-8547. [CrossRef]

365. Salamango, D.J.; McCann, J.L.; Demir, Ö.; Brown, W.L.; Amaro, R.E.; Harris, R.S. APOBEC3B Nuclear Localization Requires Two Distinct N-terminal Domain Surfaces. J. Mol. Biol. 2018, 430, 2695-2708. [CrossRef]

366. MacDuff, D.A.; Demorest, Z.L.; Harris, R.S. AID Can Restrict L1 Retrotransposition Suggesting a Dual Role in Innate and Adaptive Immunity. Nucleic Acids Res. 2009, 37, 1854-1867. [CrossRef]

367. Orecchini, E.; Doria, M.; Antonioni, A.; Galardi, S.; Ciafrè, S.A.; Frassinelli, L.; Mancone, C.; Montaldo, C.; Tripodi, M.; Michienzi, A. ADAR1 Restricts LINE-1 Retrotransposition. Nucleic Acids Res. 2017, 45, 155-168. [CrossRef]

368. Frassinelli, L.; Orecchini, E.; Al-Wardat, S.; Tripodi, M.; Mancone, C.; Doria, M.; Galardi, S.; Ciafrè, S.A.; Michienzi, A. The RNA Editing Enzyme ADAR2 Restricts L1 Mobility. RNA Biol. 2021, 1-13. [CrossRef] [PubMed]

369. Schumann, G.G.; Gogvadze, E.V.; Osanai-Futahashi, M.; Kuroki, A.; Münk, C.; Fujiwara, H.; Ivics, Z.; Buzdin, A.A. Unique Functions of Repetitive Transcriptomes. Int. Rev. Cell Mol. Biol. 2010, 285, 115-188. [CrossRef]

370. Coin, F.; Marinoni, J.C.; Rodolfo, C.; Fribourg, S.; Pedrini, A.M.; Egly, J.M. Mutations in the XPD Helicase Gene Result in XP and TTD Phenotypes, Preventing Interaction between XPD and the P44 Subunit of TFIIH. Nat. Genet. 1998, 20, 184-188. [CrossRef] [PubMed]

371. Lehmann, A.R.; McGibbon, D.; Stefanini, M. Xeroderma Pigmentosum. Orphanet. J. Rare Dis. 2011, 6, 70. [CrossRef]

372. Laugel, V. Cockayne Syndrome: The Expanding Clinical and Mutational Spectrum. Mech. Ageing Dev. 2013, 134, 161-170. [CrossRef] [PubMed]

373. Shiloh, Y. ATM (Ataxia Telangiectasia Mutated): Expanding Roles in the DNA Damage Response and Cellular Homeostasis. Biochem. Soc. Trans. 2001, 29, 661-666. [CrossRef] [PubMed]

374. Stracker, T.H.; Roig, I.; Knobel, P.A.; Marjanović, M. The ATM Signaling Network in Development and Disease. Front. Genet. 2013, 4, 37. [CrossRef] [PubMed]

375. Ceccaldi, R.; Sarangi, P.; D’Andrea, A.D. The Fanconi Anaemia Pathway: New Players and New Functions. Nat. Rev. Mol. Cell. Biol. 2016, 17, 337-349. [CrossRef] [PubMed]

376. Brégnard, C.; Guerra, J.; Déjardin, S.; Passalacqua, F.; Benkirane, M.; Laguette, N. Upregulated LINE-1 Activity in the Fanconi Anemia Cancer Susceptibility Syndrome Leads to Spontaneous Pro-Inflammatory Cytokine Production. EBioMedicine 2016, 8 , 184-194. [CrossRef] [PubMed]

377. Ariumi, Y.; Kawano, K.; Yasuda-Inoue, M.; Kuroki, M.; Fukuda, H.; Siddiqui, R.; Turelli, P.; Tateishi, S. DNA Repair Protein Rad18 Restricts LINE-1 Mobility. Sci. Rep. 2018, 8, 15894. [CrossRef] [PubMed]

378. Watanabe, K.; Tateishi, S.; Kawasuji, M.; Tsurimoto, T.; Inoue, H.; Yamaizumi, M. Rad18 Guides Poleta to Replication Stalling Sites through Physical Interaction and PCNA Monoubiquitination. EMBO J. 2004, 23, 3886-3896. [CrossRef] [PubMed]

379. Mulder, L.C.F.; Chakrabarti, L.A.; Muesing, M.A. Interaction of HIV-1 Integrase with DNA Repair Protein HRad18. J. Biol. Chem. 2002, 277, 27489-27493. [CrossRef]

380. Lloyd, A.G.; Tateishi, S.; Bieniasz, P.D.; Muesing, M.A.; Yamaizumi, M.; Mulder, L.C.F. Effect of DNA Repair Protein Rad18 on Viral Infection. PLoS Pathog. 2006, 2, e40. [CrossRef]

381. Harris, C.R.; Dewan, A.; Zupnick, A.; Normart, R.; Gabriel, A.; Prives, C.; Levine, A.J.; Hoh, J. P53 Responsive Elements in Human Retrotransposons. Oncogene 2009, 28, 3857-3865. [CrossRef] [PubMed]

382. Wylie, A.; Jones, A.E.; D’Brot, A.; Lu, W.-J.; Kurtz, P.; Moran, J.V.; Rakheja, D.; Chen, K.S.; Hammer, R.E.; Comerford, S.A.; et al. P53 Genes Function to Restrain Mobile Elements. Genes Dev. 2016, 30, 64-77. [CrossRef]

383. Tiwari, B.; Jones, A.E.; Caillet, C.J.; Das, S.; Royer, S.K.; Abrams, J.M. P53 Directly Represses Human LINE1 Transposons. Genes Dev. 2020, 34, 1439-1451. [CrossRef] [PubMed]

384. Zaytseva, O.; Kim, N.-H.; Quinn, L.M. MYC in Brain Development and Cancer. Int. J. Mol. Sci. 2020, 21, 7742. [CrossRef]

385. Sun, X.; Wang, X.; Tang, Z.; Grivainis, M.; Kahler, D.; Yun, C.; Mita, P.; Fenyö, D.; Boeke, J.D. Transcription Factor Profiling Reveals Molecular Choreography and Key Regulators of Human Retrotransposon Expression. Proc. Natl. Acad. Sci. USA 2018, 115, E5526-E5535. [CrossRef] [PubMed] 
386. Briggs, E.M.; Mita, P.; Sun, X.; Ha, S.; Vasilyev, N.; Leopold, Z.R.; Nudler, E.; Boeke, J.D.; Logan, S.K. Unbiased Proteomic Mapping of the LINE-1 Promoter Using CRISPR Cas9. Mob. DNA 2021, 12, 21. [CrossRef]

387. Yang, N.; Zhang, L.; Zhang, Y.; Kazazian, H.H. An Important Role for RUNX3 in Human L1 Transcription and Retrotransposition. Nucleic Acids Res. 2003, 31, 4929-4940. [CrossRef]

388. Tchénio, T.; Casella, J.F.; Heidmann, T. Members of the SRY Family Regulate the Human LINE Retrotransposons. Nucleic Acids Res. 2000, 28, 411-415. [CrossRef]

389. Orqueda, A.J.; Gatti, C.R.; Ogara, M.F.; Falzone, T.L. SOX-11 Regulates LINE-1 Retrotransposon Activity during Neuronal Differentiation. FEBS Lett. 2018, 592, 3708-3719. [CrossRef] [PubMed]

390. Kuwabara, T.; Hsieh, J.; Muotri, A.; Yeo, G.; Warashina, M.; Lie, D.C.; Moore, L.; Nakashima, K.; Asashima, M.; Gage, F.H. Wnt-Mediated Activation of NeuroD1 and Retro-Elements during Adult Neurogenesis. Nat. Neurosci. 2009, 12, $1097-1105$. [CrossRef]

391. Xiang, Y.; Yan, K.; Zheng, Q.; Ke, H.; Cheng, J.; Xiong, W.; Shi, X.; Wei, L.; Zhao, M.; Yang, F.; et al. Histone Demethylase KDM4B Promotes DNA Damage by Activating Long Interspersed Nuclear Element-1. Cancer Res. 2019, 79, 86-98. [CrossRef] [PubMed]

392. Fu, L.; Chen, L.; Yang, J.; Ye, T.; Chen, Y.; Fang, J. HIF-1 $\alpha$-Induced Histone Demethylase JMJD2B Contributes to the Malignant Phenotype of Colorectal Cancer Cells via an Epigenetic Mechanism. Carcinogenesis 2012, 33, 1664-1673. [CrossRef]

393. Wilson, C.; Qiu, L.; Hong, Y.; Karnik, T.; Tadros, G.; Mau, B.; Ma, T.; Mu, Y.; New, J.; Louie, R.J.; et al. The Histone Demethylase KDM4B Regulates Peritoneal Seeding of Ovarian Cancer. Oncogene 2017, 36, 2565-2576. [CrossRef] [PubMed]

394. Li, W.; Zhao, L.; Zang, W.; Liu, Z.; Chen, L.; Liu, T.; Xu, D.; Jia, J. Histone Demethylase JMJD2B Is Required for Tumor Cell Proliferation and Survival and Is Overexpressed in Gastric Cancer. Biochem. Biophys. Res. Commun. 2011, 416, 372-378. [CrossRef] [PubMed]

395. Bernardo, G.M.; Keri, R.A. FOXA1: A Transcription Factor with Parallel Functions in Development and Cancer. Biosci. Rep. 2012, 32, 113-130. [CrossRef] [PubMed]

396. Coppé, J.-P.; Desprez, P.-Y.; Krtolica, A.; Campisi, J. The Senescence-Associated Secretory Phenotype: The Dark Side of Tumor Suppression. Annu. Rev. Pathol. 2010, 5, 99-118. [CrossRef]

397. Xu, H.; Yan, Y.; Deb, S.; Rangasamy, D.; Germann, M.; Malaterre, J.; Eder, N.C.; Ward, R.L.; Hawkins, N.J.; Tothill, R.W.; et al Cohesin Rad21 Mediates Loss of Heterozygosity and Is Upregulated via Wnt Promoting Transcriptional Dysregulation in Gastrointestinal Tumors. Cell Rep. 2014, 9, 1781-1797. [CrossRef]

398. Ramos, K.S.; Moore, S.; Runge, I.; Tavera-Garcia, M.A.; Cascone, I.; Courty, J.; Reyes-Reyes, E.M. The Nucleolin Antagonist N6L Inhibits LINE1 Retrotransposon Activity in Non-Small Cell Lung Carcinoma Cells. J. Cancer 2020, 11, 733-740. [CrossRef]

399. Jiang, J.-C.; Rothnagel, J.A.; Upton, K.R. Widespread Exaptation of L1 Transposons for Transcription Factor Binding in Breast Cancer. Int. J. Mol. Sci. 2021, 22, 5625. [CrossRef]

400. Jacob-Hirsch, J.; Eyal, E.; Knisbacher, B.A.; Roth, J.; Cesarkas, K.; Dor, C.; Farage-Barhom, S.; Kunik, V.; Simon, A.J.; Gal, M.; et al. Whole-Genome Sequencing Reveals Principles of Brain Retrotransposition in Neurodevelopmental Disorders. Cell Res. 2018, 28, 187-203. [CrossRef]

401. Bundo, M.; Toyoshima, M.; Okada, Y.; Akamatsu, W.; Ueda, J.; Nemoto-Miyauchi, T.; Sunaga, F.; Toritsuka, M.; Ikawa, D.; Kakita, A.; et al. Increased L1 Retrotransposition in the Neuronal Genome in Schizophrenia. Neuron 2014, 81, 306-313. [CrossRef] [PubMed]

402. Doyle, G.A.; Crist, R.C.; Karatas, E.T.; Hammond, M.J.; Ewing, A.D.; Ferraro, T.N.; Hahn, C.-G.; Berrettini, W.H. Analysis of LINE-1 Elements in DNA from Postmortem Brains of Individuals with Schizophrenia. Neuropsychopharmacology 2017, 42, 2602-2611. [CrossRef]

403. Liu, X.; Shimada, T.; Otowa, T.; Wu, Y.-Y.; Kawamura, Y.; Tochigi, M.; Iwata, Y.; Umekage, T.; Toyota, T.; Maekawa, M.; et al. Genome-Wide Association Study of Autism Spectrum Disorder in the East Asian Populations. Autism. Res. 2016, 9, 340-349. [CrossRef] [PubMed]

404. Lee, E.B.; Lee, V.M.-Y.; Trojanowski, J.Q. Gains or Losses: Molecular Mechanisms of TDP43-Mediated Neurodegeneration. Nat. Rev. Neurosci. 2011, 13, 38-50. [CrossRef] [PubMed]

405. Neumann, M.; Sampathu, D.M.; Kwong, L.K.; Truax, A.C.; Micsenyi, M.C.; Chou, T.T.; Bruce, J.; Schuck, T.; Grossman, M.; Clark, C.M.; et al. Ubiquitinated TDP-43 in Frontotemporal Lobar Degeneration and Amyotrophic Lateral Sclerosis. Science 2006, 314, 130-133. [CrossRef] [PubMed]

406. Amador-Ortiz, C.; Lin, W.-L.; Ahmed, Z.; Personett, D.; Davies, P.; Duara, R.; Graff-Radford, N.R.; Hutton, M.L.; Dickson, D.W. TDP-43 Immunoreactivity in Hippocampal Sclerosis and Alzheimer's Disease. Ann. Neurol. 2007, 61, 435-445. [CrossRef]

407. Nakashima-Yasuda, H.; Uryu, K.; Robinson, J.; Xie, S.X.; Hurtig, H.; Duda, J.E.; Arnold, S.E.; Siderowf, A.; Grossman, M.; Leverenz, J.B.; et al. Co-Morbidity of TDP-43 Proteinopathy in Lewy Body Related Diseases. Acta Neuropathol. 2007, 114, 221-229. [CrossRef]

408. Schwab, C.; Arai, T.; Hasegawa, M.; Yu, S.; McGeer, P.L. Colocalization of Transactivation-Responsive DNA-Binding Protein 43 and Huntingtin in Inclusions of Huntington Disease. J. Neuropathol. Exp. Neurol. 2008, 67, 1159-1165. [CrossRef]

409. Weihl, C.C.; Temiz, P.; Miller, S.E.; Watts, G.; Smith, C.; Forman, M.; Hanson, P.I.; Kimonis, V.; Pestronk, A. TDP-43 Accumulation in Inclusion Body Myopathy Muscle Suggests a Common Pathogenic Mechanism with Frontotemporal Dementia. J. Neurol. Neurosurg. Psychiatry 2008, 79, 1186-1189. [CrossRef] 
410. Bose, J.K.; Huang, C.-C.; Shen, C.-K.J. Regulation of Autophagy by Neuropathological Protein TDP-43. J. Biol. Chem. 2011, 286, 44441-44448. [CrossRef]

411. Mitra, J.; Guerrero, E.N.; Hegde, P.M.; Liachko, N.F.; Wang, H.; Vasquez, V.; Gao, J.; Pandey, A.; Taylor, J.P.; Kraemer, B.C.; et al. Motor Neuron Disease-Associated Loss of Nuclear TDP-43 Is Linked to DNA Double-Strand Break Repair Defects. Proc. Natl. Acad. Sci. USA 2019, 116, 4696-4705. [CrossRef]

412. Liu, E.Y.; Russ, J.; Cali, C.P.; Phan, J.M.; Amlie-Wolf, A.; Lee, E.B. Loss of Nuclear TDP-43 Is Associated with Decondensation of LINE Retrotransposons. Cell Rep. 2019, 27, 1409-1421.e6. [CrossRef]

413. Morera, A.A.; Ahmed, N.S.; Schwartz, J.C. TDP-43 Regulates Transcription at Protein-Coding Genes and Alu Retrotransposons. Biochim. Biophys. Acta Gene Regul. Mech. 2019, 1862, 194434. [CrossRef] [PubMed]

414. Pereira, G.C.; Sanchez, L.; Schaughency, P.M.; Rubio-Roldán, A.; Choi, J.A.; Planet, E.; Batra, R.; Turelli, P.; Trono, D.; Ostrow, L.W.; et al. Properties of LINE-1 Proteins and Repeat Element Expression in the Context of Amyotrophic Lateral Sclerosis. Mob. DNA 2018, 9, 35. [CrossRef]

415. Hadlock, K.G.; Miller, R.G.; Jin, X.; Yu, S.; Reis, J.; Mass, J.; Gelinas, D.; Zhang, J.; McGrath, M.S. Elevated Rates of Antibody Reactivity to HML-2/HERV-K but Not Other Endogenous Retroviruses in ALS. Neurology 2004, 5, A37-A38.

416. Douville, R.; Liu, J.; Rothstein, J.; Nath, A. Identification of Active Loci of a Human Endogenous Retrovirus in Neurons of Patients with Amyotrophic Lateral Sclerosis. Ann. Neurol. 2011, 69, 141-151. [CrossRef] [PubMed]

417. Sun, W.; Samimi, H.; Gamez, M.; Zare, H.; Frost, B. Pathogenic Tau-Induced PiRNA Depletion Promotes Neuronal Death through Transposable Element Dysregulation in Neurodegenerative Tauopathies. Nat. Neurosci. 2018, 21, 1038-1048. [CrossRef]

418. Guo, C.; Jeong, H.-H.; Hsieh, Y.-C.; Klein, H.-U.; Bennett, D.A.; De Jager, P.L.; Liu, Z.; Shulman, J.M. Tau Activates Transposable Elements in Alzheimer's Disease. Cell Rep. 2018, 23, 2874-2880. [CrossRef] [PubMed]

419. Ittner, L.M.; Götz, J. Amyloid- $\beta$ and Tau-a Toxic Pas de Deux in Alzheimer's Disease. Nat. Rev. Neurosci. 2011, 12, 65-72. [CrossRef]

420. Rüb, U.; Stratmann, K.; Heinsen, H.; Seidel, K.; Bouzrou, M.; Korf, H.-W. Alzheimer's Disease: Characterization of the Brain Sites of the Initial Tau Cytoskeletal Pathology Will Improve the Success of Novel Immunological Anti-Tau Treatment Approaches. J. Alzheimers Dis. 2017, 57, 683-696. [CrossRef] [PubMed]

421. Weingarten, M.D.; Lockwood, A.H.; Hwo, S.Y.; Kirschner, M.W. A Protein Factor Essential for Microtubule Assembly. Proc. Natl. Acad. Sci. USA 1975, 72, 1858-1862. [CrossRef] [PubMed]

422. Nizynski, B.; Dzwolak, W.; Nieznanski, K. Amyloidogenesis of Tau Protein. Protein Sci. 2017, 26, 2126-2150. [CrossRef] [PubMed]

423. Ittner, A.; Ittner, L.M. Dendritic Tau in Alzheimer's Disease. Neuron 2018, 99, 13-27. [CrossRef]

424. Hayflick, S.J.; Kurian, M.A.; Hogarth, P. Neurodegeneration with Brain Iron Accumulation. Handb. Clin. Neurol. 2018, 147, 293-305. [CrossRef]

425. Stanga, S.; Caretto, A.; Boido, M.; Vercelli, A. Mitochondrial Dysfunctions: A Red Thread across Neurodegenerative Diseases. Int. J. Mol. Sci. 2020, 21, 3719. [CrossRef]

426. La Morgia, C.; Maresca, A.; Caporali, L.; Valentino, M.L.; Carelli, V. Mitochondrial Diseases in Adults. J. Intern Med. 2020, 287, 592-608. [CrossRef]

427. Missiroli, S.; Genovese, I.; Perrone, M.; Vezzani, B.; Vitto, V.A.M.; Giorgi, C. The Role of Mitochondria in Inflammation: From Cancer to Neurodegenerative Disorders. J. Clin. Med. 2020, 9, 740. [CrossRef]

428. Baeken, M.W.; Moosmann, B.; Hajieva, P. Retrotransposon Activation by Distressed Mitochondria in Neurons. Biochem. Biophys. Res. Commun. 2020, 525, 570-575. [CrossRef]

429. Giorgi, G.; Marcantonio, P.; Del Re, B. LINE-1 Retrotransposition in Human Neuroblastoma Cells Is Affected by Oxidative Stress. Cell Tissue Res. 2011, 346, 383-391. [CrossRef] [PubMed]

430. Whongsiri, P.; Pimratana, C.; Wijitsettakul, U.; Sanpavat, A.; Jindatip, D.; Hoffmann, M.J.; Goering, W.; Schulz, W.A.; Boonla, C. Oxidative Stress and LINE-1 Reactivation in Bladder Cancer Are Epigenetically Linked through Active Chromatin Formation. Free Radic Biol. Med. 2019, 134, 419-428. [CrossRef] [PubMed]

431. Yang, T.-C.; Wu, P.-C.; Chung, I.-F.; Jiang, J.-H.; Fann, M.-J.; Kao, L.-S. Cell Death Caused by the Synergistic Effects of Zinc and Dopamine Is Mediated by a Stress Sensor Gene Gadd45b-Implication in the Pathogenesis of Parkinson's Disease. J. Neurochem. 2016, 139, 120-133. [CrossRef] [PubMed]

432. Ravel-Godreuil, C.; Massiani-Beaudoin, O.; Mailly, P.; Prochiantz, A.; Joshi, R.L.; Fuchs, J. Perturbed DNA Methylation by Gadd45b Induces Chromatin Disorganization, DNA Strand Breaks and Dopaminergic Neuron Death. iScience 2021, $24,102756$. [CrossRef] [PubMed] 